Florida International University FIU Digital Commons

\title{
Preposition Stranding in Heritage Speakers of Brazilian Portuguese
}

Simone H. de Lemos

sbhlemos@yahoo.com

DOI: $10.25148 /$ etd.FI13080701

Follow this and additional works at: https://digitalcommons.fiu.edu/etd

Part of the First and Second Language Acquisition Commons, and the Syntax Commons

\section{Recommended Citation}

de Lemos, Simone H., "Preposition Stranding in Heritage Speakers of Brazilian Portuguese" (2013). FIU Electronic Theses and Dissertations. 912.

https://digitalcommons.fiu.edu/etd/912 
FLORIDA INTERNATIONAL UNIVERSITY

Miami, Florida

\title{
PREPOSITION STRANDING IN HERITAGE SPEAKERS OF BRAZILIAN
}

PORTUGUESE

\author{
A thesis submitted in partial fulfillment of the \\ requirements for the degree of \\ MASTER OF ARTS \\ in \\ LINGUISTICS \\ by
}

Simone Harmath-de Lemos

2013 


\section{To: Dean Kenneth G. Furton \\ College of Arts and Sciences}

This thesis, written by Simone Harmath-de Lemos, and entitled Preposition Stranding in Heritage Speakers of Brazilian Portuguese, having been approved in respect to style and intellectual content, is referred to you for judgment.

We have read this thesis and recommend that it be approved.

Melissa Baralt

$\begin{array}{r}\hline \text { Melissa Baralt } \\ \hline \text { Phillip Carter }\end{array}$

Ellen Thompson, Major Professor

Date of Defense: April 26, 2013

The thesis of Simone Harmath-de Lemos is approved.

Dean Kenneth G. Furton College of Arts and Sciences

Dean Lakshmi N. Reddi University Graduate School

Florida International University, 2013 


\section{DEDICATION}

To my husband, who taught me that love extends far beyond the frontiers I once envisioned. To my children, who taught me that perseverance and strength mean to move inexorably forward. To my siblings, who have always been and will always be there for me.

To my parents-in-law, who adopted me with open arms. To my parents, who taught me everything. 


\section{ACKNOWLEDGMENTS}

I wish to thank the members of my committee for their continued support and guidance. Their knowledge, thoughtful advice, and patience have been more appreciated than words can describe. Dr. Phillip Carter has taught me that there are two equally fascinating perspectives to linguistics. Dr. Melissa Baralt has taught me to keep in mind that all science should, ideally, become applied science at some point. Finally, although I am cognizant that words are not enough, I wish to thank my major professor, Dr. Ellen Thompson. Her keen intelligence is only matched by her endless good humor, ceaseless patience, and unequalled kindness. Never once I left her office without receiving proficient advice to my research and soothing words to the soul. Her relentless confidence in my abilities was vital for this work to be completed with excellence.

I wish to thank the Linguistics Program and the Department of English for granting the assistantship that has allowed me to conclude my studies. Thanks to the Graduate \& Professional Student Committee, the Department of English and Dr. James Sutton, and the Center for International Business Education \& Research, through Professor Augusta Vono, for funding the trip to present this work. The collection of data from monolingual speakers in Brazil was possible with the support of the Portuguese Program, of the Department of Modern Languages, and of Dr. Pascal Bécel. My warm thanks to Dr. Edivalda Alves Araújo, at Universidade Federal da Bahia in Brazil, for valuable insights on the syntax of Brazilian Portuguese.

Importantly, I wish to thank Professor Augusta Vono, my fiercest supporter, who offered me invaluable opportunities in the Portuguese program throughout this journey. She has offered me continued and uninterested mentorship and friendship. 


\section{ABSTRACT OF THE THESIS \\ PREPOSITION STRANDING IN HERITAGE SPEAKERS OF BRAZILIAN \\ PORTUGUESE \\ by}

Simone Harmath de Lemos

Florida International University, 2013

Miami, Florida

Professor Ellen Thompson, Major Professor

Influential bodies of work in language acquisition studies single out heritage

bilingualism as a discrete acquisition process within the bilingualism continuum. In regards to the acquisition of $\mathrm{WH}-/ \mathrm{QU}$ - interrogatives containing prepositional phrases (PP), the present study examined whether heritage speakers (HS) of Brazilian Portuguese (BP) produce preposition stranding ( $\mathrm{P}$-stranding) constructions in their heritage language, in contrast to monolingual and adult speakers of BP, where prepositions are pied-piped to form the interrogative.

Participants were HS of BP born in the USA and in Brazil, monolinguals, and late bilingual adults. The experiment consisted of an elicited production task and a grammaticality judgment task, both carried out in BP and then in English.

Results showed that HS born in the USA use P-stranding in QU- interrogatives productively and systematically, in contrast to the other three groups. Moreover, no evidence of protracted acquisition was found in this group. No signs of attrition were detected among bilinguals. 


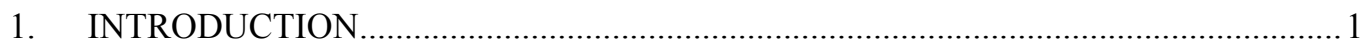

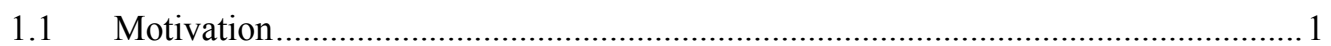

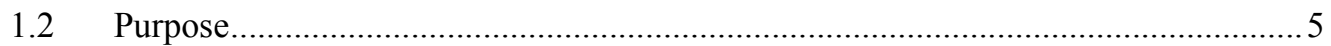

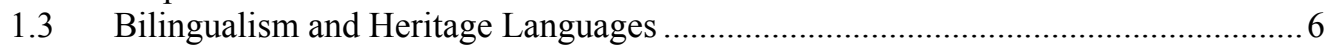

1.4 The Context of Brazilian Immigration to South Florida ........................................... 8

1.5 A Word on Studying Heritage Languages ................................................................ 11

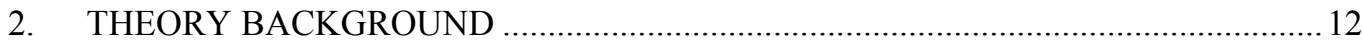

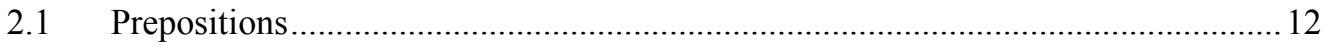

2.1.1 Prepositions and Prepositional Phrases in English........................................ 13

2.1.2 Prepositions and Prepositional Phrases in Portuguese ..................................... 18

2.2 Movement Processes in PPs: Same Question, Different Approaches.......................2 21

2.2.1 A Chronological Account of the Study of Preposition Stranding ....................21

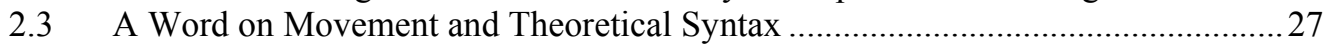

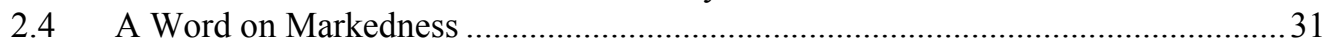

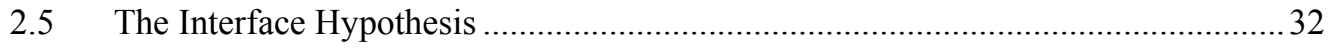

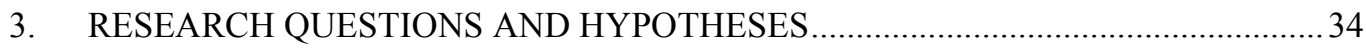

3.1 An Epistemic Account Based on Qualitative Observations....................................... 35

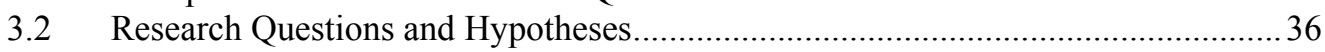

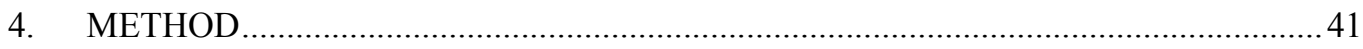

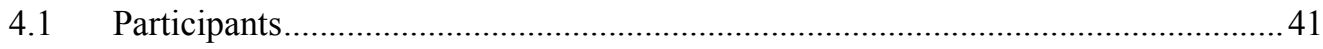

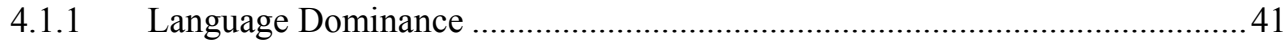

4.1.2 Recruitment and Participants Information ....................................................... 42

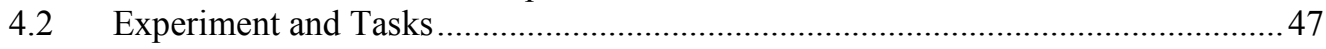

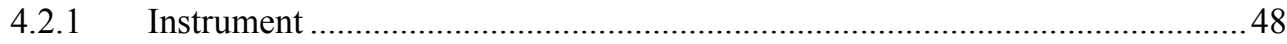

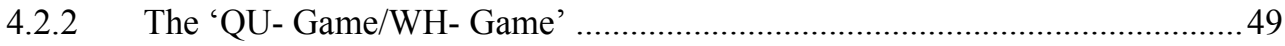

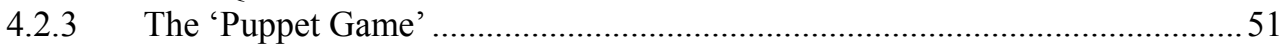

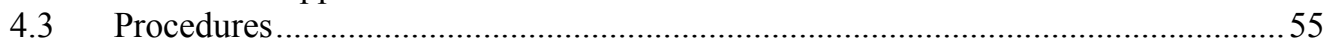

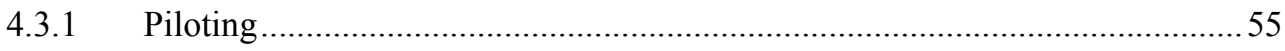

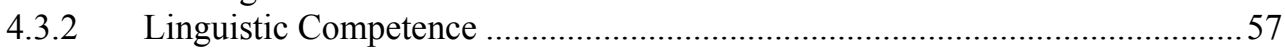

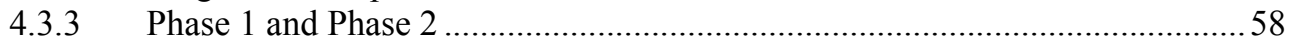

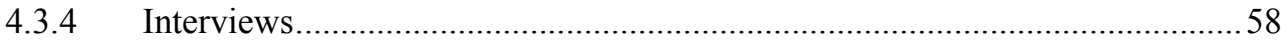

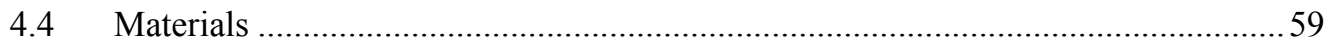

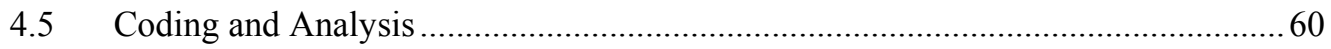

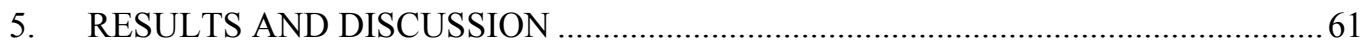

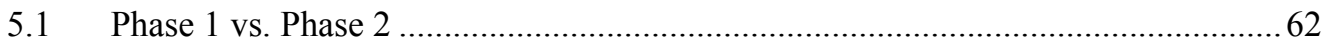

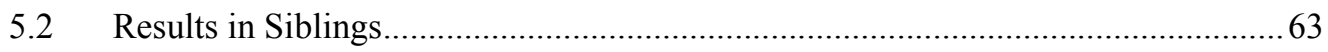

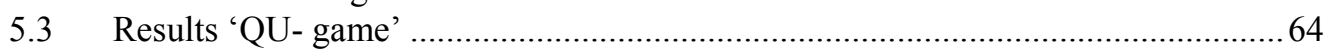

5.3.1 Verbs that Select Prepositional Complements in BP but not in English...........68

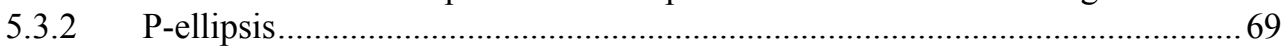

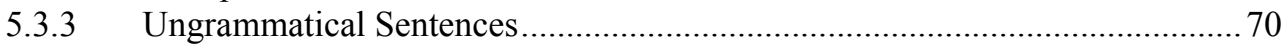

5.4 Results 'Puppet Game' Brazilian Portuguese ........................................................... 73

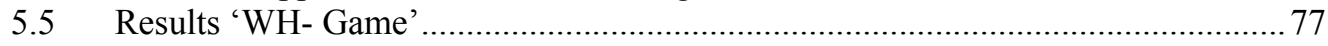

5.6 Results 'Puppet Game’ American English................................................................. 79

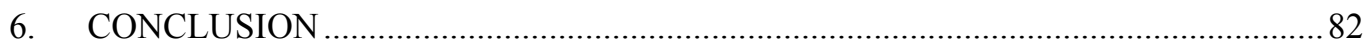

6.1 A Word on Experimental Design and Natural Speech.......................................... 84 


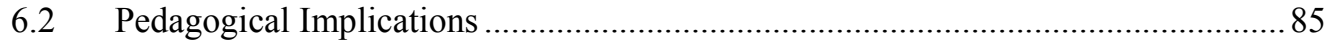

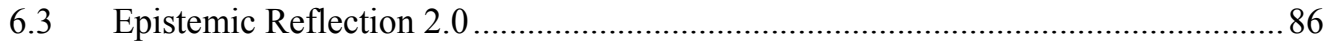

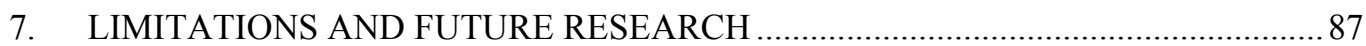

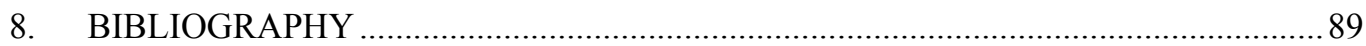

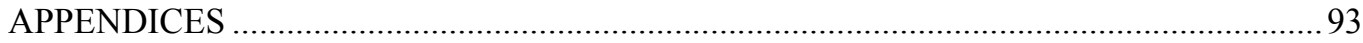




\section{LIST OF TABLES}

TABLE

PAGE

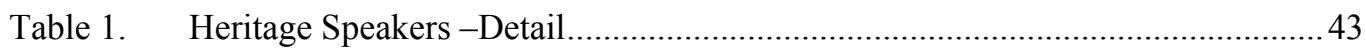

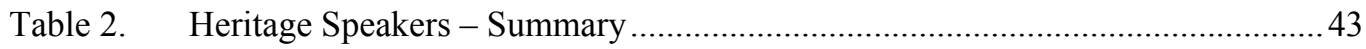

Table 3. Monolingual Control Group - Detail .................................................................

Table 4. Monolingual Control Group - Summary …….................................................. 46

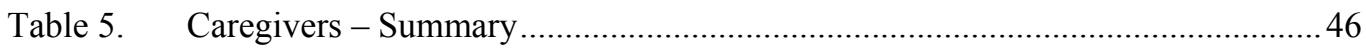

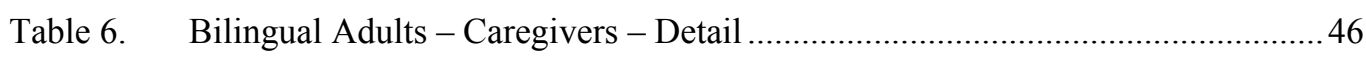

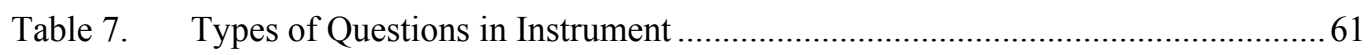

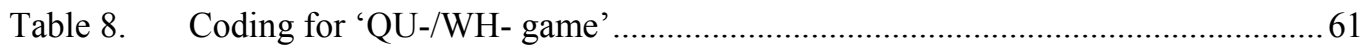

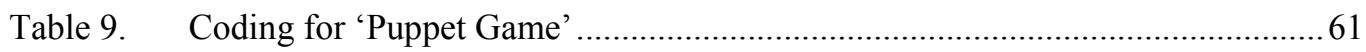

Table 10. Answers in expected pied-piping - HS born in the US ......................................6 64

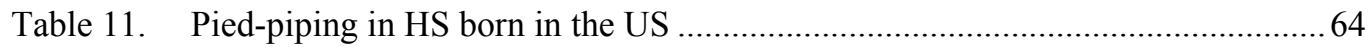

Table 12. Answers in expected pied-piping - HS born in Brazil..........................................6 65

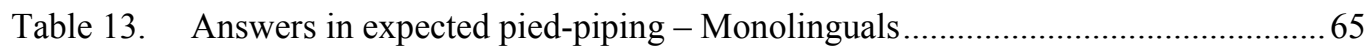

Table 14. Answers in expected pied-piping - Bilingual Caregivers......................................66

Table 15. 'QU- game' - Summary of Answers in Expected Pied-Piping............................67

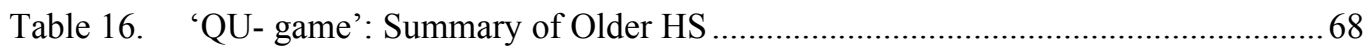

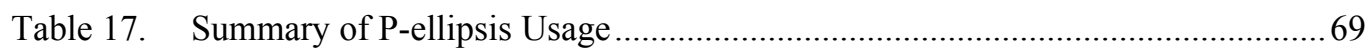

Table 18. Ungrammatical Sentences - HS born in the US ….......................................... 70

Table 19. Ungrammatical Sentences - HS born in Brazil............................................... 71

Table 20. Ungrammatical Sentences - Monolinguals........................................................ 71

Table 21. Ungrammatical Sentences - Caregivers .......................................................... 72

Table 22. Ungrammatical Sentences - Overall ................................................................ 73 


\section{LIST OF FIGURES}

FIGURE

PAGE

Figure 1. Base and Surface Forms of an Interrogative in English......................................2

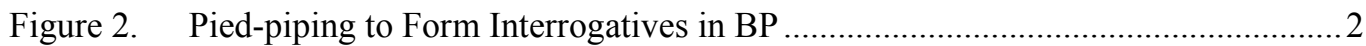

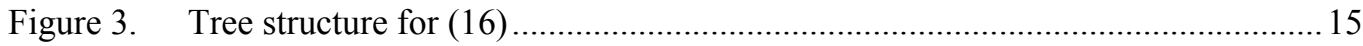

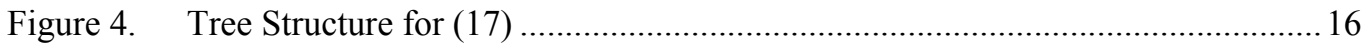

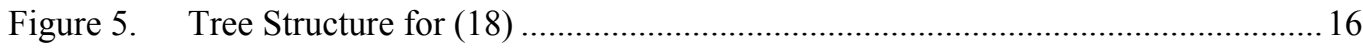

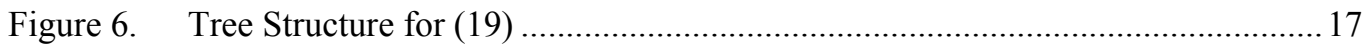

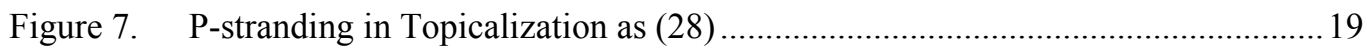

Figure 8. The EST of Transformational-Generative Grammar .........................................29

Figure 9. Classic T-Model of P\&P (Chosmky, 1981) ......................................................... 30

Figure 10. WH- movement: base and surface structures.................................................

Figure 11. PiP in the sentence “A Ana gosta de (o) que." ................................................... 37

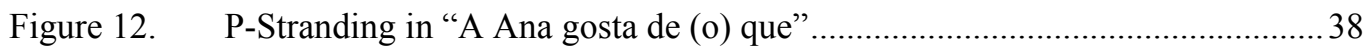

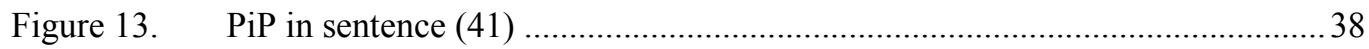

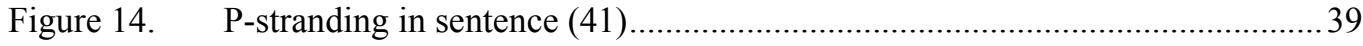

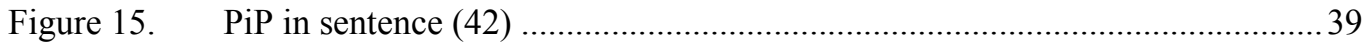

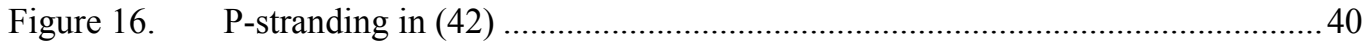

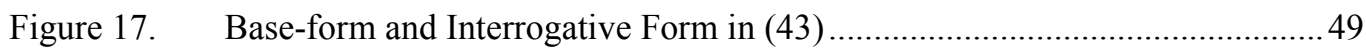

Figure 18. Base-Form and Interrogative Form in (44) ................................................. 49

Figure 19. Base Form and Interrogative Forms in (45) ...............................................50

Figure 20. Base Form and Interrogative Forms in (46) ................................................5

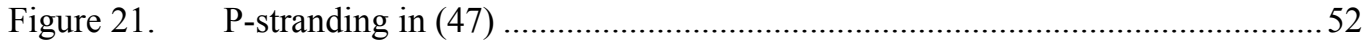

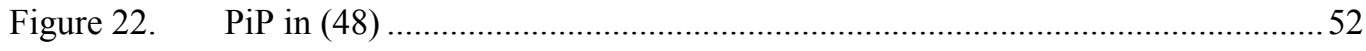

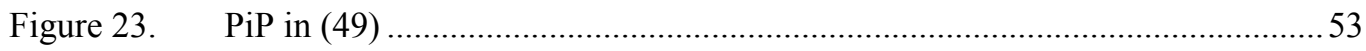

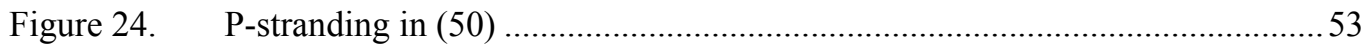

Figure 25. Filler Sentences - WH- movement and in situin (51) and (52) .....................54 
Figure 26. Filler Sentences - QU- movement and in situ in (53) and (54) ......................54

Figure 27. Dudu and Mimi - 'Puppet Game' ................................................................57

Figure 28. Answers in expected pied-piping - HS born in the US ...................................6 64

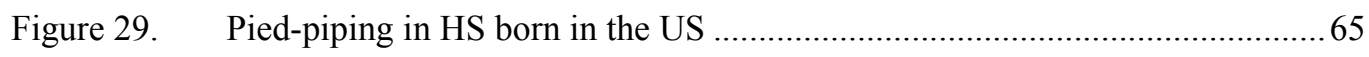

Figure 30. Answers in expected pied-piping - HS born in Brazil....................................65

Figure 31. Answers in expected pied-piping - Monolinguals ...........................................66

Figure 32. Answers in expected pied-piping - Bilingual Caregivers .................................66

Figure 33. Ungrammatical Sentences - HS born in the US …….................................. 71

Figure 34. Ungrammatical Sentences - HS born in Brazil............................................ 71

Figure 35. Ungrammatical Sentences - Monolinguals................................................... 72

Figure 36. Ungrammatical Sentences - Caregivers ...................................................... 72

Figure 37. Answers in Expected Pied-Piping - HS born in the US .................................. 73

Figure 38. Answers in Expected Pied-Piping - HS born in Brazil.................................... 74

Figure 39. Answers in Expected Pied-Piping - Monolinguals.......................................... 74

Figure 40. Answers in Expected Pied-Piping - Caregivers.............................................. 74

Figure 41. Answers in Ungrammatical - HS born in the US .........................................76

Figure 42. Answers in Ungrammatical - HS born in Brazil ......................................... 76

Figure 43. Answers in Ungrammatical - Monolinguals..................................................76

Figure 44. Answers in Ungrammatical - Caregivers ………........................................... 77

Figure 45. Answers in Expected P-stranding - HS born in the US .................................... 78

Figure 46. Answers in Expected P-stranding - HS born in Brazil ....................................78

Figure 47. Answers in Ungrammatical - HS born in the US .........................................79

Figure 48. Answers in Ungrammatical - HS born in Brazil ..........................................79

Figure 49. Answers in Expected P-stranding - HS born in the US ................................... 80

Figure 50. Answers in Expected P-stranding - HS born in Brazil .................................... 80

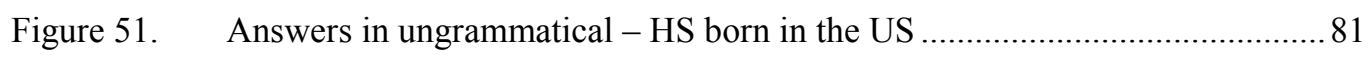

Figure 52. Answers in ungrammatical - HS born in Brazil ............................................ 81 


\section{ABBREVIATIONS AND ACRONYMS}

$1^{\text {st }} \mathrm{S} . \quad$ - first person singular

$1^{\text {st }} \mathrm{Pl}$ - first person plural

$3^{\text {rd }} \mathrm{S} . \quad$ - third person singular

$3^{\text {rd }} \mathrm{Pl} \quad \quad$ - third person plural

A

- adjective

Adv.

- adverb

AdvP

- adverbial phrase

$\mathrm{AE}$

- American English

AOA

- Age of Arrival

AP

- adjectival phrase

$\mathrm{BF}$

- base form

BP

- Brazilian Portuguese

COMP

- complementizer position of a clause

Compl.

- complementizer

D

- determiner

D. A. F

- definite article feminine

D. A. M.

- definite article masculine

Dem. Prox.

- demonstrative pronoun proximity $(\mathrm{BP}=3$-way $)$

DP

- determiner phrase

Dimin.

- Diminutive

EST

- Extended Standard Theory

GB

- Government Binding

HS

- heritage speaker

I. A. F.

- indefinite article feminine

I. A. M.

- indefinite article masculine 


\begin{tabular}{|c|c|}
\hline Infinit. & - Infinitive \\
\hline LF & - logical form \\
\hline $\mathrm{N}$ & - noun \\
\hline NS & - native speaker \\
\hline NNS & - non-native speaker \\
\hline NP & - noun phrase \\
\hline $\mathrm{P}$ & - preposition \\
\hline P-deletion & - preposition/postposition deletion \\
\hline Perf. & - Past Perfective tense \\
\hline $\mathrm{P} \& \mathrm{P}$ & - Principles and Parameters \\
\hline $\mathrm{PF}$ & - phonetic form \\
\hline $\mathrm{PiP}$ & - pied-piping \\
\hline PP & - prepositional phrase \\
\hline Pres. & - Present tense \\
\hline Pron. & - pronoun \\
\hline P-stranding & - preposition/postposition stranding \\
\hline S & - sentence \\
\hline SAE & - Standard American English \\
\hline SLA & - second language acquisition \\
\hline Suppl. & - Suppletive Form (preposition + article \\
\hline $\mathrm{t}_{\mathrm{i}}$ & - trace \\
\hline V & - verb \\
\hline $\mathrm{V}^{*}$ & - complex verb \\
\hline VP & - verb phrase \\
\hline
\end{tabular}




\section{INTRODUCTION}

\subsection{Motivation}

Studies in bilingualism (i.e., Valdés, 2001; Sugisaki \& Snyder, 2002; Sugisaki \& Snyder, 2003; Rodriguez-Mondeñedo, Snyder \& Sugisaki, 2005; Sugisaki \& Snyder, 2005/2006; Iverson, 2006; Sugisaki, 2008; Rothman, 2009; Iverson, 2010), have shown to provide valuable data to both general linguistic theory and to the theory of language acquisition, with implications in pedagogy (i.e., Volpato, Verin \& Cardinaletti, in press, also Jusczyk \& Hohne, 1997; Verin, 2010, both qtd. in Volpato, Verin \& Cardinaletti, in press). Within the spectrum of bilingualism, studies in heritage bilingualism (such as Valdés, 2001; Iverson, 2006; Rothman, 2009; Iverson, 2010) - the context where the speaker's first language (L1) is a minority language, spoken primarily in the home environment (Iverson, 2010) - are of special interest to communities composed of ethnolinguistic minorities, i.e., contexts where immigrant populations are part of the social landscape.

A couple of years ago, my six-year old son asked me: "Mãe, quem que a gente vai no cinema $\underline{\text { com? }}$ ?" ("Mom, who are we going to the movies with?"). I had never heard anyone uttering an interrogative in Portuguese leaving the preposition stranded at the end of the sentence, so it struck me as extremely peculiar.

The 'peculiarity' of the stranded preposition arises from the type of movement targeting the prepositional phrase in the sentence my son uttered: in the minimalist framework of generative syntax, interrogative sentences have a base form similar to a common declarative sentence, as shown in (1) below. In order to form an interrogative, the interrogative particle (a WH- word in English, a QU- word in Portuguese) has to be moved to the left-most periphery of the sentence, as shown in (2). Both structures are illustrated in Figure 1.

(1) Ana talked about which book.

(2) Which book did Ana talk about? 

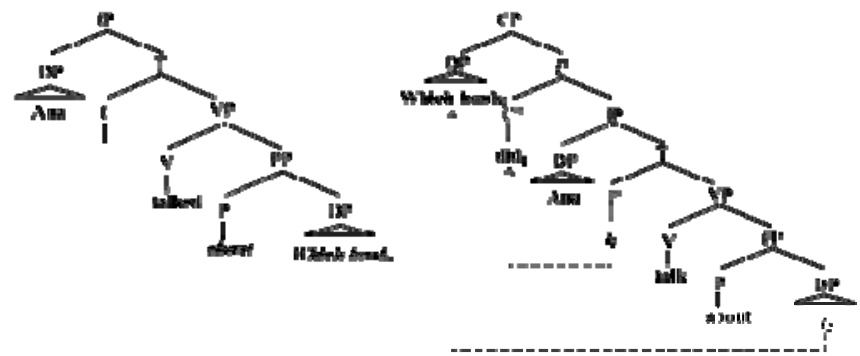

Figure 1. Base and Surface Forms of an Interrogative in English

Different languages, however, behave differently regarding what part of the prepositional phrase (PP) shown in Figure 1 has to be moved to the left periphery of the sentence: while informal registers of American English allow the WH- word (the complement of the PP) to be moved alone, other languages license movement of the entire PP only. Movement of the prepositional complement, shown in sentence (2) above, is called preposition stranding (P-stranding), meaning that the preposition is left "stranded" at the end of the sentence.

Native speakers of Brazilian Portuguese, in contrast to speakers of American English, resort to another type of prepositional phrase movement to form the same type of interrogative in Portuguese, namely, pied-piping (PiP) - which consists in moving the entire PP to the left-most periphery of the interrogative (preposition + complement), as in (3), structure illustrated in Figure 2:
(3) Com quem (que)
a
Andreia brincou?
$\underline{\text { With who }}$ that (Compl.) D. A. F. Andreia played ( ${ }^{\text {rd }}$ S. Perf.)?

With who(m) did Andreia play?

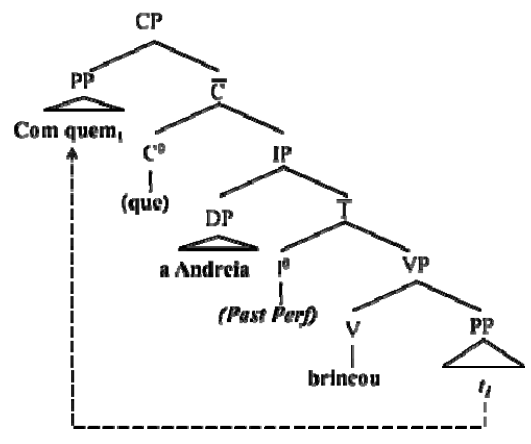

Figure 2. Pied-piping to Form Interrogatives in BP 
It was my perception that my son did pied-pipe the preposition along with the interrogative pronoun before that day, and it seemed to me that after that occurrence he never did so again. At a later date, as I heard Dr. Shana Poplack's closing remarks during her lecture on preposition stranding in Canadian French, at a lecture she gave at Florida International University, I could not help but think that preposition stranding in interrogatives was not an isolated occurrence, restricted to my son's heritage language, it was the norm among the young heritage speakers I knew. In closer observations, it appeared to be the case that preposition stranding (P-stranding, to account for postpositions), also happened in relative clauses, perhaps even more pervasively than in interrogatives. Concurrently, parents of two different children, a six-year old boy (first born), who lives in Sydney, Australia, and a six-year old girl (also first born), who lives locally (South Florida), asked me if I knew why did their children "started saying things like: Que que é isso pra?, or, O brinquedo que eu gosto de é esse." When I asked them what did they mean by "started saying", both responded that the children "did not talk like this before".

Although I do not know any details about the Brazilian community in Sydney, I have lived in South Florida for twelve years now, and I have close ties to the immigrant community - especially to the Brazilian one - in the tri-county area: Miami-Dade, Broward, and Palm Beach counties. During this time, I have never heard an adult speaker of Brazilian Portuguese (BP), immigrant or not, uttering interrogatives or relative clauses leaving the preposition stranded at the end. In addition, these young heritage speakers of BP, to the sheer disappointment of their families, do not communicate with each other in Portuguese, even when they master the language quite well, rendering extremely unlikely any assumptions that this construction is found in the linguistic input these speakers receive in Portuguese.

So, transfer from English seemed to be the adequate answer. Nonetheless, a couple of other issues seemed perplexing: P-stranding is a universally marked construction, attested in only a handful of languages so far - see (Riemsdjik, 1978), (Sugisaki, 2008) and (Sugisaki \&

\footnotetext{
${ }^{1}$ Literally: "What is this for?" and "The toy I like of is this (one)."
} 
Snyder, 2002, 2005/2006) for a more detailed discussion - whereas pied-piping (PiP henceforth) the preposition along with the prepositional phrase is widely common crosslinguistically.

Moreover, while there are numerous features in heritage speakers languages which are not target-like, the absolute majority of them is restricted to lexical items, phonetic and prosodic features, and to morphosyntactic features at the syntax-semantics and syntaxpragmatics interface, in accordance to the Interface Vulnerability Hypothesis (Tsimpli \& Sorace, 2004, 2006; Sorace, 2005, Sorace \& Serratrice, 2009, Müller \& Hulk, 2000) - many related to mood, aspect, and tense, or to agreement in gender and in number (to a much lesser extent). In my qualitative observations, leaving the preposition stranded in the right periphery of the sentence appears to be one of the few non-target instance of structure that these heritage speakers use which appears to be of a purely syntactic nature (although there is argument in the literature supporting the notion that there are no structures which require solely syntactic computations, see Montrul, 2011).

Perhaps what is most enticing about this matter lies beyond the "foreignness" of the construct (in BP) per se: prepositions constitute an intriguing, fascinating syntactic category: in linguistic literature, prepositions play a somewhat ambivalent role, depending on the perspective language is being analyzed from: in language acquisition studies, prepositions are generally seen as closed-class words, function words, or functional categories (Hoff, 2009:224). In theoretic syntax, on the other hand, prepositions are rather regarded as a lexical category, or content words, possessing locative meaning, temporal meaning, directional meaning, etc (Feigenbaum and Kurzon, 2002: 283). Borrowing the words of Smith (Smith, 2002: 83), while describing lexical and functional categories: “...Prepositions are a problem: they appear to belong in both groups". Indeed, prepositions constitute what is probably the most polysemic category in syntactic theory.

Prepositions are also fairly frequent words in natural speech, at least in what concerns English and Romance languages. A number of studies has shown that prepositions account 
for a seizable portion of the total number of words in different corpora of English and Spanish (Girju, 2009).

Interestingly enough, prepositions are the last among all major lexical categories to be acquired in children's speech (Feigenbaum and Kurzon, 2002: 283). Furthermore, there appears to be a specific sequence in the acquisition of prepositions, at least in the acquisition of locative prepositions, that is common to a number of languages studied in Faingold, 2003. According to Faingold, adults learning a second language acquire these prepositions mostly in the same sequence observed in child first language acquisition.

Importantly, prepositions are a source of huge "headaches" to both native speakers and second language learners of English and Romance languages (Girju, 2009: 185), regardless of where the learning process takes place: at school or in a naturalistic environment. They also represent a major source of errors for language learners (Girju, 2009: 185).

\subsection{Purpose}

The main purpose of the present study is to document how heritage speakers of Brazilian Portuguese use prepositional phrases in their heritage language. Specifically, this investigation explores movement processes targeting prepositional phrases, aiming to provide evidence to the fact that, heritage speakers, differently from their monolingual counterparts, and also contrasting with their caregivers - late bilingual adults - resort to P-stranding as the preferred choice of structure when forming QU-interrogatives in Brazilian Portuguese. Moreover, I will search for evidence of systematicity in the manner PP movement is used in these speakers' heritage language.

Additionally, this research study seeks to provide substantial evidence that Pstranding in QU-interrogatives is not part of the Brazilian Portuguese linguistic input heritage speakers receive. 
As a secondary objective, I will look for signs of attrition in children who immigrated to the United States at a later age -6 and older - who despite having undergone the process of sequential bilingualism in childhood, were exposed to a much richer linguistic input in their L1 (Brazilian Portuguese), and who were hence exposed to a second language system (English, their L2), at a much later age. For the purposes of the present investigation, this latter group still qualifies under the umbrella of heritage bilingualism, as BP is spoken solely in the home context.

Lastly, two epistemic reflections were sketched: one - presented in chapter 3 - was constructed prior to the experiment, derived from longitudinal qualitative observations made on the language acquisition process of heritage speakers of Brazilian Portuguese. The second one, presented in chapter 6 , was put together by analyzing the data from this study - still keeping in mind the first reflection - and discussing the findings from the standpoint of three different frameworks of theoretical linguistics. The purpose here is to illustrate how evidence from studies in child language acquisition, specifically from studies in heritage language acquisition, may be invaluable tools in the process of testing new - or established theoretical frameworks within the field of linguistics. Albeit based on both qualitative and quantitative data, these accounts are a pure exercise of philosophy, and they which may be expanded, corroborated, modified, or refuted by future studies in heritage bilingualism.

\subsection{Bilingualism and Heritage Languages}

Borrowing Baetens-Beardsmore's words (1986:1), "Bilingualism as a concept has open-ended semantics". Bilingualism is a broad concept, subject to the influence of countless variables and contexts, which can potentially turn any attempt to narrow its definition into an infelicitous one. Baetens-Beardsmore's words constitute a useful cautionary tale to researchers on the dangers of undertaking investigations on bilingualism too lightly, as discussed in more detail in section 1.5 of this chapter. 
Edwards (2004:7), writes that "everyone is bilingual", suggesting that every adult human being in the world knows, or at least understands, a few words in a foreign language. Paradoxically, one could argue that no one in the world is bilingual. There most probably is not one single individual in this world who knows any two languages in a perfectly balanced, identical manner. Language is also the combination of individual and social experiences, and it is very common that a person learns, for example, to ride a horse or dance ballet 'in French', but to talk to grandparents 'in Spanish, or Portuguese', while the schooling experience might be 'in German, or English'. In short, the possibility that one single person will have balanced linguistic competence in every domain of that person's life, and in all languages the person knows, is certainly immaterial.

Let us not try to define bilingualism then, since "the question, of course, is one of degree" (Edwards, 2004), but to delimit the aspects of the continuum which are relevant to this investigation - namely, that of heritage bilingualism.

Rothman (2009) states that, for a language to be qualified as a heritage language, "it has to be spoken at home, or to be otherwise readily available to young children, and crucially this language is not a dominant language of the larger (national) society". Iverson (2006) adds that a heritage language is, crucially, a minority language in its context. Such is the context of Portuguese in South Florida, so that it qualifies as a heritage language under the umbrella of the concepts laid out above.

Definitions for heritage speaker (HS) can be found in (Valdés, 2001), (Iverson, 2006), and (Rothman, 2009), and among others. As given by Iverson (2006), with relevant modifications to language applied: "Herein, a heritage speaker is one who received naturalistic Spanish Portuguese input (i.e., not formal instruction) in childhood, either as an exclusive L1 or as simultaneous bilingual with English, but was raised in the United States where Spanish Portuguese is a minority language without high with neutral levels of prestige." 
Importantly, he above rendition of Iverson's definition for heritage speakers includes heritage speakers whose language acquisition process fits into Rothman's description of sequential bilingualism in childhood (Rothman, 2009:157), as well as those heritage speakers who fit his characterization of simultaneous bilingualism (Rothman, 2009:157).

In recent years, Sugisaki and colleagues have conducted a series of works (Sugisaki, 2008; Sugisaki \& Snyder, 2005/2006; Rodriguez-Mondeñedo, Snyder \& Sugisaki, 2005; Sugisaki \& Snyder, 2003; Sugisaki \& Snyder, 2002) that demonstrated the importance of child language acquisition studies to serve as source of evidence for theoretical linguistics: it is the belief of the authors that studying heritage speakers' languages and language acquisition processes may prove to be extremely valuable for the field of linguistics as a whole. Central to this stance is the fact that we encounter, in heritage speakers, a language (the heritage language) which, most often than not, has never been subject to interference from the schooling process. Additionally, the literature provides reasonable supporting evidence to the fact that corrective feedback from caregivers alone is, in general, ineffective, not to mention that these speakers do not use the heritage languages in social contexts outside the household, rendering the language in question much less susceptible to sociolinguistic (external) variables. It follows that it must be the case that heritage languages hold the potential of providing researchers with a valuable window into how the brain processes language.

\subsection{The Context of Brazilian Immigration to South Florida}

Before starting to write about Brazilian immigration to South Florida, it is necessary to mention that the picture depicted in the following paragraphs is a portrait of my perception after having lived and worked within this community, for the last 12 years. During these years, I have worked with immigrant families, and with children of immigrants, inside the Palm Beach County School District, and outside, both in community programs designed to teach Portuguese to children of immigrants, and in churches. The work has allowed me to 
meet families who came from a wide spectrum of socioeconomic and immigrational backgrounds.

It follows then, that the information below has to be biased according to personal experience, and that the present chapter is a descriptive account. Nevertheless, I believe it to be a quite accurate description, one gathered after years of experience and careful observation. Although it is not a comprehensive one, it fulfills the purpose of singling out sociolinguistic variables as possible originators of the use of preposition stranding by heritage speakers of Brazilian Portuguese.

I also want to point out to the fact that, when I mention that Brazilian Portuguese has neutral level of prestige in South Florida, and that Brazilian immigrants in South Florida, in general, do not feel that speaking Portuguese is a diminishing factor, socially speaking, these assertions concern language exclusively. It is a well-known fact that Brazilians, both in Brazil and outside, have very low self-esteem, which extends to what Brazilians think about themselves as individuals, to how Brazilians perceive themselves as a people, to what Brazilians think about Brazil, and, consequently, to what Brazilians think about themselves as immigrants. Language however, is something cherished by Brazilians: it is very important to a Brazilian the fact that Portuguese (and not Spanish) is the language of Brazil. In other words, the Portuguese language is an important part of Brazilian identity. Therefore, there is a distinctive line separating issues with self-esteem that Brazilians may have, from linguistic self-esteem.

The overall context of Brazilian immigration in South Florida is such that two generations (which started the influx to United States during the early eighties), constitute the vast majority of the community: one which came to the United States at adult age significantly past early adolescence years - and one comprised by the children of the immigrant generation. Few members of the community are third generation, or the grandchildren of the immigrant generation, most of these are very young children. A number of families immigrated from Brazil with two generations, forming a three-generation family 
in South Florida; however in these families there is only one generation of heritage speakers of Portuguese, as the first two generations came to the United States past adult age, and are considered to be late sequential bilinguals. The information above is important supporting evidence to the assertion that P-stranding is not present in the linguistic input heritage speakers of BP receive, in other words, there is not (yet) an ongoing change in the Portuguese spoken in South Florida in regards to this structure.

As it is the case with immigrant communities throughout the world, it is hard to provide a reliable and accurate headcount of the population. Estimates add to something between 150,000 (the more conservative ones) and 300,000 (claimed to be a more precise figure), Brazilians in Florida, the absolute majority of them concentrated in South Florida. During the last few years, there has been a sizeable number of Brazilians flocking back to Brazil, mostly because of the present instability of the economy worldwide.

Although the social and the immigrational contexts that characterize the Brazilian community in South Florida vary widely, neither the Portuguese language, nor the Brazilian culture - as minority language and minority culture - carry a heavy social stigma. Otherwise stated, despite the fact that South Florida's native population's stance towards Brazilian culture and the Portuguese language is far from homogeneous - ranging from highly favorable to indifferent - overt disapproval of either one is seldom seen, and such cases can be regarded as isolated. Such seems to be the case regardless of the immigrant's legal status or socio-economic background. That is absolutely far from saying that BP might occupy an adstratum position in regards to English: it is still regarded as a minority language, although the overall attitude towards it seems to be that of indifference.

The observations above are of relevance to the present work, since the prestige - or lack thereof - that a minority culture and a minority language enjoy in a given social context, generates what Rosina Lippi-Green calls linguistic insecurity (Lippi-Green, 1997:174-75), and which exerts great influence over both the acquisition process and the maintenance of the heritage (minority) language. 
From the heritage speaker's perspective, the general attitude held towards their Brazilian-American identity and towards the Portuguese language is a positive one, in part because of the overall neutral status the language holds in South Florida's social context, in part because Brazilians are, generally speaking, favorably seen by the locals, and in part because Brazilian families usually form a very tightly-knit nucleus, so that heritage speakers of Portuguese maintain close contact with Brazil and their loved ones in that country.

The considerations made in the previous paragraphs constitute, needless to say, a very superficial and generalized picture of the Brazilian community's status quo in South Florida. Nevertheless, they provide sufficient information for the scope of the present investigation, as they account for possible sources of linguistics input for these heritage speakers, and for issues - or lack thereof - with Brazilian-American identity in South Florida.

\subsection{A Word on Studying Heritage Languages}

The challenge in studying bilingualism lies in the countless variables that can influence the results, which ergo, have to be accounted for. Mishandled variables, or variables unaccounted for, can significantly alter the outcome of an investigation, and since new experiments rapidly build on top of the results of existing investigations, undesirable effects can quickly propagate. It rests upon the researcher, then, the responsibility to try and delineate with accuracy the variables, and the context of the investigation.

Having lived in South Florida's social landscape, and having worked as a volunteer in the school system for so many years, I have learned that heritage speakers are a vulnerable minority, and that research on this topic has the potential of greatly impact this group. The number of parents reporting that 'teachers at school advised them to stop speaking the heritage language with their children at home', or that 'teachers told parents they should not read to their children in any language other than English', is too large to keep track of in this thesis. The many terms used by the scientific community to refer to heritage speakers' language are not exactly flattering, and there exists a pervasive, inherent sense among 
immigrant families that 'there is something wrong with the child's heritage language', sometimes actually with both the dominant and the heritage language. The school system often associates the 'something' families refer to, with the child's overall cognitive abilities.

The simple truth is that much more research is needed in this field before conclusions are drawn, and it might well be the case that 'something wrong' may be just 'something different', or the result of how language is processed by the brain when exposed to more than one linguistics system, in the absence of a richer linguistic input in one of the languages, and in the absence of additional cultural constraints - i.e., schooling, society using what Bourdieu called "the legitimate language" (Bourdieu, 1991).

\section{THEORY BACKGROUND}

\subsection{Prepositions}

Adpositions are words used to express location, manner, time, possession, etc. Some languages, such as English and Romance Languages, place adpositions before their respective complements - in which case they are called prepositions - while other languages, like Japanese (Inoue, 1987), place adpositions after their respective complements - in which case they are called postpositions (Radford, 1997).

Radford defines prepositions as "an invariable word generally used to express location, manner, etc.," (Radford, 1997). Cegalla, in Novíssima Gramática da Língua Portuguesa, states that prepositions are "invariable words that connect a dependent term to a main term, establishing a relationship among both" (Cegalla, 2008).

In what concerns the attempt to define any grammatical category as "a set of elements which have the same value for a given set of grammatical features" (Radford, 1997: 66), the category of prepositions is a lexical category, (universally) described by the following basic binary grammatical feature composition:

$$
\mathbf{P}=[-\mathbf{N},-\mathbf{V},-\mathbf{F}] \quad \text { where: } \quad \mathbf{N}=\text { Nominal Feature } \quad \text { (nominal } / \text { non-nominal) }
$$




$$
\begin{aligned}
& \mathbf{V}=\text { Verbal Feature (verbal/non-verbal) } \\
& \mathbf{F}=\text { Functionality Feature (functors/contentives) }
\end{aligned}
$$

Although a semantic classification of prepositions lies beyond the scope of the present work (for a more detailed discussion on the Semantics of prepositions, see Girju, 2009), it is worthwhile to mention that they are highly polysemic words, that they can be assigned different semantic roles - agent, theme, experiencer, etc., - and that they can be assigned different semantic load: spatial, temporal, manner, purpose, etc.

\subsubsection{Prepositions and Prepositional Phrases in English}

English allows for transitive prepositions - the ones that take a nominal/pronominal complement - and for intransitive prepositions, which do not take any complement (Radford, 1997). The same preposition can function as transitive or intransitive, as seen in (4) and (5), where the prepositions are shown in italics, and their complements are underlined:

(4) Someone is outside the house.

(5) The girls are playing outside.

Intransitive prepositions are generally phonologically identical to transitive prepositions. Emonds (1972, qtd. in Riemsdijk, 1978), argued that particle verbs in English are actually intransitive prepositions.

Transitive prepositions take an object complement, usually in the shape of either a determiner phrase (DP), or a pronominal, as shown in examples (6) and (7) below. Prepositions can also take a couple of other types of complements, such as another prepositional phrase, as exemplified in (8). The combination of the preposition with its complement forms a prepositional phrase (PP).

(6) I am talking [Pp [P about] [NP [D this] [N book]]].

(7) I am talking [pp [p about] [op [pron. him]]].

(8) Ana appeared [pP [P from] [PP [p behind] [DP [the curtains]]]. 
Movement targeting PPs can occur in three types of clauses in English: WHinterrogative clauses, relative clauses, and pseudo-passives, shown in (9), (10), and (11), respectively.

(9) Who are you talking to?

(10) This is the man I was talking to.

(11) You are being pointed at.

Prepositional phrases can undergo two types of movement in English. One of them is pied-piping - the movement of the entire PP, $\mathrm{P}$ plus its complement, into spec-CP position, in order to check strong Q-feature with COMP (the presubject, or complementizer position of a clause) - which is mostly used in formal registers of English, and which is shown in (12) below (Radford, 1997):

(12) $\left[\mathrm{CP}\left[\mathbf{p P}[\mathbf{P}\right.\right.$ To] [o whom] $] \mathrm{i}\left[\mathrm{IP} \ldots\right.$ are you talking $\left.\left.\mathbf{t}_{\mathbf{i}}\right]\right]$ ? (Radford, 1997:279-(37)(a))

The second sort of movement a PP can undergo in English is preposition stranding (P-stranding, to account for postpositions, in languages that have them) - which consists in extracting the complement of the PP out of the phrase and preposing it, leaving P "stranded", as in (13) (Radford, 1997:278- his (35)(a)).

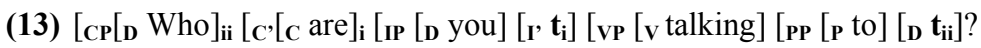

Prepositional phrase movements in WH- clauses is known as WH- movement (movement of the WH- operator), since both types of movement - PiP and P-stranding - are, as afore mentioned, motivated by the fact that the $\mathrm{WH}$ - word has to raise into spec-CP in order to check strong Q-feature with COMP (Radford, 1997).

However, $\mathrm{P}$-stranding is not restricted to $\mathrm{WH}$ - clauses, it also occurs in relative clauses, and in pseudo-passives, as shown in (14), and (15) respectively:

(14) This is [DP the movie $]_{\mathbf{i}}$ I told you [PP about [DP $\left.\left.\mathbf{t}_{\mathbf{i}}\right]\right]$.

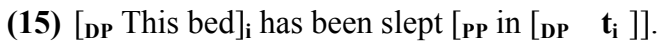


In the sentences above, stranding happens not by means of WH- movement, but by means of DP-movement, Riemsdijk's N"'-movement ( Riemsdijk, 1978). It turns out that stranding a preposition by $\mathrm{WH}-$ movement is possible in a much greater number of instances than stranding a preposition by N"'-movement ( Riemsdijk, 1978).

Preposition stranding is the preferred construction in Standard American English (SAE) - albeit the fact that formal registers of English proscribe its use, displaying a preposition-stranding constraint (Radford, 1997) - and can be quite freely applied, creating the erroneous perception that it can be applied in any case, to any preposition. There are, nevertheless, restrictions, as exemplified in (16), (18), and (19), illustrated in Figure 3, Figure 5, and Figure 6 respectively:

(16) He said [DP pictures [PP of [DP $\mathbf{m y}$ children]]] were all over the house.

a. *[DP Whose children]i did he say [DP pictures [PP of [DP ti ]]] were all over the house?

b. *[PP Of whose children] i did he say [DP pictures [PP ti ]] were all over the house?

c. [DP Pictures [PP of [DP whose children]]] i did he say [DP ti ] were all over the house?

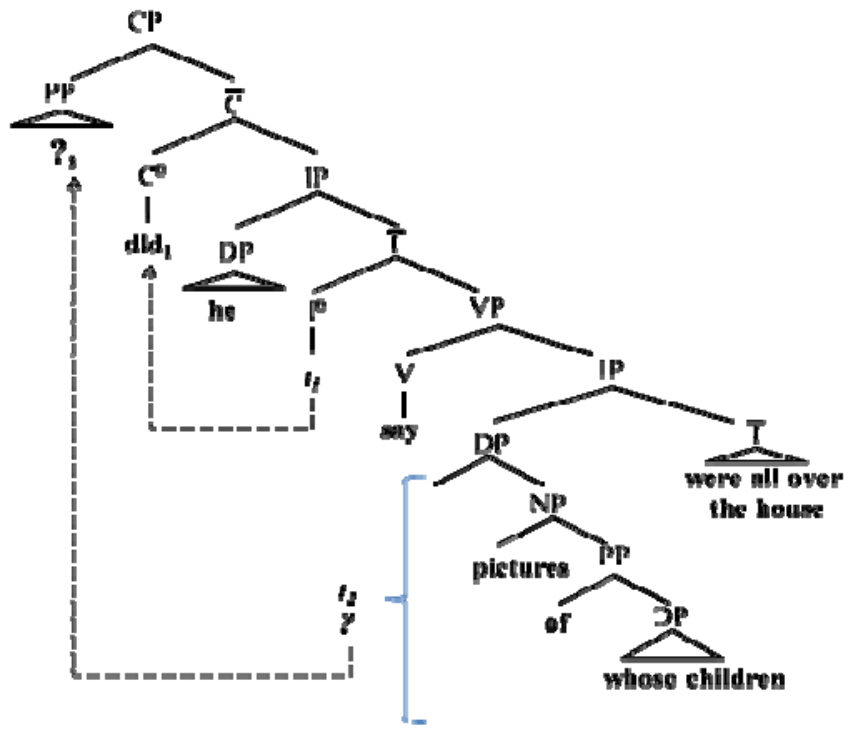

Figure 3. Tree structure for (16)

(17) $\left[_{D P} \text { Whose children }\right]_{i}$ are you taking pictures $\left[_{P P}\right.$ of $\left.\left[_{D P} t_{i}\right]\right]$ ? 


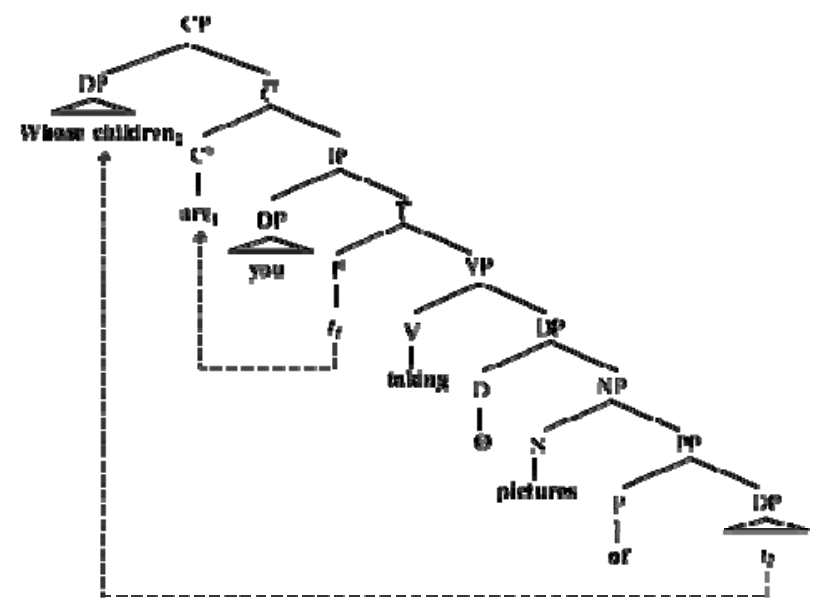

Figure 4. Tree Structure for (17)

(18) Ana is leaving during the second break.

a. *Which break is Ana leaving during?

b. ?During which break is Ana leaving?

c. Ana is leaving during which break?

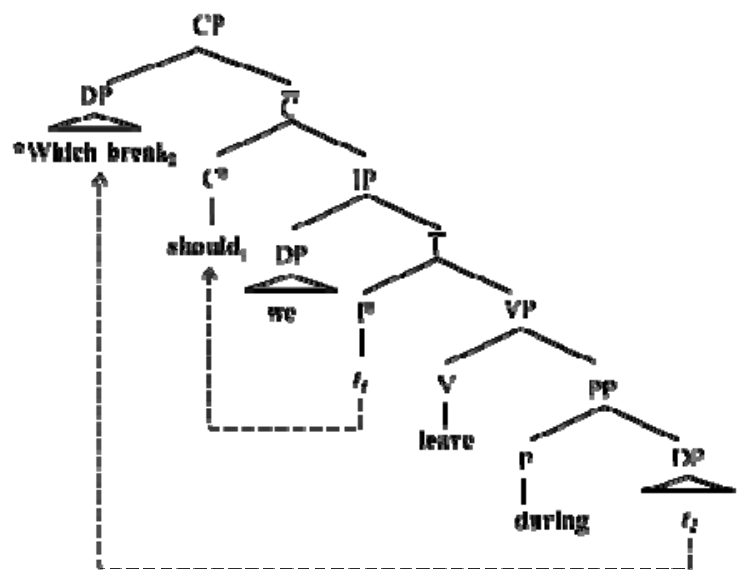

Figure 5. Tree Structure for (18)

(19) They took a shot at him from behind the car

( Riemsdijk, 1978:146-his (34))

a. From behind the car they took a shot at him.

b. *Behind the car they took a shot at him from. 


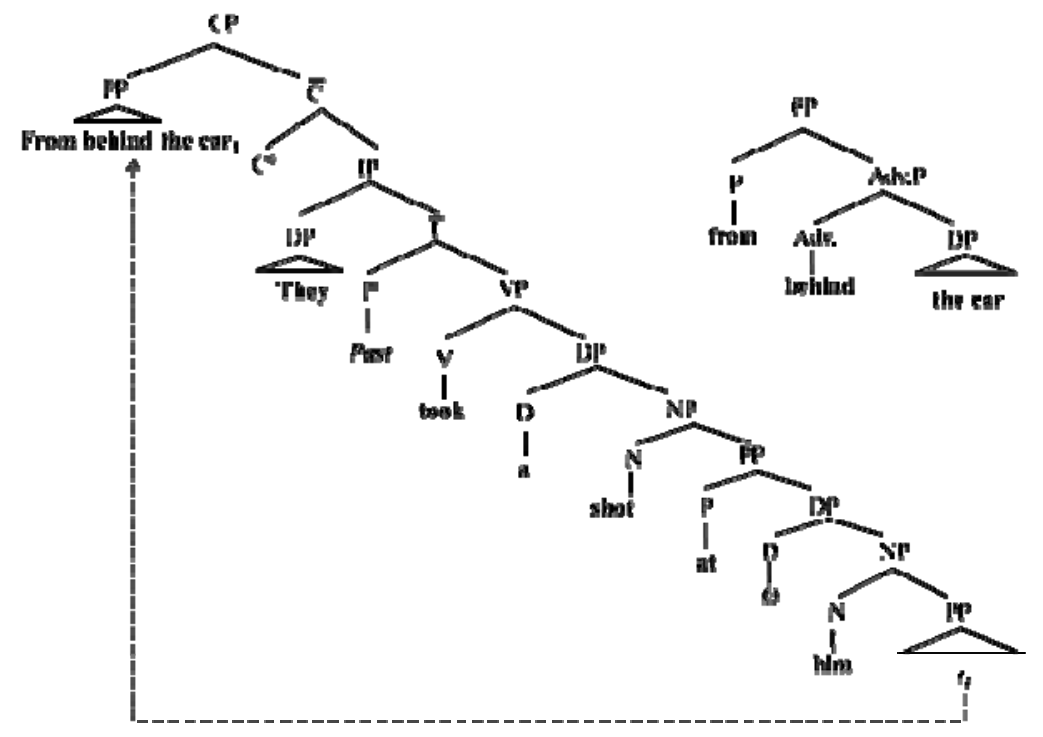

Figure 6. Tree Structure for (19)

In sentence (16), movement of the prepositional phrase would cause the derivation to crash, yielding an ungrammatical sentence: rather the whole determiner phrase (which contains the PP) has to be moved to form an interrogative. Contrastively, in sentence (17) illustrated in Figure 4 - it is perfectly fine to move the PP, leaving the preposition stranded. The reason for the contrast is that English abides to the Condition on Extraction Domains $\boldsymbol{C E D}$ - proposed by Huang 1982 (qtd. in Radford, 1997) - which states that complements are the only types of constituents that allow extraction out of them. In other words, in (16), the DP pictures of whose children is actually the subject of the verb were, whereas in (17), the same DP, pictures of whose children, is the object of the verb taking. Huang's CED argues, then that extraction can only happen from arguments which are in complement position, never in subject position.

Sentences (18) and (19) evince the fact that, even when the PP is the complement of the verb (not the subject), there still are cases where the preposition has to be pied-piped along with its object, be it under WH-movement or under DP-movement.

Lastly, it is important to mention that English also possesses complex prepositions, such as: in spite of, with respect to, except for, among others. 


\subsubsection{Prepositions and Prepositional Phrases in Portuguese}

In BP there are both simple prepositions and prepositional locutions (complex prepositions). The latter usually appear in one of two forms (Cegalla, 2008):

a. ADVERB + SIMPLE PREPOSITION, as in: dentro de (inside of), fora de (outside of), devido a (due to), acima de (above of), abaixo de (below of), etc.

b. ADVERBIAL LOCUTION + SIMPLE PREPOSITION, as in: em cima de (in/on over of), por trás de (for behind of), a favor de (in favor of), de acordo com (of according with/to), etc.

Adverbial locutions (complex adverbs) themselves are of the form SIMPLE PREPOSITION + ADVERB (Cegalla, 2008).

Intransitive prepositions are uncommon in BP, to the best of my knowledge, but some complex prepositions can display intransitivity, as shown by (20) below:

(20) Vá $\quad[$ pP [P em] [advP [Adv frente $]]]$. Go $\left(2^{\text {nd }}\right.$. S. Imp. $) \quad$ [AdvP [Adv ahead]].

\section{OR}

Go $\left(2^{\text {nd }}\right.$. S. Imp. $) \quad$ [AdvP [Adv straight][Adv ahead]].

Go (straight) ahead.

As for transitive prepositions in BP, they too, like their English counterparts, usually take DPs or Pronominals as their complements, occasionally taking other PPs as well, as shown in (21), (22), and (23):

(21) Eu estou falando [PP [p sobre] [NP [D este] [N livro]]].

I am ( $\left({ }^{\text {st }}\right.$ S. Pres.) talking (Gerund) $\left[_{\mathrm{PP}}\left[\mathrm{P}\right.\right.$ about] $\left[_{\mathrm{NP}}\left[\mathrm{D}\right.\right.$ this] $\left[_{\mathrm{N}}\right.$ book $\left.\left.]\right]\right]$.

(22) $\mathrm{Eu}$ estou falando [pp [p d+(Suppl.)] [Dp [Pron. + ele $]]]$. (dele)

I am ( ${ }^{\text {st }}$ S. Pres.) talking (Gerund) [PP $_{\mathrm{P}}$ of (Suppl.)] [DP [Pron. him]I].

(23) A Ana saiu [Pp [p detrás] [Pp [P d+(Suppl.)] [Dp [D as cortinas]]].

D.A. F. Ana left ( $3^{\text {rd }}$ Perf.) [PP [p from behind] [PP [p of (Suppl.)]] [DP [the curtains]]]. 
As a general rule, for all PP movements in BP, the prepositional head has to be piedpiped along with its complements, whether the sentence is a QU- interrogative or a relative clause. Sentences (24) and (25) show instances of PP pied-piping in a QU- interrogative, and in a relative clause, respectively, while (26) and (27) are the ungrammatical counterparts using P-stranding (notice that only the structure of interest is fully described):

(24) $\left[\ldots[\mathbf{p p}[\mathbf{p} \text { Com }] \quad[\mathbf{D} \text { quem }]]_{\mathbf{i}}\right.$ você está falando $\left.\left[\mathbf{p P} \mathbf{t}_{\mathbf{i}}\right] \ldots\right]$ ? $\left[\ldots{ }_{\mathrm{PP}}[\mathrm{P} \text { With }]\right]_{\mathrm{D}}$ who(m) $]_{\mathrm{i}}$ you are $\left(2^{\text {nd }}\right.$ S. Pres. $)$ talking $($ Gerund $\left.)\left[{ }_{\mathrm{PP}} \mathrm{t}_{\mathrm{i}}\right] \ldots\right]$ ?

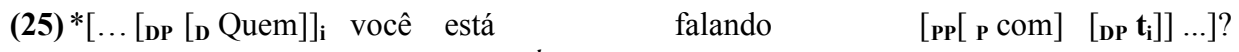
*[... [DP [D Who $]_{\mathrm{i}}$ you are $\left(2^{\text {nd }}\right.$ S. Pres. $)$ talking (Gerund $)\left[_{\mathrm{PP}}\left[\mathrm{P}\right.\right.$ With] $\left.\left[_{\mathrm{DP}} \mathrm{t}_{\mathrm{i}}\right] \ldots \ldots\right]$ ?

(26) A pessoa com quem a Maria falou. (Salles, 2001-her (1)) (D. A. F.) person with who(m) D.A.F. Maria talked ( $3^{\text {rd }}$ S. Perf.).

(27) *A pessoa que a Maria falou com. (D. A. F.) person that (Compl.) D.A.F. Maria talked ( ${ }^{\text {rd }}$ S. Perf.) with.

Stranding the preposition is licensed in BP in rare cases of, for example, topicalization, as shown in (28) and illustrated in Figure 7:

(28) Isto, eu sou contra! This, I am against!

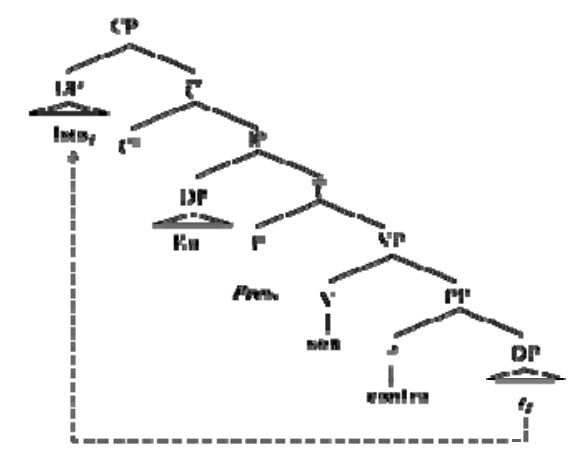

Figure 7. P-stranding in Topicalization as (28)

Significant to this discussion, is the fact that BP also allows for preposition ellipsis, or preposition deletion, in certain types of relative clauses (Salles, 2001) (Souza, 2007) - known as prepositional-phrase chopping relative clauses (relativas cortadoras). 
Sentence (29) exemplifies one such clause in BP, first with its base form (BF), then with its surface form (SF), and finally, with the surface form not containing the PP:

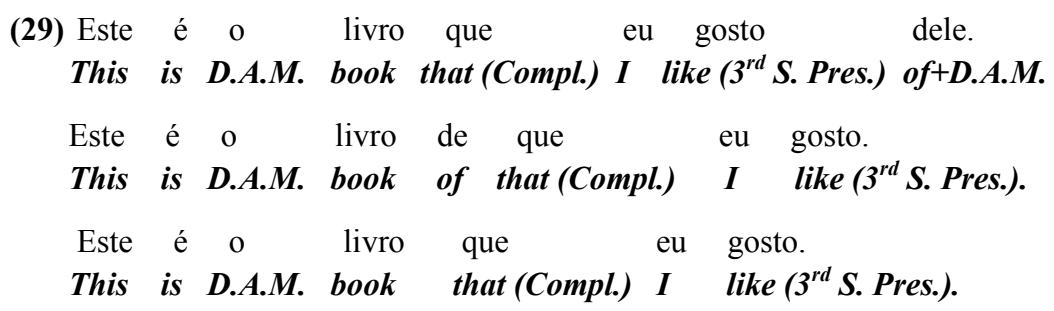

The latter example, where $\mathrm{P}$ (or the whole PP?) is no longer present, is the preferred solution of most BP colloquial varieties. Indeed, the first solution, where the PP is moved out of VP in the subordinate clause, is no longer highly productive in Brazilian Portuguese.

There is much debate in the literature as to what is the true nature of the syntactic structure in clauses like (29) above: is 'que' a complementizer or a relative pronoun here? If 'que' is a complementizer, has the pronoun been moved and deleted, or not moved and deleted? As for the PP, has it been deleted in situ? Has it moved from original position an then been deleted? Or has only P been deleted, and its pronominal complement remains in the form of 'que'? Souza (2007), provides a detailed account of such questions, as well as an indepth review of the relevant works found in the literature.

The fact that the preposition is not present in some relative clauses in BP might be relevant to this study in the sense that an extension of this P-ellipsis appears to also happen in some instances of QU- interrogative clauses produced by HS of Brazilian Portuguese.

The true nature of the syntactic structure of the PP-chopping relative clauses is not immediately relevant to the discussion at this point: the main concern is to determine whether there is a preference, by these participants, to generate QU- interrogatives with no preposition at all, rather than to use pied-piping or P-stranding. If it is found to be the case, though, that participants consistently elect P-ellipsis, then I will come back to the above discussion, as it will become relevant to future research projects in the topic, in which possible reasons for choosing the ellipsis structure would be investigated in further detail. 


\subsection{Movement Processes in PPs: Same Question, Different Approaches}

From the perspective of generativist syntax, most of the work done on P-stranding thus far has focused on determining which parameter(s), restrictions, or conditions license $\boldsymbol{P}$ stranding in languages (Law, 2006; Kayne, 1984; Stowell, 1982; Hornstein, Norbert, and Weinberg, 1981; Riemsdijk, 1978).

As a satisfactory answer to such question has proven quite elusive, some attempts have been made to answer to the opposing question, or, what parameters(s), restrictions, or conditions make mandatory the pied-piping of prepositions in languages (Salles, 2001, 1995).

Interestingly enough, Salles (Salles, 2001) claims are very similar to those made by Law (Law, 2006) just approached from opposite perspectives - i.e., what makes pied-piping a mandatory in some languages (Salles, 2001) vs. what licenses P-stranding in some languages (Law, 2006). Both these works are going to be discussed in the following paragraphs.

More recently, Sugisaki has conducted a series of works (Sugisaki, 2008; Sugisaki \& Snyder, 2005/2006; Rodriguez-Mondeñedo, Snyder \& Sugisaki, 2005; Sugisaki \& Snyder, 2003; Sugisaki \& Snyder, 2002) which demonstrate the relevance of studying child language acquisition with the objective of testing and finding evidence that corroborate/refute different hypothesis in theoretical linguistics, among which the licensing of P-stranding in languages.

\subsubsection{A Chronological Account of the Study of Preposition Stranding}

Many works have been produced - within both the early Generative Grammar and the Minimalist traditions - in an attempt to account for prepositions, prepositional phrases, and their respective behaviors, but Riesmdijk (1978) offered a comprehensive account of earlier works, and proposed a complete theoretic framework for P-stranding. Riemsdijk quotes Jackendoff (1973): “People seem never to have taken prepositions seriously". Indeed, Jackendoff (qtd in Riemsdijk, 1978) was perhaps the first one to offer a 
more diversified account of prepositional phrases in regards to their structure. Riemsdijk 's own justification to such neglect of the category was that: “...until very recently - the fact that PPs have never played a crucial role in the arguments for and against the changing conceptions about the theory of syntax within transformational grammar. ...” (Riemsdijk, 1978: 9).

In the ensuing chapters, Riemsdijk reviews previous work done on prepositions, prepositional phrases, and PP movement, starting with what he describes as Chomsky's “Aspects Position”, where Chomsky discusses PPs as being a result of verb subcategorization, therefore having three possible degrees of cohesion with the main verb (Riesmdijk,1978: 10-12), as follows:

1) $\mathrm{PP}=$ prepositional object, selected by the verb like a direct object.

2) $\mathrm{PP}=$ place adverbial, which occurs independently of the verb.

3) $\mathrm{PP}=$ adverbial PP, which nevertheless displays some kind of cohesion with the main verb.

Rules 1) and 2) above can be exemplified by ambiguous sentences like (30) below (Riemsdijk's (1), (2) and (2.a)), where two interpretations are possible:

(30) He decided on the boat.

He chose the boat.

He decided while on the boat.

The third rule, number 3) above is illustrated by sentences like (Riemsdijk's (3):11):

(31)... dashed int the room ( $\mathrm{V}-$ direction)

Riemsdijk notices though, that in the "Aspects Position", functional and structural properties of PPs are confused, and that phrase structure rules should reflect structural properties, not functional properties, and therefore this is an inadequate view of the matter.

Riemsdijk follows with a discussion of Ross' position on prepositional phrases, videlicet that $\mathrm{PP}=\mathrm{NP}$ (noun phrases). Ross is of the opinion that prepositions detain a unique role in syntax, but he also observes that, albeit the fact that prepositions can be stranded quite 
freely in English, they must, in some cases, be pied-piped along with their complement. According to Ross, a rule like (32) below would simplify the structural description of several transformations such as topicalization and WH- movement.

(32) $\mathrm{NP} \rightarrow \mathrm{P} \mathrm{NP}$

In regards to Fillmore's perspective that $\mathrm{P}=$ Case, derived from Fillmore's obsevations that many functions which are expressed by prepositions in English are rather expressed by case-marking in other languages, Riemsdijk recognizes that prepositions and case may be syntactically related, but concludes that the two cannot be two facets of the same prism, on the basis of the following arguments: first, Fillmore considers the relationship between prepositions and Case to be a privileged one, but disregards the relationship between verbs and Case, despite the fact that verbs and prepositions are often functionally related. Second, Riemsdijk notes that it is incorrect to assume an exclusively diachronic relationship between prepositions and case. Third, there are syntactic differences between preposition and case-markers, namely that while a preposition can select another PP as its complement, say a Dative NP cannot be subjected to case-marking again, and be marked, say, as Genitive. Riemsdijk also notices that Case is a property of Ns (Nouns and Noun Phrases) and of As (Adjectives and Adjectival Phrases), whereas P is an independent category. Lastly, Riemsdijk remarks that Fillmore did not take into consideration the fact that prepositions cannot be distributed inside the NP onto the Determiner, the Adjective, the Noun, just like Case is in many languages.

Finally, Riemsdijk's own proposal is to integrate Jackendoff's EST (Extended Standard Theory of Syntax) account of the structure of prepositional phrases (itself derived from Klima's and Emonds' idea that prepositions and prepositional phrases were a syntactically independent category) in the theory of Syntax "by investigating the role that $\mathrm{P}$ and PP play with respect to the constraints on transformations that are part of the theory"(Riemsdijk, 1978:22). 
Riemsdijk (1978) investigated prepositions, prepositional phrases and P-stranding in Dutch and in English proposed two different motivations for P-stranding, having noticed that P-stranding behaves differently in relative clauses and in interrogative clauses (Riemsdijk, 1978:ch.6). Hence he proposed that, when P-stranding is the result of DP movement (relative clauses), it followed from "the independently needed mechanism of lexical reanalysis" (Riemsdijk, 1978:255). Preposition stranding resulting from WH- movement, on the other hand, needed an "escape hatch" (Riemsdijk, 1978:255), that he posed in the form of the rule $\mathbf{P} ", \rightarrow$ COMP P', (where $\mathrm{P}$ ", is the complementizer phrase of $\mathrm{P}$ ", hence the WH-word raises to pec CP by means of first "escaping" from PP to a COMP PP position). Riemsdijk suggests that, if P-stranding is the result of an extraction operation, then it has to abide to the generic constraint on extraction, or the Head Constraint (HC), which states that the head of a phrase cannot move into a maximal projection position.

Hornstein and Weinberg (1981), propose that the presence (or not) of P-stranding in a given language is "the result of the operation of three different mechanisms: (a) A universal Case-marking convention; (b) A universal filter blocking oblique traces; (c) A languagespecific rule of syntactic reanalysis" (Hornstein \& Weinberg, 1981:55). They note that taking into consideration the Subjacency Theory (which postulated - at the time - that a one instance of movement could cross at most one single binding node), and claiming that both PP and S (sentence) are binding nodes, P-stranding would become an impossibility in English.

Furthermore, Hornstein and Weinberg observe that the notion of "escape hatches" brought forward by Riemsdijk to explain P-stranding - where the PP has (an empty) complementizer spot through which the prepositional complement can escape - does not hold in sentences like (33) below (their (2), pp 56), in which the PP would not be generated with a COMP, and thus movement would still be blocked under the Subjacency condition.

(33) What inning did the Yankees lose the ball game in? 
Hornstein and Weinberg hence advance a solution from the perspective of Case Theory: languages may apply to VP a syntactic rule of reanalysis. The rationale is as follows: (A) there exists a universal filter which states that traces of NPs marked as oblique by the Case-marking conventions are deemed ungrammatical. (B) There is a syntactic rule of Reanalysis that says that within a VP, V (Verb) and any number of contiguous elements to its right can form a complex V. Reanalysis is optional, and Case-marking follows it. (C) There are Case-marking rules that occur after all transformational rules have been applied and before filters apply, assigning Case to NPs (Hornstein \& Weinberg, 1981: 60). In other words:

a. Syntactic Rule of Reanalysis: $\mathrm{V} \rightarrow \mathrm{V}^{*}$ (complex verb - plus V c-commands $\mathrm{V}^{*}$ )

b. Oblique Case Filter applies: ${ }^{[}[\mathrm{NP}$ e]

c. Case-marking rule $*[\mathrm{NP}$ e $]$
+ toblique

The framework described above would account for both the unacceptability of (34) and the grammaticality of (35) (Hornstein \& Weinberg's (26) and (27), respectively):

(34) * What time did John arrive at $t_{1}$ ?

(35) Who did John talk to Harry about?

Sentence (34) is ungrammatical because the trace $t_{1}$ is marked as oblique by the Casemarking rules: as per the universal filter which states that traces marked as oblique are unacceptable, the sentence is starred. Hornstein and Weinberg emphasize that in (34), the rule of Reanalysis cannot be applied to VP, since the PP at what time is dominated by S and not by V. Such structure causes the trace $t_{1}$ to be marked as oblique, and the universal filter to be applied. In sentence (35), on the other hand, the rule of Reanalysis can be applied to the PP about who, which is $\mathrm{C}$-commanded by $\mathrm{VP}$, creating the complex verb $\mathrm{V}^{*}$ talk to Harry about, and allowing WH- movement of who. Case-marking then applies and who, along with its trace $t_{1}$, are marked with objective case, and as a result, the universal filter cannot apply. The whole derivation is shown in (36):

(36) [s, [c ] [s John [vp [v talk] [pp to Harry] [pp about who]]]] [s, [c ] [s John [vp [v talk to Harry about] who]]] 


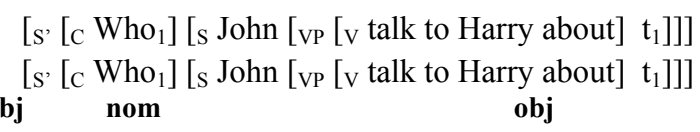

Kayne (1984, qtd. in (Law,2006), (Salles, 2001)) adopted the Reanalysis Rule proposed by Hornstein and Weinberg for English, but also proposed a constraint on the reanalysis, in the form of: elements that are submitted to reanalysis must be governed in the same way. Kayne's proposal accounted for both the fact that P-stranding exists in English, and for the fact that it is absent in Romance languages: his argument was that both Vs and Ps assign structural case in English (hence P-stranding is allowed), whereas in French, for example, Ps do not govern (non-binding) and assign structural case like Vs (hence, Pstranding is not possible). According to Law though, Kayne's proposal would not account for some cases of P-stranding in Dutch (Law, 2006: 644, his (51)), and therefore its crosslinguistic empirical coverage would be confined to English and Romance.

Law (2006) and Salles (2001) emphasize that Romance languages do not allow for Pstranding, and evince the fact that these languages display D-to P incorporation - otherwise stated, these languages allow for cliticization of determiners to prepositions, i.e., Portuguese determiner "o" (D.A.M) cliticizes to prepostion "de" (of), forming the "do", the same being true for French (determiner "le" cliticizes to preposition "de" = "du"), and for Italian (determiner "il" cliticizes to preposition "de" = "del"). The same rule applies to many other prepositions and determiners in all three languages. Law calls this type o cliticization process suppletion and proposes the rule of Syntactic Constraint on Suppletion: "Elements that undergo suppletive rules must form a syntactic unit $\mathrm{X}^{0}$, as shown in the structure below - his (60), pg 646:

$$
\text { (37) }\left[\mathrm{PP}\left[\mathrm{P}^{0}+\mathrm{D}_{\mathrm{i}}^{0}\left[\mathrm{DP}\left[\mathrm{t}_{\mathrm{i}}\left[\mathrm{NP}\left[\mathrm{N}^{0}\right]\right]\right]\right]\right]\right]
$$

In structure I above, D no longer forms syntactic constituent with the following NP and thus NP cannot be moved out of PP, since Scwartz (1972, qtd. in Law (2006)) posits a constraint against moving non-constituents (Law, 2006:646). 
One question remains in regards to the Syntactic unit solution proposed by Law - also in Salles (2001) - is that of how to offer an explanation to Spanish, where, in the varieties I know of (Argentinian, Uruguayan, Mexican, Colombian, Venezuelan, European), D-into-P incorporation is not allowed (except for the case of the preposition "de" and the definite masculine article "el" = del; no other determiners I know of incorporate into prepositions). The above could, of course, be a matter of diachronic variation in Spanish, which would account both for the remainder "el" into "de" incorporation, and for the absence of Pstranding in this language according to Law's explanation, but it remains unclear.

More recently, Sugisaki (2008) and Sugisaki \& Snyder (2002) used studies in child language acquisition and corpora analysis to present compelling argument in favor of Stowell's (Stowell, 1982) proposition that only natural-language grammars that have verb + particle constructions allow for P-stranding. Stowel's account provides yet another puzzling facet to the prism of P-stranding in BP: it is interesting, to say the least, that heritage speakers of BP correctly analyzed their L2, English, as allowing for P-stranding on the account of having particle verb constructions, but then analyzed BP, where particle verbs are nonexistent, as having the same setting for this parameter. Unless there is some construction, other than particle verbs in BP, which might lead these speakers to draw a similar conclusion about the possibility of leaving the preposition stranded.

\subsection{A Word on Movement and Theoretical Syntax}

A concise account of earlier versions of the Extended Standard Theory of Transformational-Generative Grammar, led by Chomsky's (but not exclusively) seminal works on the topic, is given by Riemsdijk, and is as follows:

A grammar, in this view, consists of a core and a periphery. The core part of grammar consists of a limited number of transformational rules that have the form "move $\alpha$ ", where $\alpha$ is some category. The constraints and other components of the grammar ensure that this optimally constrained grammar does not yield any unwanted results. Transformations may be formulated with richer structural 
descriptions, subject to certain limitations, but such transformations are considered peripheral and are marked in terms of optimality measure that is part of linguistic theory.

The organization of grammar as specified by this work takes the following structure:

1. Base

2. Transformations
3.a. Deletion
3.b. Rules of construal
4.a. Filters
4.b. Quantifier interpretation, etc
5.a. Phonology
6.a. Stylistic Rules

The base component consists of a set of unordered context-free phrase structure rules. This rule system is specified by some version of the X-bar theory. The output of the base component, deep structure, serves as input for the transformational component which maps deep structure into surface structures. The core transformations are assumed to be optional and unordered with respect to each other... Transformational operations are restricted to adjunctions and structurepreserving movements. Positions vacated by a (string of) terminal element(s) as a result of a movement transformation are taken to be coindexed with the category dominating these terminal elements in derived structure according to the principles of the trace theory of movement rules. The surface structures thus obtained serve as input to two independent mappings: via 3.a. through 6.a. into phonetically interpreted strings and via the various interpretative subcomponents 3.b., 4.b., into logical forms.

Figure 8 below provides a visual representation of grammar as described by the above theory: 


\section{Grammar structure}

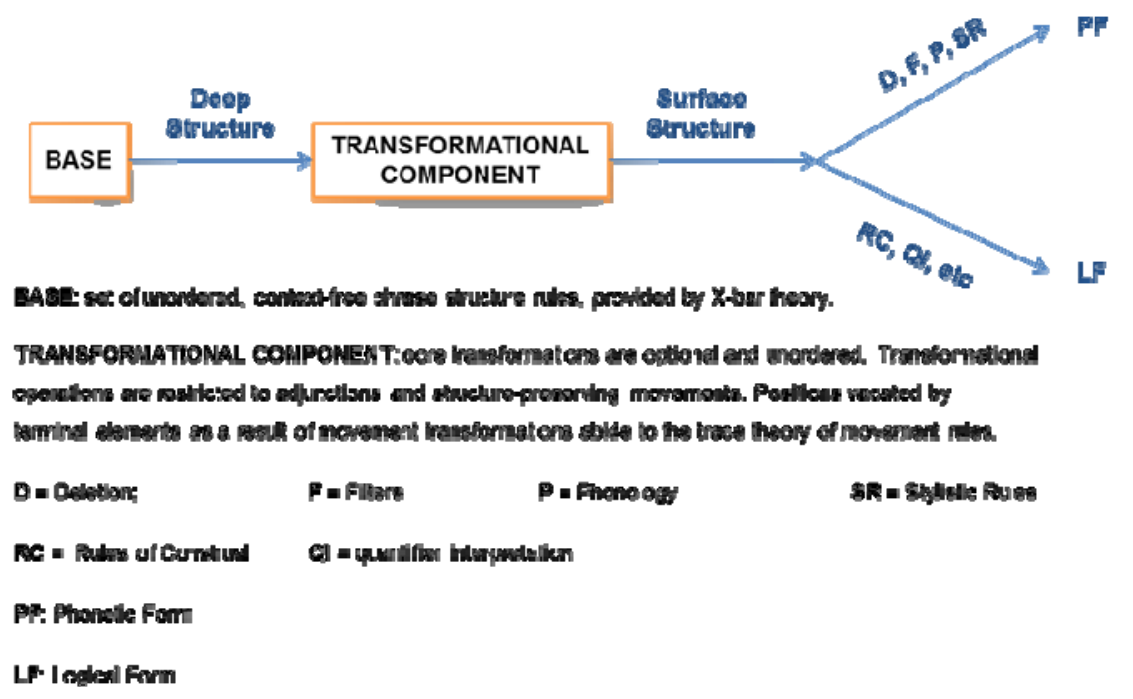

Figure 8. The EST of Transformational-Generative Grammar

In subsequent works this theory of transformational-generative grammar develops into the Principles and Parameters framework of generative grammar, in which a grammar is said to consist of a finite set of principles which are universal, common to all languages, and of a set (also finite) of binary parameters, which are set to distinct values, thus originating languages which are syntactically distinct among each other. Within this framework, the process of first language acquisition is described as consisting of numerous parameter setting operations. It follows that the native speaker's stable grammar includes parameters which have hence been set to the target value of that speaker's native language. Figure 9 below shows the classic T-model of grammar in the P\&P framework, according to Chomsky (1981): 


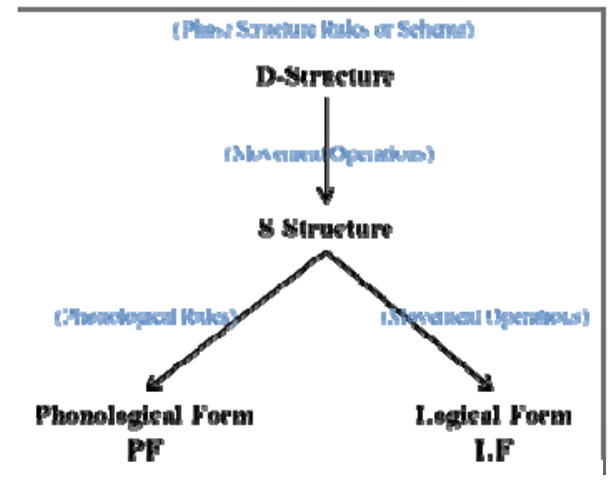

Figure 9. Classic T-Model of P\&P (Chosmky, 1981)

The Minimalist Theory of syntax can be considered to be, from a certain perspective, a refinement of the decades of Transformational Generative Grammar. The core assumption of the Minimalist Program is that both the abstract structure representation of a sentence, and the transformations it can subsequently undergo have to abide to an economy principle. Such principle requires that there be "no extra steps in derivations and no extra symbols in representations, and no representations beyond those that are necessary for the system to function at all in connecting sound (or, in the case of signed languages, gesture) and meaning”, quoted from Chomsky in (Bošković \& Lasnik, 2007).

Movement became a major issue in the Minimalist program of syntax: as a direct consequence of the economy principle, movement should only happen as "a last resort" (Chomsky in Bošković \& Lasnik, 2007:3), driven by some feature which will force such movement to happen in order to be "checked". Feature checking is necessary to delete all uninterpretable (i.e., syntactic) features from the derivation before it reaches PF and LF, in order for the derivation to converge. Some of the features which are known for having the ability of "forcing" movement are Case, Agreement, and Q-operator (WH-/QU- movement). In this sense, movement in WH-/QU- interrogatives in both American English and Brazilian Portuguese is driven by the Q-feature - which is deemed strong in both languages, on the account that such movement is overt. The Q-feature forces the WH-/QU- word to raise to the left-most periphery of the sentence in order to be checked. While in American English, in 
interrogatives containing PPs, such feature checking can be done by raising only the WHword, leaving P stranded, in Brazilian Portuguese the Q feature is checked by raising the entire PP to CP position - prepositional head plus its complement, the QU- word.

\subsection{A Word on Markedness}

One of the assumptions commonly accepted in modern linguistics is that there exists a Universal Grammar, and that hence there are universal aspects of language, known as language universals, which would be predetermined by the Universal Grammar. One attested universal aspect of languages is markedness. The term itself was introduced by Trubetzkoy in the 1930s, applying to phonology. There is vast literature on the subject - see Hume (2011) for a comprehensive discussion - but, in a somewhat generic definition, markedness is the term used to explain asymmetries in languages: in this sense, unmarked refers to language elements or classes which are "more frequent, natural, simple, and predictable" (Hume, 2011:80) than their counterparts observed in the marked comparison set. Unmarked elements are thought to be "the default member of a class" (Hume, 2011:80).

In a Theory of Markedness - again, despite the fact that there are numerous attempts to develop such a theory in the literature, from various different perspectives, too - the core assumptions are (Faingold, 2003):

I. The more marked element tends to change to the less marked element

II. The presence of a more marked element implicates the presence of the lessmarked counterpart

Such Theory of Markedness is used as a tool in an attempt to describe and explain several linguistic phenomena, including, but not limited to, diachronic variation in language, child language acquisition, second language acquisition, and second language learning. Markedness theory, in regards to child language acquisition, states that children will favor less-marked forms, omitting or replacing the more-marked form with its less-marked counterpart (Faingold, 2003:5). 
In what concerns movement processes targeting prepositional phrases, as discussed in chapter 1.1, P-stranding and PiP can be viewed as the "two possible settings" for the parameter "move PP": PiP is the unmarked setting, highly common cross-linguistically, while P-stranding is its marked counterpart, found only in a handful of languages, among which American English.

\subsection{The Interface Hypothesis}

The Interface Hypothesis was brought forward by Sorace and colleagues (Tsimpli, Sorace, Heycock and Filiaci, 2004; Sorace, 2005; Sorace and Serratrice, 2009; Sorace, 2011), offering a means to categorize which domains in bilingual syntax are vulnerable. In its initial form, the Interface Hypothesis proposed that structures which are at the interface of syntax with other cognitive domains are more vulnerable to incomplete acquisition, while narrowsyntactic structures would be candidates to complete acquisition.

Tsimpli, Sorace, Heycock and Filiaci (2004) noted that in regards to Chomsky's generative framework, "language acquisition is a process of parameter setting" (Chomsky, 1986, 1995, qtd in Tsimpli, Sorace, Heycock and Filiaci, 2004), and that hence "the steadystate of the grammar in the native speaker's mind includes parameters set to the target value" (Tsimpli, Sorace, Heycock and Filiaci, 2004: 258).

In this same study, the authors remark that if syntactic attrition (within the framework of generative grammar), were to be defined as a "set of changes in L1 syntactic competence", this would formally translate into "a loss or resetting of L1 parametric values under L2 influence" (Tsimpli, Sorace, Heycock and Filiaci, 2004: 258). However, they observe that multilingual individuals do display distinct autonomous grammar systems (whether native or non-native), so they propose that the difference between two languages goes beyond parameter setting exclusively, explaining that the grammatical options provided by such settings may be used to achieve different semantic/pragmatic objectives, and that it is this use 
of grammatical options which can be affected by attrition (Tsimpli, Sorace, Heycock and Filiaci, 2004: 258).

Furthermore, Tsimpli, Sorace, Heycock and Filiaci explain that, in the Minimalist theory of syntax, the distinction between the exclusive parameter setting and the use of these settings to accomplish different semantic/pragmatic goals corresponds to the distinction between uninterpretable (such as Case and Agreement) - which drive the syntactic derivation and "may be parameterized to yield the different syntactic options available in different languages" (pp. 258) - and interpretable features - which "can be read by the conceptual/intentional systems of cognition" (pp. 258). Only parameters associated to the value of uninterpretable features can be responsible for crosslinguistic difference, but interpretable features can make use of these parametric value settings.

In light of the information discussed above, Tsimpli, Sorace, Heycock and Filiaci brought forward the following hypothesis: syntactic attrition will affect morphosyntactic features that are interpretable at LF, but not those features which are uninterpretable. The hypothesis was devised on the basis of three assumptions: (1) that the cognitive state of mature language (attained once the Critical Period of language acquisition is over) does not permit optional syntactic processes; (2) the set of uninterpretable features is modular, and cannot be the subject of top-down effects; (3) the LF-interface and the representation it yields, on the other hand, are not modular, thus being vulnerable to attrition. In the authors' own words:

Specifically, we expect L1 attrition to involve interpretable features that are linked to a parametric choice that differs between the L1 and the L2. In this way, an interpretable feature that is specified in L1 in a particular syntactic structure will become unspecified due to the absence of a similar interpretable feature in L2 in the same syntactic context. This underspecification gives rise to optionality (see Sorace, 1993, 2000). Attrited grammars are then expected to show more "ambiguity" in the interpretation of lexical items (null or overt) since conflicting options associated with L1 and L2 will be accessible at the interface. However, uninterpretable feature values that distinguish between the parametric choices of L1 and L2 will not be affected through attrition and therefore no optional "syntax" is expected to be found. 
A large corpus of research has been produced since the original proposal, focusing on testing various structures, in several languages, at different interfaces. Still, a clear definition of narrow-syntax, a core concept to the hypothesis, remains elusive. The very existence of structures that require only syntactic computations has been questioned in (Montrul, 2011), and in a recent review of the work developed with the IH (Sorace, 2011:1), Sorace herself raises the same question.

In the same review, Sorace analyzes what she qualifies as overextensions of the hypothesis, questioning which population the IH should be applied to. Montrul and Polinsky (Montrul \& Polinsky, 2011), make the point that the Interface Hypothesis certainly applies to heritage speakers, which is the assumption adopted in the present study.

In light of the Interface Vulnerability Hypothesis laid out above, and keeping in mind the discussion in chapter 2.3, in which movement processes targeting PPs in WH-/QUinterrogatives happens driven by the necessity of checking a Q- feature, it is expected that these movement processes, being the different parametric values of an uninterpretable feature (Q-) would not be subject to syntactic attrition.

\section{RESEARCH QUESTIONS AND HYPOTHESES}

Having lived among heritage speakers of Brazilian Portuguese for so long, and having taught Portuguese to different age groups of HS - including college-aged HS -the last several years have made it clear to me that influence and transfer are not unidirectional phenomena, from the more dominant to the less dominant language. Several observations can be mentioned:

- From the perspective of a Markedness theory, if heritage speakers of Brazilian Portuguese indeed resort to P-stranding when speaking their heritage language, such use would counter the notion that children acquiring a language favor the less-marked value of a feature. In fact this would be all 
the more unexpected, considering that these speakers do have access to two linguistic systems, one which uses the unmarked construction, and a second one which resorts to a highly-marked solution.

- From the perspective of the Interface Hypothesis, movement processes targeting PPs, which are triggered by the checking of an uninterpretable feature, are predicted to not undergo attrition. In other words, HS of BP are predicted to resort to PiP in their Brazilian Portuguese, and continue to use Pstranding in their American English. Therefore, if evidence is found that HS of BP indeed use $\mathrm{P}$-stranding in their $\mathrm{BP}$, this would constitute a counterexample.

- From the perspective of the Minimalist theory of syntax, however, the use of P-stranding by HS of BP, in addition to their awareness of instances where movement of any kind is barred, could constitute evidence in favor of the workings of the Principle of Economy in Language Acquisition. In other words, these heritage speakers, exposed to two linguistic systems, become aware that movement is necessary in order to check a Q- feature, but notice that there are structures in which "less material (i.e., only the WH- word, not the entire PP) can be moved in order for checking to take place", and hence prefer the more Economical solution, P-stranding.

\subsection{An Epistemic Account Based on Qualitative Observations}

If I were to provide an analysis of heritage speakers and the use of prepositional phrases on the basis of qualitative observations made through the years, it would be as follows: in the case of South Florida, P-stranding in BP is not in the linguistic input heritage speakers receive. At least first-born heritage speakers - provided that their parents speak Portuguese to them - will acquire target-like movement of PPs in QU- interrogatives, but this structure will undergo (early) attrition once the schooling process is well underway (usually 
by age 6 ). The assertion is derived from observations made with my son, and from accounts coming from the two parents mentioned in chapter 1.1. Younger siblings, maybe because of diminished exposure to the heritage language (they usually talk to their siblings in their L2), will be less likely to acquire the target structure, and will use the L2 structure in both languages, without undergoing attrition in their L1. Additionally, also taking into account parents' narratives, the prediction is that those heritage speakers who were born in Brazil and who came to the United States at a later age will also be subject to attrition (in what concerns PP movement), at some point, a fact most likely linked to the length-of-residence (LOR) in the United States.

The effectiveness of corrective feedback from parents as a tool in the child's language acquisition process is controversial, and these speakers' heritage language is not subject to the common pressures exerted by external factors, such as schooling and social prestige of a linguistic structure (since they do not use Portuguese in contexts other than the home context). Therefore, unless these heritage speakers become exposed to an increased, richer linguistic input in their heritage language for a reasonable period of time (where the definition for reasonable is not defined), they will continue to use the non-target structure of P-stranding in $\mathrm{BP}$, which is the syntactically more economical solution, because it involves moving less structural material.

This account is precisely what the name implies: a reflection. The principal questions the study at hand seeks to explore - and which are postulated below - are much less ambitious in nature, although the present reflection will be reviewed in light of the final findings.

\subsection{Research Questions and Hypotheses}

RQ 1: Do HSs of BP use P-stranding in Portuguese?

HYPOTHESIS 1: The hypothesis is that HS of BP use P-stranding. 
RQ 2: If such is the case, is the use systematic?

HYPOTHESIS 2: The hypothesis is that HSs of BP use P-stranding systematically.

Three factors are taken into consideration to provide evidence for this hypothesis:

first, P-stranding in interrogatives containing verbs that select a PP as their complement in

Portuguese, but not in English. One such verb is to like (gostar), as shown in (38) and (39), and illustrated in Figure 10 and in Figure 11.

(38) Ana likes what.

What does Ana like?
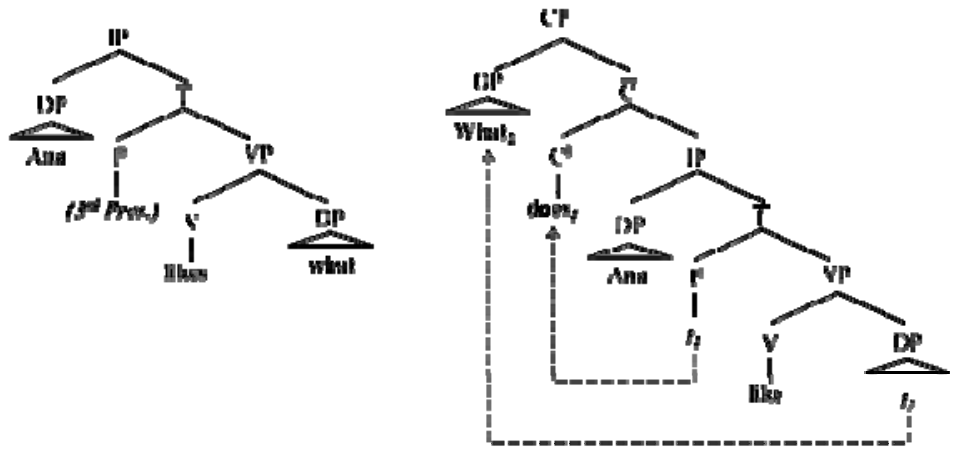

Figure 10. WH- movement: base and surface structures

(39) A Ana gosta de chocolate.

D. $A . F$. Ana like $\left(3^{\text {rd }} S\right.$.) of chocolate.

Ana likes chocolate.

De que (que) a Ana gosta?

Of what (Compl.) D. A. F. Ana like ( ${ }^{\text {rd }} S$ Pres.)?

What does Ana like?

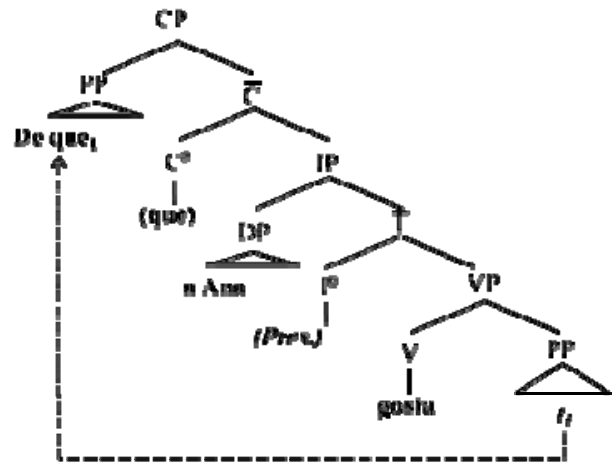

Figure 11. PiP in the sentence "A Ana gosta de (o) que." 
The prediction is that participants will use P-stranding, shown in (40), illustrated in

Figure 12:

(40) *Que (que) a Ana gosta de?

What (Compl.) D. A.F. Ana like $\left(3^{\text {rd }} S\right)$ of?

What does Ana like?

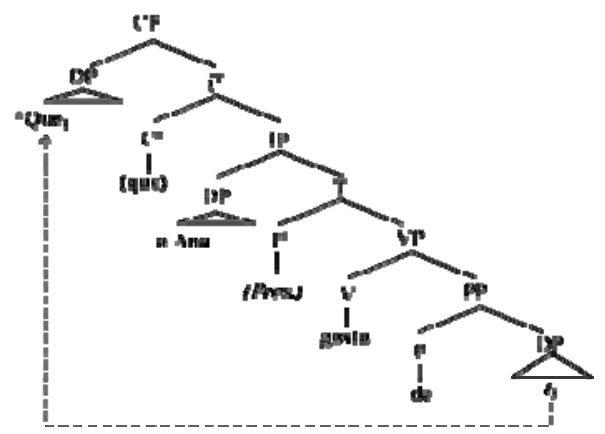

Figure 12. P-Stranding in "A Ana gosta de (o) que"

The second factor which can provide evidence for systematicity comes from

sentences where WH-/QU- movement in any form is barred, as in (41), illustrated in Figure

13 and Figure 14, and in (42), illustrated in Figure 15 and in Figure 16:

(41) John drank the cup of tea.

*What did John drink the cup of?

*Of what did John drink the cup?

?John drank the cup of what? (echo questions?)

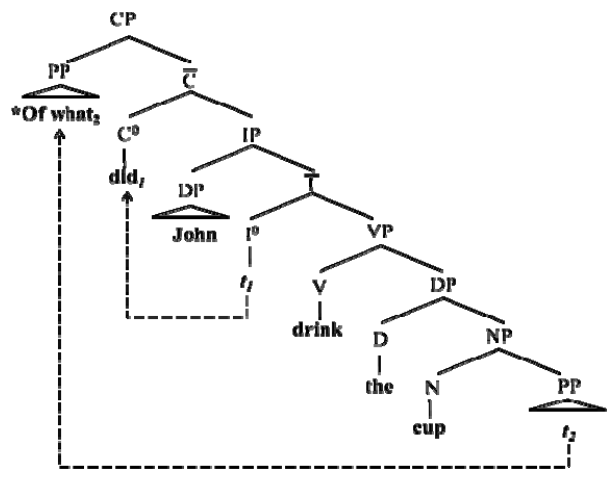

Figure 13. PiP in sentence (41) 


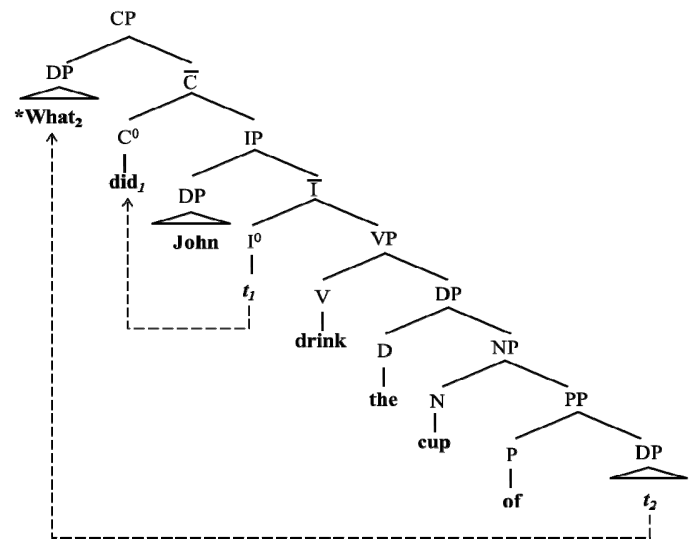

Figure 14. P-stranding in sentence (41)

(42) $\mathrm{O}$ João comeu $\quad$ o prato de feijão.

D.A.M. João eat ( ${ }^{\text {rd }} S$ Perf.) D.A.M. plate of beans.

*De que (que) o João comeu o prato?

Of what did John eat the plate?

*Que (que) o João comeu o prato de?

What did John eat the plate of?

?O João comeu o prato de quê?

?John ate the plate of what?

O que (que) tinha no prato que o João comeu?

What was in the plate (that John ate)?

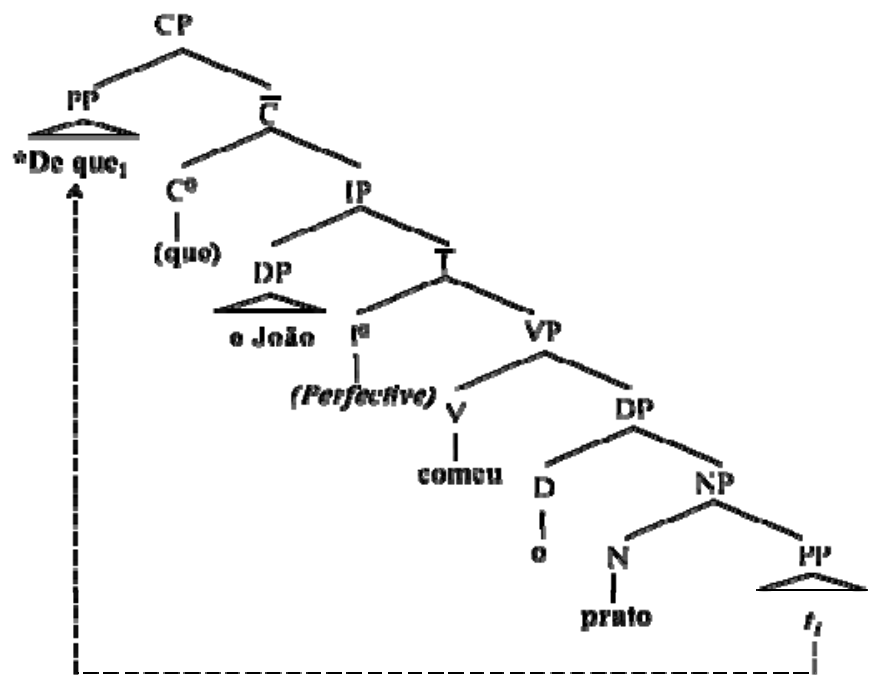

Figure 15. PiP in sentence (42) 


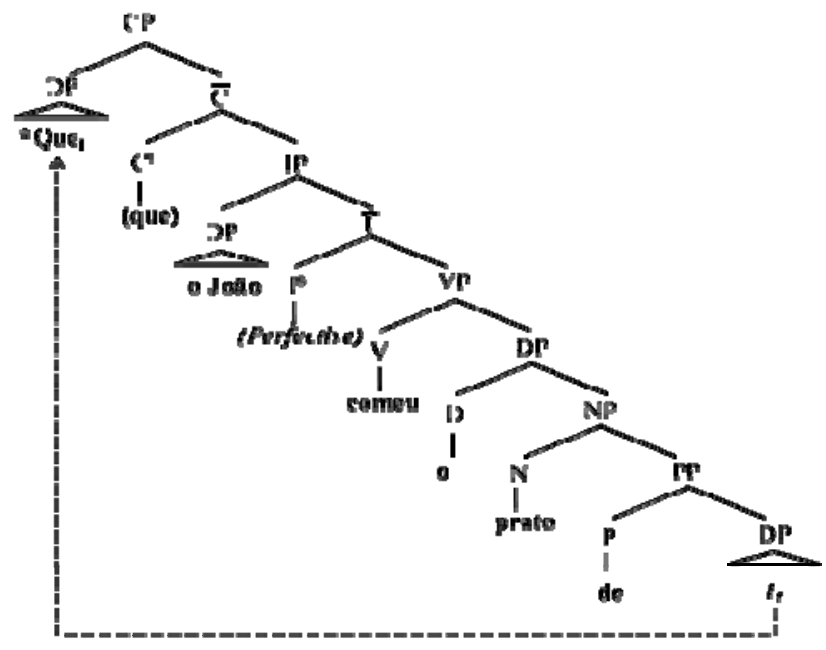

Figure 16. P-stranding in (42)

RQ 3: What is the structure of choice when P-stranding is not used?

HYPOTHESIS 3: The hypothesis is that the next preferred structure is P-ellipsis,

followed by the use of in situ QU- interrogatives ${ }^{2}$, and that PiP is the last resort, if not

completely absent from HS' speech.

It is important to mention that some varieties of $\mathrm{BP}$ - including northern varieties such as the ones in Alagoas and in Bahia (de Souza, 2007; Grolla, 2005) - use in situ QUwords as the preferred structure for any interrogative, in lieu of the regular configuration of BP, where interrogatives usually pied-pipe the PP along with its $\boldsymbol{Q U}$-complement, and where in situ $Q \boldsymbol{Q}$ - interrogatives are used either for the effect of echo questions, or for pragmatic reasons, in cases where the speaker has reason to believe that the hearer is able to answer speaker's question (Ferreira-Sell, 2002; Grolla, 2005). Although a few of the participants come from families that have their origins in northern Brazil, in situ QU- interrogatives are not expected to be produced by participants in a significant number, except with respect to the hypothesis for research question 3 below. The main reason for thinking that participants will not resort to in situ QU- interrogatives, lies in the fact that studies have shown that although

\footnotetext{
${ }^{2}$ Some varieties of BP, including northern varieties such as those in Alagoas and Bahia (de Souza, 2007), (Grolla, 2005), use in situ QU- words in lieu of pied-piping as a preferred structure for interrogatives. This is in contrast to the typical BP pattern of in situ $\boldsymbol{Q U}$ - interrogatives for the effect of echo questions, or pragmatic reasons (Ferreira-Sell, 2002) (Grolla, 2005). WH-in situ questions are claimed to be non-productive in child's speech in BP (Grolla, 2005).
} 
this solution is fairly frequent in BP adult speech, it is almost inexistent in child's speech (Grolla, 2005).

RQ 4: Do the results of the elicitation task converge with the results of the grammaticality judgment task?

HYPOTHESIS 4: The hypothesis is that there may be disparity between the results of the two experiments. The disparity may correlate with: age, frequency of language use (BP), early acquisition of BP in Brazil, and corrective feedback provided to HS by caregivers. Confirmation of research hypotheses, particularly Hypotheses 1 and 2, provides evidence that questions the Interface Vulnerability Hypothesis (Sorace, 2005; Müller and Hulk, 2000), (Tsimpli et al., 2004), (Iverson, 2010), which proposes that purely syntactic structures are not expected to be subject to attrition, nor to incomplete or protracted acquisition.

Furthermore, confirmation of research Hypotheses 1 and 2 would pair with one of the findings by Depiante and Thompson (2012) in an experiment done with HS of Spanish, namely that change in HS syntax is NOT restricted to areas of the grammar where syntax interfaces with interpretable domains.

\section{METHOD}

\subsection{Participants}

Thirty heritage speakers of BP, between the ages of 4 to 16, children of Brazilian immigrants, who live in the tri-county area of South Florida, took part in this study. In light of the impossibility of carrying out a longitudinal study to pair with the present investigation, participants of different ages have a greater potential of providing data that could be evidence for protracted acquisition, early attrition, optionality, and developmental stages.

\subsubsection{Language Dominance}

American English is the majority language of the broader social context in South Florida, and the presence of Spanish is much less noticeable in North Broward and in Palm 
Beach counties than it is in Miami-Dade County. Brazilian Portuguese is the L1 of all participants, although their L2, American English, is the dominant language at the time of the experiment. Although a number of methods to assess language dominance are described in the literature, such evaluation lies beyond the scope of the present study: the term dominant language, whether referring to participants' $\mathrm{L} 1$ or L2, is herein used to indicate the language in which the participant can comfortably sustain a conversation. These data were both selfreported and taken from the researcher's qualitative observations, made during the experiments.

\subsubsection{Recruitment and Participants Information}

Participants were recruited among families who attend Manhã Brasileira, a Saturday school located in Boca Raton, where students can learn Portuguese and Brazilian culture. Participants who do not attend Manhã Brasileira were referred by families in the program. All participants are first generation heritage speakers of Brazilian Portuguese.

Roughly twenty-five percent (25\%), of participants $(N=7)$, were born in Brazil and came to live in the United States, along with their families, after age 6 (age of arrival-AOA $\geq 6$ years of age). These participants were included in the study so to provide a sample of heritage speakers who were exposed to a much richer linguistic input in their L1, and who were exposed to their L2 at a much later age. Nonetheless, English is still these speakers' dominant language. These 8 speakers all had some schooling experience in Brazil. Table 1 below gives a detailed description of heritage speaker participants, while Table 2 shows a summary: 


\begin{tabular}{|c|c|c|c|c|c|c|c|}
\hline Participant & Age (y) & Gender & Place of Birth & School & AOA & Father & Mother \\
\hline $\mathrm{P} 1$ & 9 & $\mathrm{~F}$ & Brazil & 3 & 6 & BRA & BRA \\
\hline $\mathrm{P} 2$ & 7 & M & U.S. & 1 & 0 & BRA & BRA \\
\hline $\mathrm{P} 3$ & 13 & M & U.S. & 7 & 0 & BRA & BRA \\
\hline $\mathrm{P} 4$ & 9 & $\mathrm{~F}$ & U.S. & 3 & 0 & BRA & BRA \\
\hline P5 & 7 & $\mathrm{~F}$ & U.S. & 2 & 0 & BRA & BRA \\
\hline P6 & 9 & $\mathrm{M}$ & U.S. & 4 & 0 & BRA & BRA \\
\hline $\mathrm{P} 7$ & 5 & $\mathrm{~F}$ & U.S. & $\mathrm{K}$ & 0 & BRA & BRA \\
\hline P8 & 11 & $\mathrm{M}$ & Brazil & 6 & 0.3 & BRA & BRA \\
\hline P9 & 4 & $\mathrm{~F}$ & U.S. & 0 & 0 & BRA & BRA \\
\hline $\mathrm{P} 10$ & 7 & $\mathrm{~F}$ & U.S. & 1 & 0 & BRA & BRA \\
\hline $\mathrm{P} 11$ & 12 & $\mathrm{~F}$ & U.S. & 6 & 0 & NOR & BRA \\
\hline $\mathrm{P} 12$ & 12 & $\mathrm{~F}$ & Brazil & 6 & 9 & BRA & BRA \\
\hline P13 & 9 & $\mathrm{M}$ & U.S. & 3 & 0 & BRA & BRA \\
\hline P14 & 6 & $\mathrm{M}$ & U.S. & 1 & 0 & BRA & BRA \\
\hline P15 & 7 & $\mathrm{~F}$ & U.S. & 1 & 0 & BRA & BRA \\
\hline P16 & 11 & $\mathrm{~F}$ & U.S. & 6 & $0 *$ & FR & BRA \\
\hline P17 & 9 & $\mathrm{M}$ & U.S. & 4 & $0 *$ il & FR & BRA \\
\hline P18 & 15 & $\mathrm{M}$ & U.S. & 10 & 0 & BRA & $?$ \\
\hline P19 & 14 & $\mathrm{~F}$ & U.S. & 9 & 0 & BRA & BRA \\
\hline $\mathrm{P} 20$ & 10 & $\mathrm{~F}$ & U.S. & 5 & 0 & BRA & BRA \\
\hline $\mathrm{P} 21$ & 16 & $\mathrm{~F}$ & Brazil & 11 & 12 & BRA & BRA \\
\hline $\mathrm{P} 22$ & 12 & $\mathrm{M}$ & Brazil & 7 & 10 & BRA & BRA \\
\hline P23 & 10 & $\mathrm{M}$ & Brazil & 5 & 8 & BRA & BRA \\
\hline P24 & 14 & $\mathrm{M}$ & Brazil & 9 & 13 & BRA & BRA \\
\hline $\mathrm{P} 25$ & 9 & $\mathrm{~F}$ & U.S. & 3 & 0 & BRA & BRA \\
\hline P26 & 10 & $\mathrm{~F}$ & U.S. & 4 & 0 & PER & BRA \\
\hline P27 & 14 & $\mathrm{~F}$ & Brazil & 9 & 8 & BRA & BRA \\
\hline P28 & 12 & $\mathrm{~F}$ & U.S. & 6 & $0^{*}$ & BRA & BRA \\
\hline $\mathrm{P} 30$ & 13 & $\mathrm{M}$ & U.S. & 8 & 0 & BRA & BRA \\
\hline P32 & 13 & $\mathrm{M}$ & U.S. & 8 & 0 & BRA & $\mathrm{ARG}$ \\
\hline P33 & 6 & $\mathrm{~F}$ & U.S. & 1 & 0 & BRA & USA \\
\hline
\end{tabular}

Table 1. Heritage Speakers -Detail

\begin{tabular}{|c|c|c|c|c|c|c|}
\hline \multicolumn{7}{|c|}{ Heritage Speakers: $N=33$} \\
\hline \multirow{2}{*}{ Gender } & \multicolumn{3}{|c|}{ Female } & \multicolumn{3}{|c|}{ Male } \\
\hline & \multicolumn{3}{|c|}{20} & \multicolumn{3}{|c|}{13} \\
\hline \multirow{2}{*}{ Age } & $\leq 7$ & \multicolumn{2}{|c|}{$7<$ Age $\leq 12$} & $>12$ & Mean & $\mathrm{SD}$ \\
\hline & 9 & \multicolumn{2}{|c|}{15} & 9 & 10.12 & 3.08 \\
\hline \multirow{3}{*}{ Place of Birth } & \multicolumn{3}{|c|}{ United States } & \multicolumn{3}{|c|}{ Brazil } \\
\hline & \multicolumn{3}{|c|}{25} & \multicolumn{3}{|c|}{7} \\
\hline & Both BR & Fa. NOR & & $\mathrm{ARG}$ & Fa. PER & Fa. FR \\
\hline Parents Place of Birth & 27 & 1 & & 2 & 1 & 2 \\
\hline
\end{tabular}

Table 2. Heritage Speakers - Summary 
Participant P8 was born in Brazil, but came to the United States at 3 months of age, and was hence counted as pertaining to the group of participants born in the United States. The remaining 23 participants were born in the United States. Siblings were included as a way of looking for variation in language use within the same family context, and probable evidence for developmental stages in the heritage language. The following pairs of participants are siblings: P2 and P3, P5 and P6, P7 and P8, P9 and P10, P13 and P14, P15 and $\mathbf{P 1 9}, \mathbf{P 2 2}$ and $\mathbf{P 2 3}$. The last pair belongs to the group of heritage speakers who immigrated at a later age. Participant P29 could not be found to take part in the second interview, and participant P31 did not display sufficient proficiency to either elaborate or answer to questions, therefore the results have not been included in the final analysis.

In addition to fluency in L1, gender, ethnicity, regional provenance of the family, and social-economic status were considered while selecting participants, so as to account for socio-linguistic variables which might influence language use. Sixty percent (60\%) of participants are females. Seven participants are "mestiços" - a term that indicates indigenous or African presence at some point in the family history. Two participants are children of "Nissei" parents (the children of Japanese who immigrated to Brazil). Eight participants come from lower income families, and ten participants come from more afluent families (selfreported annual income $>\mathrm{U} \$ 130,000$, and $>\mathrm{U} \$ 250,000$ ). All five (5) geographic regions of Brazil were represented in the study.

Religion is a prominent factor in Brazil, and is likely to influence language use - the only heritage speakers I have heard using the second person plural vós in Brazilian Portuguese are children of Evangelical families - so religious diversity was also taken into account.

All participants in this investigation have been selected crucially on the basis of being heritage speakers of Portuguese whose language acquisition process qualifies either under sequential bilingualism in childhood, or under simultaneous bilingualism, as defined in Rothman (2009). In the case of this set of participants, simultaneous bilingualism refers 
mostly to having English linguistic input from older siblings, as this is the language of choice between siblings. Eldest children, as well as only children, are subject to sequential bilingualism in childhood, even when they are exposed to English at a very young age (i.e., starting schooling at age 2).

Fluency in both languages was determined by the researcher during a five to ten minute interview - a "chat" - held immediately before each meeting. While no particular test or scale was used to measure fluency, all participants were judged on the basis of being able to participate in conversation using complex structures such as WH- questions and complex clauses in both languages.

Two control groups have been included in the design of the experiment: one composed of ten monolingual children and adolescents, and one formed by twelve adults, late bilinguals, randomly chosen among the group of heritage speakers caregivers. The monolingual control group matches as close as possible the group of heritage speakers in what concerns age range, socio-economic status, and varieties of Brazilian Portuguese spoken. Monolinguals were recruited through friends in Brazil and this group's composition is shown in Table 3, and in Table 4 below.

\begin{tabular}{|c|c|c|c|c|}
\hline Participant & Gender & Age & Education & Birth Place \\
\hline PMo41 & F & 9 & 4 & BRA \\
\hline PMo42 & M & 5 & 1 & BRA \\
\hline PMo43 & F & 11 & 6 & BRA \\
\hline PMo34 & F & 8 & 4 & BRA \\
\hline PMo45 & F & 8 & 2 & BRA \\
\hline PMo46 & M & 8 & 4 & BRA \\
\hline PMo47 & M & 13 & 7 & BRA \\
\hline PMo48 & M & 13 & 8 & BRA \\
\hline PMo49 & F & 7 & 2 & BRA \\
\hline PMo50 & M & 9 & 3 & BRA \\
\hline
\end{tabular}

Table 3. Monolingual Control Group - Detail 


\begin{tabular}{|c|c|c|c|c|c|}
\hline \multicolumn{3}{|c|}{ Monolinguals: $\mathbf{N}=\mathbf{1 0}$} \\
\hline \multirow{2}{*}{ Gender } & \multicolumn{2}{|c|}{ Female } & \multicolumn{3}{c|}{ Male } \\
\cline { 2 - 6 } & \multicolumn{3}{|c|}{5} & \multicolumn{3}{c|}{5} \\
\hline \multirow{2}{*}{ Age } & $\leq 7$ & $7<$ Age $\leq 12$ & $>12$ & Mean & SD \\
\cline { 2 - 6 } & 2 & 6 & 2 & 9.1 & 2.43 \\
\hline
\end{tabular}

Table 4. Monolingual Control Group - Summary

The second control group was included in the experiment to provide additional evidence to the claim that P-stranding is not found in the linguistic input these young heritage speakers receive in Brazilian Portuguese. The group was constituted having diversity of socio-economic status and varieties of Brazilian Portuguese spoken in mind, as described in Table 5, and in Table 6. In addition, the second control group also samples linguistic input from other "providers", such grandparents, other close relatives, and adult friends.

\begin{tabular}{|c|c|c|c|}
\hline \multicolumn{4}{|c|}{ Bilingual Adults - Caregivers: $\mathrm{N}=12$} \\
\hline \multirow{2}{*}{ Gender } & \multicolumn{2}{|c|}{ Female } & Male \\
\hline & \multicolumn{2}{|l|}{8} & 4 \\
\hline \multirow{2}{*}{ Age } & Range & Mean & Mean AOA \\
\hline & $39 \leq$ Age $\leq 68$ & 47.08 & 33.42 \\
\hline \multirow{2}{*}{ Length-of-Residence } & \multicolumn{2}{|c|}{$\leq 12$ years } & 12 years \\
\hline & \multicolumn{2}{|c|}{7} & 5 \\
\hline \multirow{2}{*}{ Education } & BS & MS & $\mathrm{PhD}$ \\
\hline & 5 & 6 & 1 \\
\hline
\end{tabular}

Table 5. Caregivers - Summary

\begin{tabular}{|c|c|c|c|c|c|c|}
\hline Participant & Gender & Age & Education & Birth Place & AOA & Length-Of-Stay \\
\hline PAd51 & F & 46 & 20 & BRA & 30 & 16 \\
\hline PAd52 & F & 49 & 30 & BRA & 46 & 3 \\
\hline PAd53 & F & 48 & 30 & BRA & 22 & 26 \\
\hline PAd54 & F & 39 & 20 & BRA & 28 & 11 \\
\hline PAd55 & F & 42 & 30 & BRA & 28 & 14 \\
\hline PAd56 & M & 42 & 20 & BRA & 29 & 14 \\
\hline PAd57 & M & 43 & 30 & BRA & 30 & 12 \\
\hline PAd58 & M & 44 & 30 & BRA & 29 & 12 \\
\hline PAd59 & F & 68 & 40 & BRA & 50 & 17 \\
\hline PAd60 & M & 43 & 30 & BRA & 31 & 12 \\
\hline PAd61 & F & 59 & 20 & BRA & 48 & 11 \\
\hline PAd62 & F & 42 & 20 & BRA & 30 & 12 \\
\hline
\end{tabular}

Table 6. Bilingual Adults - Caregivers - Detail 


\subsection{Experiment and Tasks}

The experiment consisted of two interviews, one in Portuguese, one in English, each containing two tasks: an elicited production task - the 'WH-Game/QU-game'- and a grammaticality judgment task, the 'Puppet Game'. Elicited-production tasks are frequently used in research with children, and are designed to elicit the production of a particular syntactic structure, in the broader context of a game or of a story (McDaniel 1996, 77). Elicited production tasks must be felicitous in order to be successful, and piloting the experiment is of extreme importance to ensure the desired outcome (McDaniel 1996, 85-88). Elicited production tasks do not provide the participant with any preset choices, allowing them to offer their own conception of what the target structure should be.

Grammaticality judgment tasks consist in "making a bipolar judgment" (McDaniel 1996, 211), about the accuracy of a particular structure. Grammaticality judgment tasks give the participant a limited number of options, which enables the researcher to formulate a clearer conception of what the child's grammar is, since in elicited-production tasks the child might have knowledge of the target structure, but simply choose not to use it, favoring an alternative structure instead.

Because many younger speakers took part in this investigation, it was primordial to try and develop tasks which would be interesting and fun enough to keep their focus, which could minimize the anxiety burden of "being tested", and which had the potential for promoting language production as faithful as possible to that of naturalistic speech contexts: four "games" were used as tasks. The word "games" made participants a lot more curious and interested in the experiment.

Conducting the first interview in Portuguese avoided priming effects from English, where P-stranding is the preferred solution. The same purpose, that is, avoiding priming effects, was what determined the sequencing of the two tasks (games) in each interview: the elicitation task was performed first, followed by the grammaticality judgment task. The study was divided into three phases: piloting, phase 1, and phase 2. Piloting was used to test games, 
materials, and instrument. Phase 1 and phase $\mathbf{2}$ were used to determine whether there would be differences in the outcome if participants performed tasks in both languages on the same day as opposed to performing tasks in each language 8 days apart.

\subsubsection{Instrument}

Sentences used in both games were structured as follows: only prepositions attested as highly frequent in both languages were used: in/em, with/com, to/para(pra) - com, about/sobre - de, on/em, for/para (pra), at/de, of/de (Borba, 1980). The complex preposition after/"atrás + de" was included with the intent of investigating how did the 4 groups of speakers would react when faced with the task of moving a PP containing a complex preposition (an adverb plus a preposition), as head of the phrase.

All verbs selected are also highly frequent in both languages, and related to children's and adolescents' everyday activities, such as: to like/gostar, to run/correr, to eat/comer, to be/ser - estar, to go out (with)/namorar, etc. All sentences used verb tense, aspect, and mood which exist in both languages and which are highly frequent, the present simple indicative, the present progressive, and the past perfective indicative, respectively. The verb to like/gostar, selects the preposition de, in Portuguese (which can behave as either a preposition or as a complementizer). Besides the above, verbs and prepositions were also chosen based on which WH-/QU- words they select, so that a variety of them would be part of the instrument.

Brazilian Portuguese is known for clipped and shortened forms in colloquial language, and in children's language: these were the forms used (i.e., (es)tá, $p(a) r a$, etc). Proper names used in the English sentences are names from TV shows which are very popular among young viewers in the US. Proper names used in the Portuguese sentences are all names of characters from Monica's Gang, a much beloved comic book in Brazil. All of the above aimed at inducing a sense of familiarity between the participants, the researcher, and the tasks, so as to reduce the testing effect and to encourage participants to use language as they would in naturalistic environments. 


\subsubsection{The 'QU- Game/WH- Game'}

The 'WH- Game/QU- Game' consists in eliciting $W H$ - question structures ( $Q U$ questions, in Portuguese) from the participants (elicited imitation). The researcher reads one sentence where either the NP which is the complement to the PP is either missing, or is not clear because its determiner particle is a demonstrative pronoun, as in (43), illustrated in Figure 17, and in (44), illustrated in Figure 18, and in (45) and (46), illustrated respectively in Figure 19 and in Figure 20:

(43) Mary talked to...

TARGET: Who did Mary talk to?
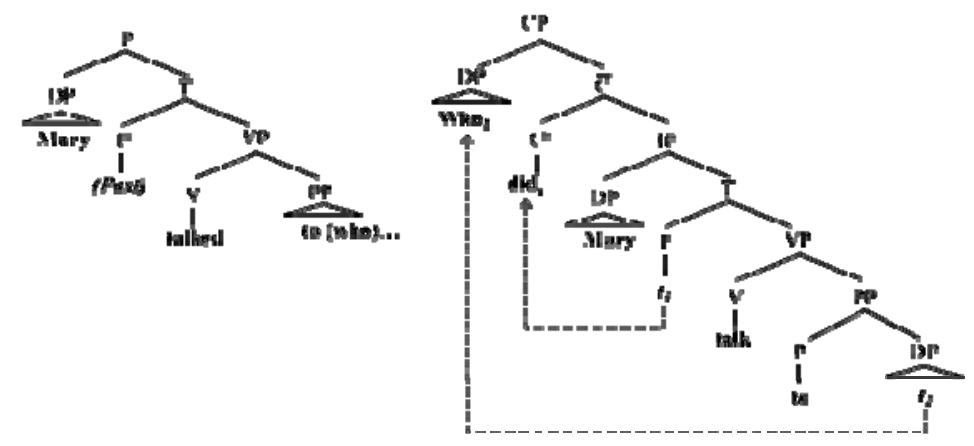

Figure 17. Base-form and Interrogative Form in (43)

(44) John is playing with that girl.

TARGET: Which girl is John playing with?

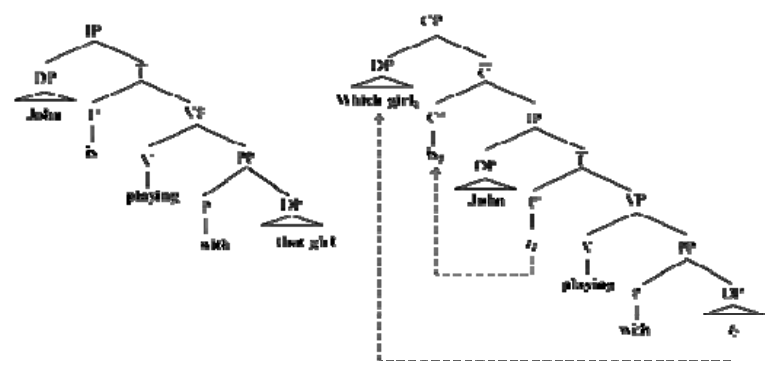

Figure 18. Base-Form and Interrogative Form in (44)

(45) A Maria falou com...

\section{A. F. Maria talked (3rd.S. Perf.) to/with...}

TARGET: Com quem (que) a Maria falou? / With who(m) did Mary talk?

*Quem (que) a Maria falou com? / *Who did Mary talk with? 


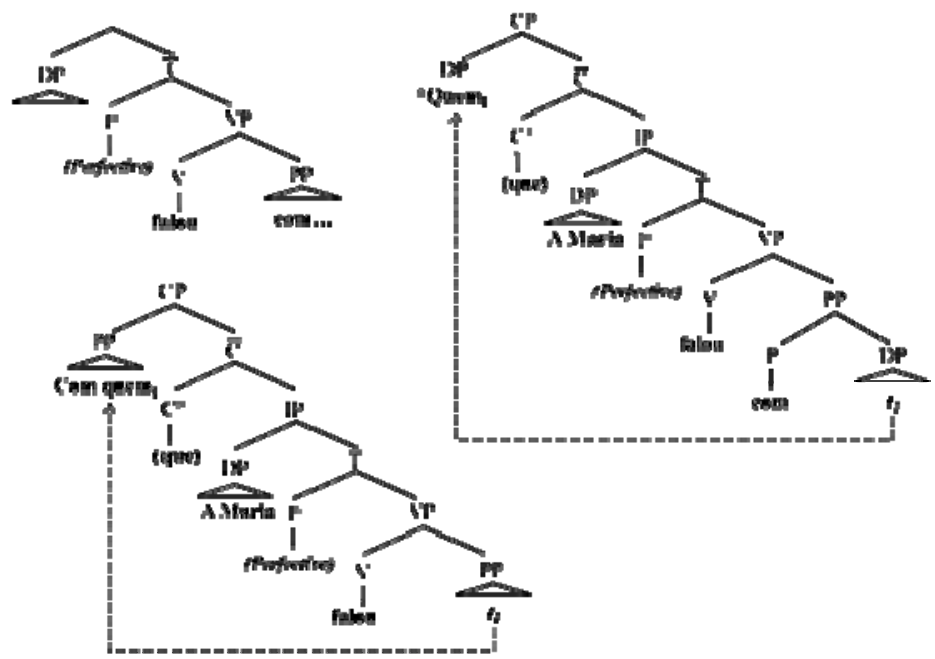

Figure 19. Base Form and Interrogative Forms in (45)

(46) $\mathrm{O}$

\section{A. M. João is playing(Gerund) with that ball...}

TARGET: Com qual bola o João (es)tá jogando? / *With which ball is João playing?

Qual bola (que) o João tá jogando com? *Which ball is João playing with?

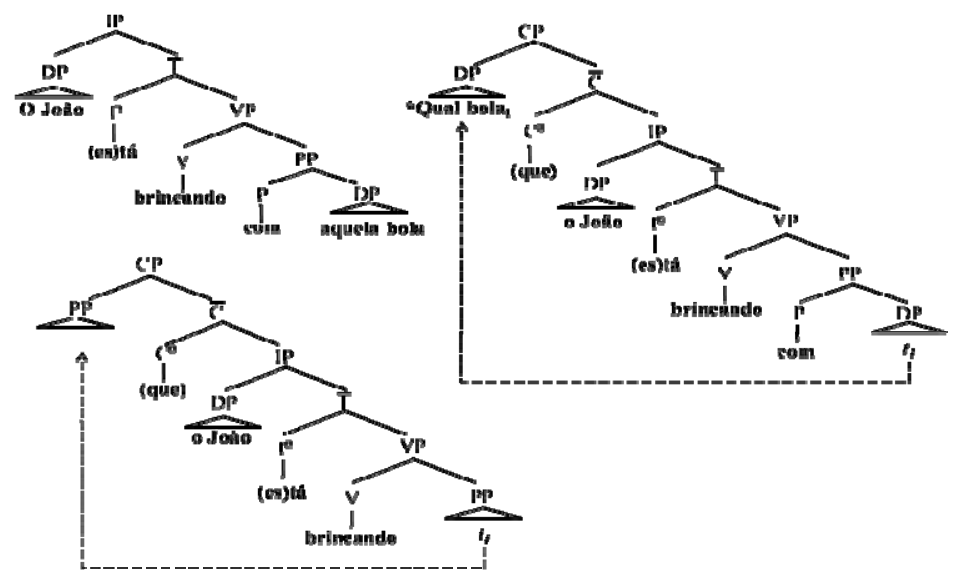

Figure 20. Base Form and Interrogative Forms in (46)

The combination of the two types of sentences used to elicit the target structure, plus the "look-alike" filler sentences, had the purpose of counterbalancing for fatigue effects.

The 'WH- Game/QU- Game' contains thirty (30) sentences: sixteen (16) sentences which test the target structure, four (4) sentences containing PPs which form an island with their 
complement DP, and hence cannot be moved - such as the ones shown in (41) and (42), and illustrated in Figure 13, Figure 14, Figure 15, and Figure 16, and ten (10) sentences which are "look-alike" fillers. The filler sentences elicit the production of interrogatives which, albeit similar to the target words, either do not contain a prepositional phrase, or contain complementizer phrase. In addition, two out of the sixteen (16) target sentences contain the verb "to like/gostar", a verb that selects a prepositional complement in Portuguese, but not in English. One of the target sentences contains the phrase "running after/ correndo atrás de", which contains a complex preposition in Portuguese.

Participants were told that they would hear researcher read one of two types of sentences: one where part of the information was missing, and another where researcher would point out at someone/something which was not in sight. Participant should then come up with a question in order to find out the missing piece of information, or who/what was being pointed at. Researcher would then answer the question participant had formulated. Researcher modeled task twice before starting, and more times if participants required so. Participants were told that the sentence could be repeated if need be, and they were encouraged to maintain as much of the original sentence as possible in the question they came up with.

Both sets of sentences, English and Portuguese, were scrambled by a computergenerated randomization algorithm, as a way to counterbalance for practice effects.

\subsubsection{The 'Puppet Game'}

The 'Puppet Game' is a grammaticality judgment experiment, during which each participant listens to fifteen (16) pairs of sentences uttered by two puppets. Target sentences are variations of the same $\mathrm{WH}-/ \mathrm{QU}$ - interrogative, one where $\mathrm{P}$ is pied-piped along with its WH/QU- complement, and the other where P is left stranded, as shown in (47), (48), (49), and (50), illustrated in Figure 21, Figure 22, Figure 23, and Figure 24: 
(47) Puppet 1: Who is Carly going to the movies with?

(48) Puppet 2:*With who is Carly going to the movies?

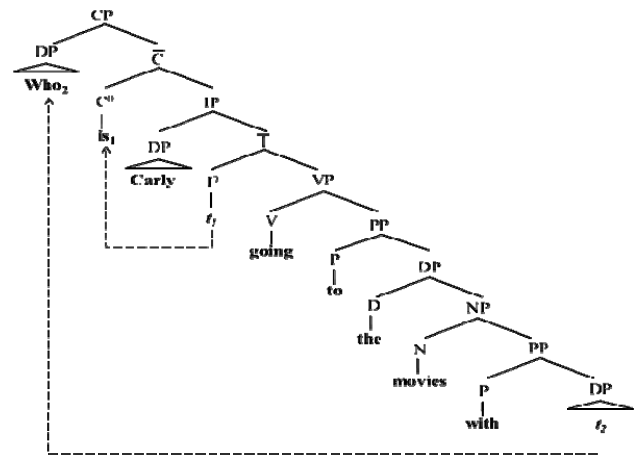

Figure 21. P-stranding in (47)

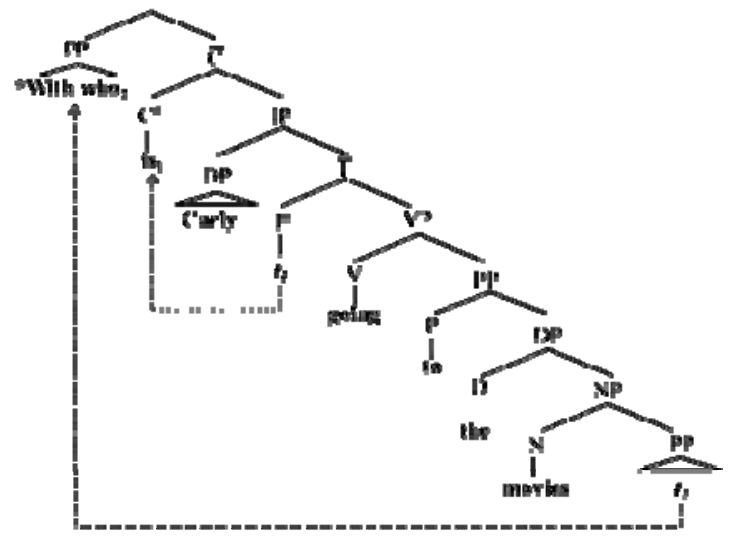

Figure 22. PiP in (48)

(49) Puppet 1: Com quem (que) a Mônica (es)tá indo ao cinema? With who(m) (that) D.A.F. Mônica is going to+the movies?

(50) Puppet 2: *Quem (que) a Mônica (es)tá indo ao cinema com? *Who (that) D.A.F Mônica is going to+the movies with? 


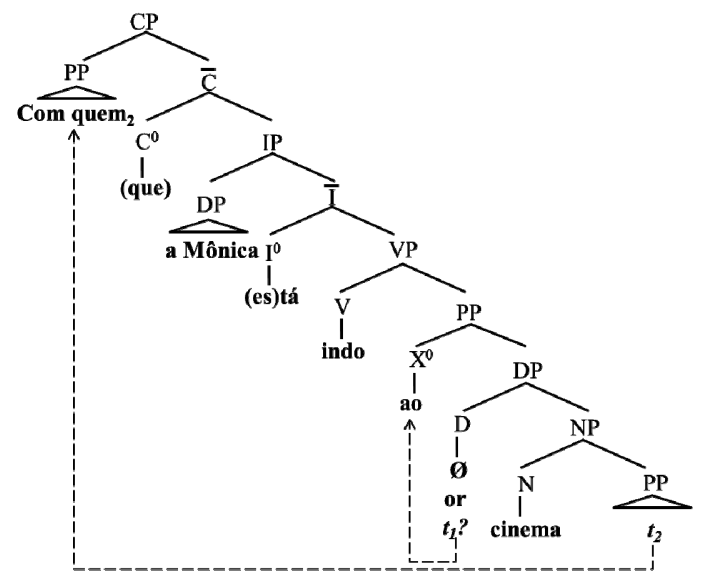

Figure 23. PiP in (49)

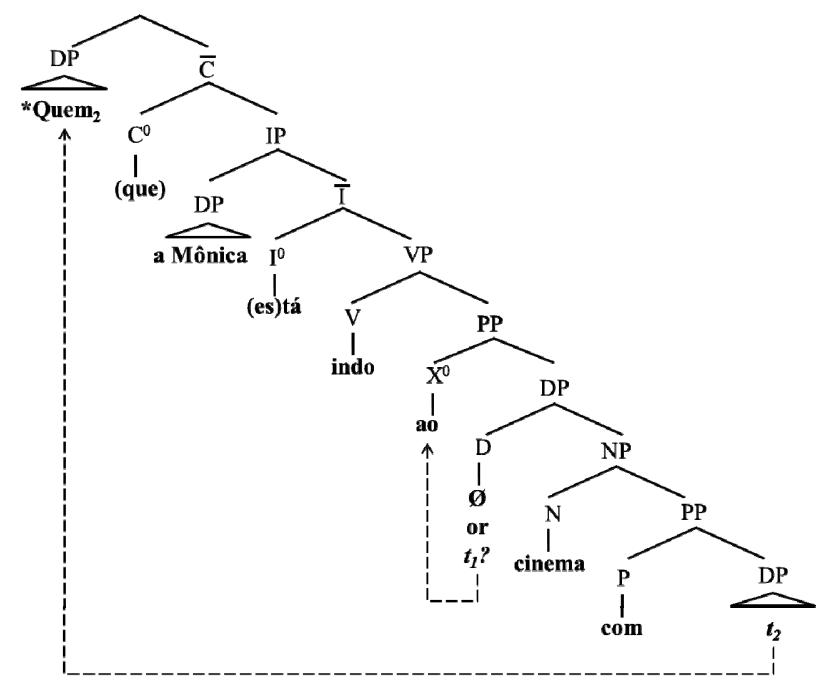

Figure 24. P-stranding in (50)

Four (4) pairs of sentences are ungrammatical in both the pied-piped and in the Pstranded variations, to test for systematicity, as shown in (41) and (42), illustrated in Figure 13, Figure 14, Figure 15, and Figure 16, chapter 3.

In addition, there are ten (10) filler sentences, accounting for 20 pairs in all. Filler sentences are pairs of WH-/QU- interrogatives and in-situ interrogatives, as in (51), (52), (53), (54), illustrated in Figure 25 and in Figure 26. All sentences are scrambled using a computergenerated randomizing algorithm. 
(51) Puppet 1: What did Fred say?

(52) Puppet 2: Fred said what?
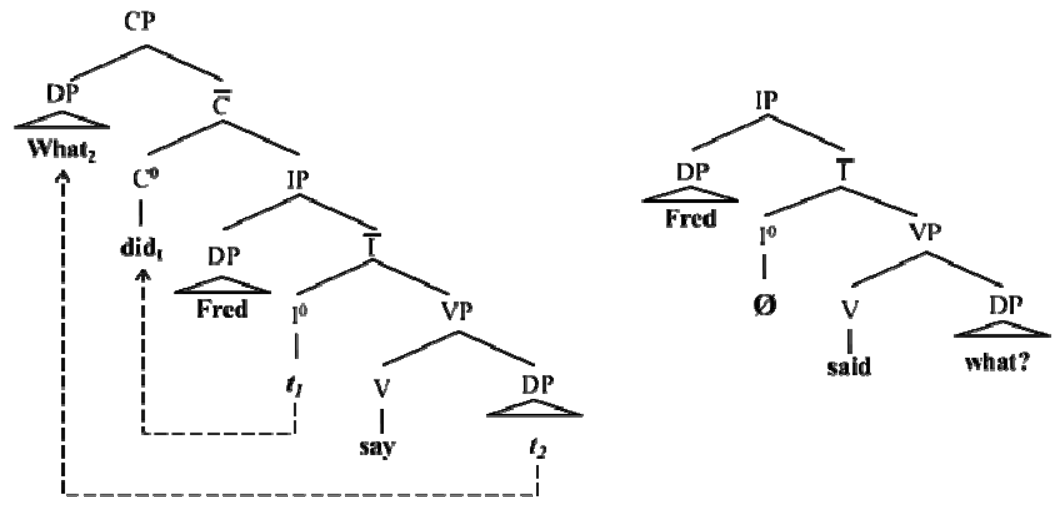

Figure 25. Filler Sentences - WH- movement and in situ in (51) and (52)

(53) Puppet 1: O que (que) a Mônica falou?

D.A.M what (did) (that) D.A.F. Mônica say $\left(3^{\text {rd }}\right.$ S. Perf.)?

(54) Puppet 2: A Mônica falou o que?

D.A.F. Mônica $\operatorname{say}\left(3^{\text {rd }}\right.$ S. Perf. $)$ D.A.M. what?

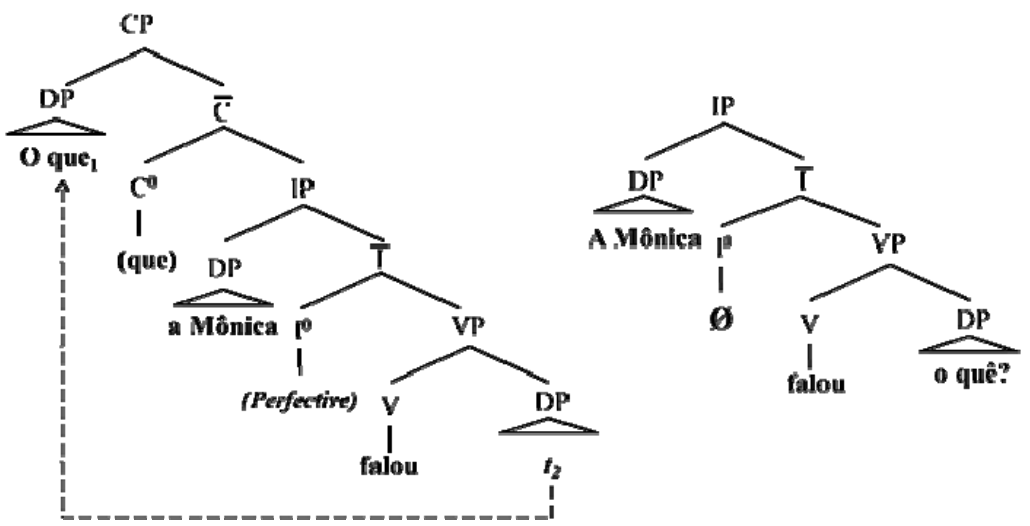

Figure 26. Filler Sentences - QU- movement and in situ in (53) and (54)

There were 2 puppets: a girl puppet, Mimi, and a boy puppet, Dudu (CV sequences and reduplication of a syllable to create a nickname are common practices in Brazil); both are bilingual children. The first puppet would utter one variant of a sentence, and the second puppet would utter the second variant. Participants were instructed to say the name and give out a piece of chocolate to the puppet who uttered a well-formed sentence in the target 
language. If both puppets utter well-formed sentences, participants are instructed to say both puppets' names and also to give one piece of chocolate to each of them - this avoids conflict in the filler sentences. If both puppets utter ill-formed sentences, participants are instructed to say "no one" and to give out no pieces of chocolate - avoiding conflict in ungrammatical pairs of sentences. In other words, participants could choose from an array of four (4) possible answers.

\subsection{Procedures}

\subsubsection{Piloting}

Piloting was paramount to test the design and materials of the games. It lasted three months, and it was first done in classroom, in two separate occasions, with thirteen heritage speakers, during each session. Subsequently, a complete version of the four tasks was applied to three adults (female -67 , female -41 , male -42 ), then to two heritage speakers ( 1 male 11, 1 female - 5), mimicking the actual experiment. Results of piloting were recorded in writing.

The main objective while piloting the 'WH-/QU- Game' was to determine whether participants would understand the purpose of the game just by listening to the sentences, or whether a visual aid would have to be introduced to facilitate comprehension. Results were very consistent, showing that the task could be satisfactorily performed with no additional stimuli, which was one of the goals of this study's conceptual design: to try and avoid the involvement of cognitive processes not directly related with language production, such as reading or other visual processes. Interestingly, adults displayed a slightly greater difficulty in understanding the task at hand.

In regards to the 'Puppet Game', many aspects were tested during piloting, among which: what kind of puppets would minimize empathy effects among participants, avoiding bias towards a single puppet; how to hide the chocolate pieces in order to avoid that participants to count how many pieces each puppet had; how to sequence questions in a way 
that would prevent participants from looking for patterns; in special, how to explain the game in a way which would be engaging to both younger and older speakers, in other words, how to include the puppets in the experiment without drawing a negative reaction from older speakers. In the first attempt, the puppets were humans, a boy and a girl, but many participants paid too much attention to physical features, displaying greater sympathy for one of the puppets. A cow and a pig substituted, but then a good number of participants did not like cows, or did not like pigs, or thought pigs were smarter than cows, etc. Finally, the decision was made for two identical brown bears, who were brother and sister, heritage speakers of BP. The sister wore a pink scarf.

As for the setup of the 'Puppet Game', try outs were made using two bowls, one blue for the boy bear, one pink for the girl bear, then using 3 identical green bowls, one for the participant, and one for each puppet. A white screen with two windows with the puppets' names was added later on during piloting to avoid counting of the chocolate pieces. As a last step, curtains were added to each window as participants would still try to count chocolate pieces through the windows. Puppets' names went from Mat and Kat to Dudu and Mimi. Setup for the game is shown in Figure 27.

The explanation of the game that was deemed the best suited to ages was as follows: researchers needed assistants, but had no funds to pay for two of them; so they found the two bears, who agreed to work for the love of science (and of chocolate). The two bears were bilinguals, heritage speakers of BP, and they needed the participant to tell them whether they spoke "good Portuguese" (or good English). 


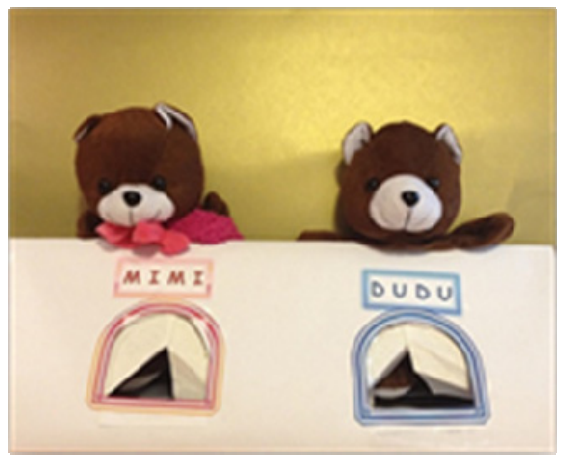

Figure 27. Dudu and Mimi - 'Puppet Game'

The original idea was that, during both games (WH- and puppet), researcher would read sentences from an iPad or similar tablet, which is lighter than a laptop, and does not require booting procedures, allowing for reduced setup time, which is a huge issue when working with such young speakers outside of a laboratory context. Piloting showed that it was impossible for researcher to slide fingers on the tablet's screen while "wearing" the puppets, but holding down a key in the keyboard was feasible, so Mimi, the "girl" puppet, became the slide changer, and the table was substituted with a laptop.

\subsubsection{Linguistic Competence}

At the beginning of each interview, researcher told participants that the purpose of the present study was to document how young speakers use Portuguese in the US. Researchers asked casual questions to each participant, such as: name, age, grade, what school does the participant attend, what participant likes to do most, what are participant's hobbies, favorite subjects, whether they have family in Brazil, and where are their parents from; participants are given the option to ask questions to researcher. The activity serves two purposes: first, to "break the ice" between researcher and participant, and, to provide a general idea of the participant's linguistic competence in each language. The pre-task interview activity lasted between two and ten minutes. 


\subsubsection{Phase 1 and Phase 2}

The subdivision in phases aimed at testing possible differences in outcome as a result of performing tasks in different languages in the same day or 8 days apart, as well as aspects such as participant fatigue, effects of novelty, etc. During phase 1, 12 participants performed both interviews in the same day. They were interviewed first in Portuguese then, after a half an hour interval, in English. During phase 2, the remaining participants, $\mathrm{N}=22$, performed tasks in Portuguese, then eight days later in English.

The order of the interviews, Portuguese followed by English, avoided priming effects, since P-stranding is not part of BP grammar.

\subsubsection{Interviews}

Interviews were conducted at participants' convenience: in their homes, in researchers' home offices, and in local libraries. Participants were given the option of stop playing the games at any time, and of having parent/caregiver present in the room during the games.

If participant elected not to have caregiver in the room during the interview, caregivers were given a language history questionnaire to fill out, to provide additional information about participants' language history and about how languages are used in the family's dynamic. Otherwise, caregivers were given the option to fill out the questionnaire at their earliest convenience and forward it to the researcher.

All participants were told that the purpose of the present study was not to test their Portuguese, rather to document how these young bilinguals use Portuguese in South Florida. Following this short explanation, the researcher talked with participants about their families and their school lives. The researcher then explained that the first interview would be conducted in Portuguese, and that the first game was called the $Q U-(W H-$ in English) game. During the game, the researcher would read one of two types of sentences from the computer screen: an incomplete sentence (as in sentence (43) and, described in chapter 4.2.2), or a 
complete sentence pointing out at something/someone not visible to participant (shown in (44), also described in chapter 4.2.2): participants' task was to try and find out the piece of information that was missing, or what/who researcher was pointing at by coming up with a question using as many elements as possible from the original sentence. Task was modeled twice to each participant.

After a fifteen-minute break, participants played the 'Puppet Game'. The researcher explained that the bears wanted the participant to be their teacher, and that the participant had to give his/her true judgment about each question uttered, otherwise puppets would not find out whether they spoke Portuguese (and English) "correctly". The game was modeled twice to each participant, and all participants had the choice to ask for further modeling.

Counterbalancing was done "online" during the 'Puppet Game', using the Latin square method, taking into account the following variables: which puppet spoke first, which puppet uttered the grammatically correct sentence, which type of sentence was uttered first (i.e., the grammatical or the ungrammatical).

All participants were given the option of skipping questions or withdrawing participation at any time during both interviews.

The exact same methods were adhered to during the interviews with both control groups, singling out the fact that these two groups were interviewed in Portuguese only.

\subsection{Materials}

Interviews were recorded using a microphone/recorder, SONY IC RECORDER ICDSX712, using the noise reduction filter setting. Files were saved in MP3 (compressed) format, one file per participant, per interview - making up for two raw files per participant, the outcome of the Portuguese interview, and the outcome of the English interview. All files were subsequently uploaded to a desktop computer, tabulated and analyzed using both MS Excel 2010, and SPSS v.19. The original files were then stored and deleted from desktop computer. 
The researcher read sentences to the participants from the screen of a DELL INSPIRON laptop during both experimental tasks and during both interviews. The sentences in the instrument were sequenced, for each game, following a randomized sequence generated using RANDOM.ORG (http://www.random.org/). See http://www.random.org/ randomness/, for a detailed discussion of pseudo-random and true random numbers.

The grammaticality judgment task required two bear puppets, three opaque green plastic bowls, one white screen with two windows and curtains, and pieces of chocolate.

The responsible party (i.e., the parent or guardian present) filled out the L2 language history questionnaire, in electronic format, used for data-crossing with the information gathered during the interviews. The L2 Language History Questionnaire was adapted from the L2 Language History Questionnaire, version 2.0 (Li, Sepanski and Zhao, 2006). The authors surveyed 41 published language history questionnaires (Li, Sepanski and Zhao, 2006:202), before finalizing their version of the questionnaire.

The original questionnaire can be retrieved at: http://www.personal.psu.edu/pul8/ questionnaire/L2 questionnaire.html. The original questionnaire was conceived to retrieve the language history of an adult speaker, and hence modifications became necessary to reflect data which is relevant to the language history of a heritage speaker, including information on the language history of parents and caregivers. Moreover, (Li, Sepanski and Zhao, 2006)'s questionnaire does not include socio-economic information, which is deemed relevant to the present study, and was hence added to the original version.

\subsection{Coding and Analysis}

Results were analyzed from an inter-participant perspective, and cross-analyzed with data gathered from the Language History Questionnaire which legal guardians filled out.

One hundred percent (100\%) of raw data underwent intra-judge reliability checking, precision greater than $99 \%$ ( 8 in 6720 tokens). Inter-judge realiability checking was done in $50 \%$ of the data, precision greater than $99 \%$. Three types of sentences were analyzed: 


\begin{tabular}{|c|c|}
\hline Question Type & Code \\
\hline \hline Target Grammatical & TGT-GRA \\
\hline Target Ungrammatical & TGT-UNG \\
\hline Filler & FIL \\
\hline
\end{tabular}

Table 7. Types of Questions in Instrument

Table 8 and Table 9 show coding for the "QU-/WH- Game" and the 'Puppet Game':

\begin{tabular}{|c|c|}
\hline \multicolumn{2}{|c|}{ Coding QU-/WH- Game } \\
\hline Answer Type & Code \\
\hline \hline NO ANSWER & 0 \\
\hline P-Stranding & 1 \\
\hline Pied-Piping & 2 \\
\hline P-Deletion & 3 \\
\hline In situ & 4 \\
\hline Changed Base Strucuture & 5 \\
\hline Filler - Fronted QU/WH & 6 \\
\hline
\end{tabular}

Table 8. Coding for QU-/WH- game

\begin{tabular}{|c|c|}
\hline \multicolumn{2}{|c|}{ Coding 'Puppet Game' } \\
\hline Question Type & Code \\
\hline \hline NONE RIGHT & 0 \\
\hline P-Stranding & 1 \\
\hline Pied-Piping & 2 \\
\hline P-Deletion & 3 \\
\hline In situ & 4 \\
\hline BOTH RIGHT & 5 \\
\hline Filler - Fronted QU/WH & 6 \\
\hline
\end{tabular}

Table 9. Coding for 'Puppet Game'

\section{RESULTS AND DISCUSSION}

Thirty-three heritage speakers of Brazilian Portuguese were interviewed for the present study. The results from P2, P9, P29, and P31 were not tallied in the final count, in virtue of the following: P2 did not display the capability of producing questions with QUmovement in Portuguese. P9 did not produce enough samples, opting for skipping more than fifty percent of the tokens. P29 did not display enough proficiency in Portuguese. She did not understand instructions to the games, and she displayed signs of not possessing the necessary 
semantic knowledge to interpret sentences in the instrument. P31 could not be contacted for the second interview in American English.

The results of twenty-two heritage speakers born in Brazil, seven heritage speakers who immigrated to the US at age 6 or older, ten monolinguals interviewed in Brazil, and twelve caregivers, adult bilinguals, were tabulated in analyzed.

Among the control group of adult bilinguals (caregivers), PAd54 and Pad61 selfreported Portuguese as their dominant language; the remaining adults reported English as their dominant language. Participant P24, from the group of heritage speakers born in Brazil, was qualified as being dominant in Portuguese, on the basis of data gathered during interview and games, and of reported length-of-stay in the United States. Participant P33 was also qualified as having BP as her dominant language: during the interview in English, she asked repeatedly to "talk in Portuguese", although she displayed age appropriate proficiency in the English.

\subsection{Phase 1 vs. Phase 2}

While analysis showed that overall results suffered zero external impact due to the difference in structuring of the experiments in phases 1 and 2 (same day opposed to eightdays apart interviews), a couple of interesting, unexpected effects were detected. The participants interviewed during phase 1 behaved better and collaborated more actively during the interview in English than participants interviewed in phase 2, regardless of age. Younger participants interviewed during phase 2 had to be steered back to the task at hand several times during the second interview, but not during the first interview. Older participants interviewed during phase 2 gave visible signs of loss of interest in the task at hand during the second interview, but not during the first. Qualitative observations singled out the lack of novelty during the second interview as the most probable factor for such behavior: the participants already knew the games, as well as the puppets, therefore they lost interest. 
Fatigue, which had been anticipated as a probable problem for heritage speakers who took part in phase 1 of the experiment, did not become an issue.

\subsection{Results in Siblings}

In what concerns the sibling participants, no meaningful overall differences, in any direction, were found in the results produced by the following pairs:

\section{HS of BP born in the US}

$\begin{array}{ll}\text { P2 (male }-7 \text { years old }) & \text { P3 (male }-13 \text { years old) } \\ \text { P5 (female }-7 \text { years old) } & \text { P6 (male }-9 \text { years old) } \\ \text { P7 (female }-5 \text { years old) } & \text { P8 (male }-11 \text { years old) } \\ \text { P9 (female }-4 \text { years old) } & \text { P10 }(\text { female }-7 \text { years old }) \\ \text { P13 (male }-9 \text { years old) } & \text { P14 (male }-6 \text { years old) } \\ \text { P15 (female }-7 \text { years old) } & \text { P19 (female }-14 \text { years old) }\end{array}$

\section{HS of BP born in Brazil}

$$
\text { P22 (male }-12 \text { years old) P23 (male }-10 \text { years old) }
$$

In the pair of siblings P16 (female, 11 years old), P17 (male, 9 years old), however, results were highly contrasting: P16 produced 0/16 instances of P-stranding in the QU-game, while the younger sibling, P17, produced 7/16 instances of P-stranding, and the rest, 9/16, were instances of P-ellipsis. Actually, P16, as per discussion in chapter 5.3 below, shown in Table 11, produced 12/16 instances of PiP, and the remaining 4 were instances of P-ellipsis.

Besides gender and age, which do not appear to bear any weight on the use of preposition stranding, the other factor which could potentially account for such a distinction in the results of this pair of siblings would be that the older sibling has spent more time in Brazil than the younger sibling, also having had some schooling experience (approximately 3 months), but the younger sibling has not had this experience.

\footnotetext{
${ }^{3}$ P9 actually did not display the ability of producing WH-/QU- movement of any kind, resorting mostly to in-situ interrogatives, as per discussion in 5.
} 


\subsection{Results 'QU- game'}

Final results for the QU-game, sentences in which pied-piping was expected are summarized in Table 10, Table 11, Table 12, Table 13, and in Table 14, illustrated in Figure 28, Figure 29, Figure 30, Figure 31, and Figure 32, respectively:

\begin{tabular}{|l|l|}
\hline \multicolumn{1}{|c|}{ 'QU- game': Totals HS born in the US } & Tokens \\
\hline \hline Total P-strand. In expected pied-piping & 146 \\
\hline Total P-ellipsis in expected pied-piping & 98 \\
\hline Total Change Base Structure in expected pied-piping & 19 \\
\hline Total in situ in expected pied-piping & 32 \\
\hline Total NO ANSWER in expected pied-piping & 1 \\
\hline Total pied-piping in expected pied-piping & 56 \\
\hline In Total Tokens & $\mathbf{3 5 2}$ \\
\hline
\end{tabular}

Table 10. Answers in expected pied-piping - HS born in the US

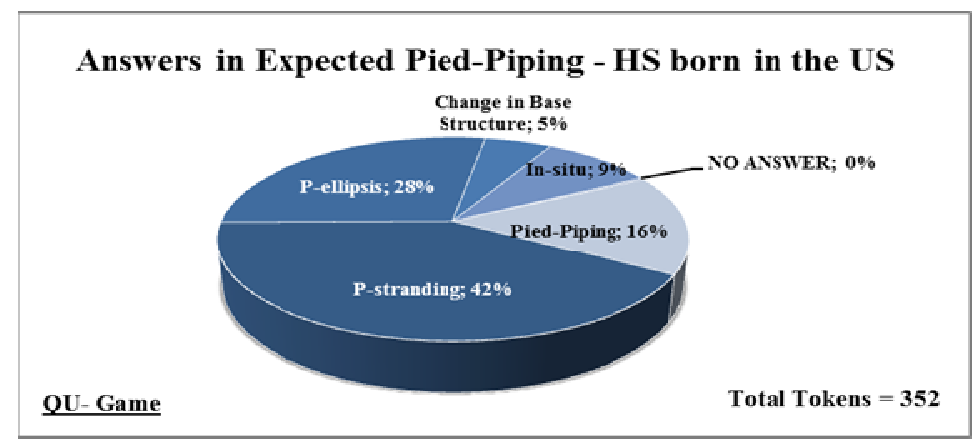

Figure 28. Answers in expected pied-piping - HS born in the US

Importantly, 34 out of the 56 total occurrences of PiP came from 3 participants only:

\begin{tabular}{|c|c|c|}
\hline Pied-piping occurrences in HS born in the US & Tokens & In Total Tokens \\
\hline Total Pied Piping from P16 & 12 & 16 \\
\hline Total Pied Piping from P18 & 14 & 16 \\
\hline Total Pied Piping from P28 & 8 & 16 \\
\hline Total Pied Piping Other Participants & 22 & 304 \\
\hline
\end{tabular}

Table 11. Pied-piping in HS born in the US 


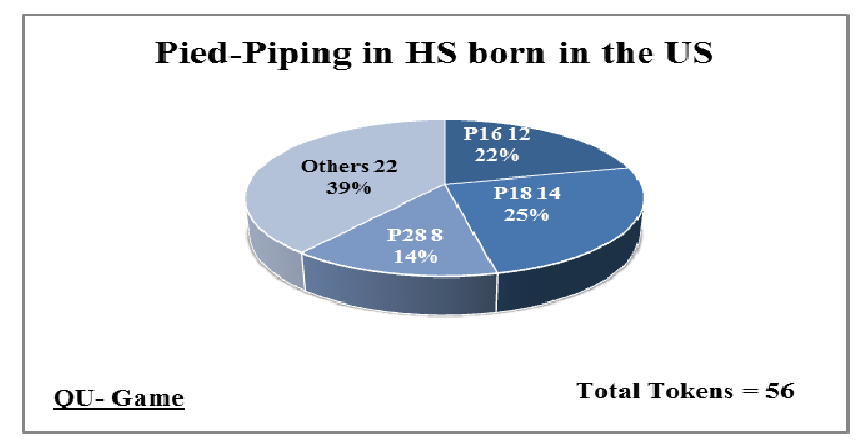

Figure 29. Pied-piping in HS born in the US

\begin{tabular}{|l|c|}
\hline \multicolumn{1}{|c|}{ 'QU- game': Totals HS born in BR } & Tokens \\
\hline \hline Total P-stranding in expected pied-piping & 1 \\
\hline Total P-ellipsis in expected pied-piping & 30 \\
\hline Total Change Base Structure in expected pied-piping & 1 \\
\hline Total In situ in expected pied-piping & 1 \\
\hline Total NO ANSWER in expected pied-piping & 0 \\
\hline Total pied-piping in expected pied-piping & 79 \\
\hline In Total Tokens & $\mathbf{1 1 2}$ \\
\hline
\end{tabular}

Table 12. Answers in expected pied-piping - HS born in Brazil

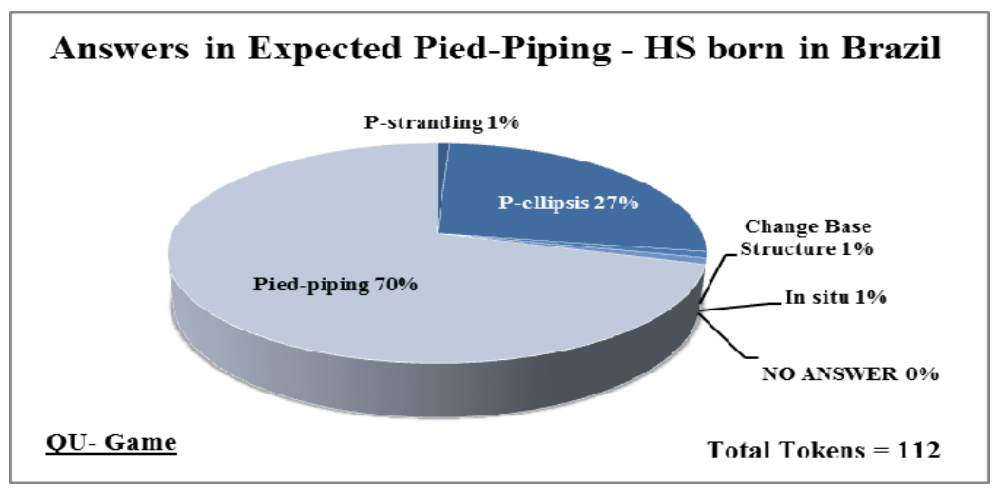

Figure 30. Answers in expected pied-piping - HS born in Brazil

\begin{tabular}{|l|c|}
\hline \multicolumn{1}{|c|}{ 'QU- game': Totals Monolinguals } & Tokens \\
\hline \hline Total P-strand. In expected pied-piping & 0 \\
\hline Total P-ellipsis in expected pied-piping & 34 \\
\hline Total Change Base Structure in expected pied-piping & 4 \\
\hline Total In situ in expected pied-piping & 24 \\
\hline Total NO ANSWER in expected pied-piping & 2 \\
\hline Total pied-piping in expected pied-piping & 96 \\
\hline In Total Tokens & $\mathbf{1 6 0}$ \\
\hline
\end{tabular}

Table 13. Answers in expected pied-piping - Monolinguals 


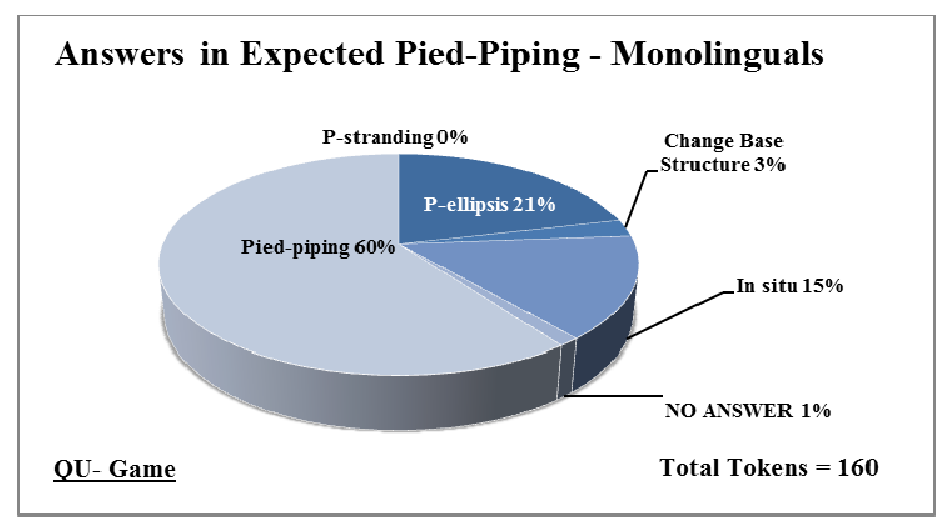

Figure 31. Answers in expected pied-piping - Monolinguals

\begin{tabular}{|l|c|}
\hline \multicolumn{1}{|c|}{ 'QU-game': Totals Bilingual Adults } & Tokens \\
\hline \hline Total P-strand. In expected pied-piping & 1 \\
\hline Total P-ellipsis in expected pied-piping & 13 \\
\hline Total Change Base Structure in expected pied-piping & 3 \\
\hline Total In situ in expected pied-piping & 2 \\
\hline Total NO ANSWER in expected pied-piping & 0 \\
\hline Total pied-piping in expected pied-piping & 173 \\
\hline In Total Tokens & 192 \\
\hline
\end{tabular}

Table 14. Answers in expected pied-piping - Bilingual Caregivers

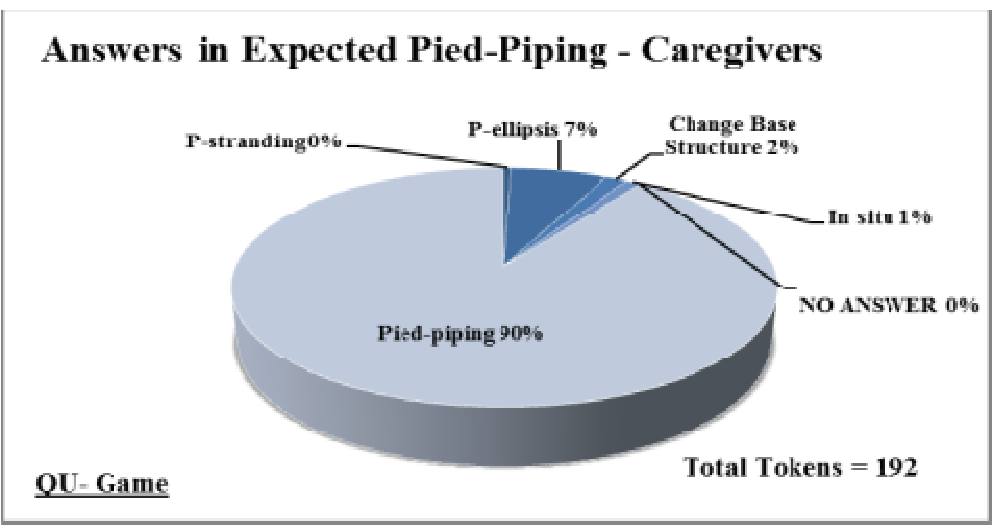

Figure 32. Answers in expected pied-piping - Bilingual Caregivers

The data in Table 10 provide evidence that $\mathrm{P}$-stranding is the preferred solution among heritage speakers of BP born in the US. The data also show that pied-piping is not the next preferred solution. Table 15 below summarizes the results for the QU-game in all instances in which pied-piping was be the expected solution: 


\begin{tabular}{|c|c|c|c|c|}
\hline $\begin{array}{l}\text { 'QU- game': Answers in Target } \\
\text { Pied-Piping }\end{array}$ & $\begin{array}{l}\text { HS born in } \\
\text { the US }\end{array}$ & $\begin{array}{c}\text { HS born in } \\
\text { Brazil }\end{array}$ & Monolinguals & Caregivers \\
\hline P-stranding & $42 \%$ & $1 \%$ & $0 \%$ & $0 \%$ \\
\hline P-ellipsis & $28 \%$ & $27 \%$ & $21 \%$ & $7 \%$ \\
\hline Change in Base Structure & $5 \%$ & $1 \%$ & $3 \%$ & $2 \%$ \\
\hline In situ & $9 \%$ & $1 \%$ & $15 \%$ & $1 \%$ \\
\hline NO ANSWER & $0 \%$ & $0 \%$ & $1 \%$ & $0 \%$ \\
\hline Pied-piping & $16 \%$ & $70 \%$ & $60 \%$ & $90 \%$ \\
\hline Total & $100 \%$ & $100 \%$ & $100 \%$ & $100 \%$ \\
\hline
\end{tabular}

Table 15. 'QU- game' - Summary of Answers in Expected Pied-Piping

A one-way between groups analysis of variance (ANOVA) was conducted to assess whether the use of P-stranding varied across the four groups in sentences where PiP was the expected structure. There was a statistically significant difference at the $p<.001$ level in Pstranding counts for the four groups: $\mathrm{F}(3,47)=17.58, \mathrm{p}<.001$. Post-hoc comparisons using Tukey HSD test indicated that the mean count for the group of HS born in the US (M=6.64, $\mathrm{SD}=4.78$ ), was significantly different from the mean counts for the group of HS born in Brazil, $(\mathrm{M}=.14, \mathrm{SD}=.39)$, from that for the group of monolinguals, $(\mathrm{M}=.00, \mathrm{SD}=.00)$, and from that for the group of adult caregivers $(\mathrm{M}=.08, \mathrm{SD}=.29)$. Post-hoc comparisons also indicated that the latter three groups did not display statistically significant differences between each other in the usage of P-stranding.

The numbers get yet more compelling when considering the data presented in Figure 29 above, which show that $61 \%$ of the $16 \%$ instances of pied-piping were actually produced by 3 heritage speakers only, P16, P18, and P28.

The data collected from these three participants are valuable, as they can be evidence for protracted acquisition, since all three belong to the group of older heritage speakers: P16 was $11, \mathrm{P} 18$ was 15 , and P28 was 12 , at the time of the interview. However, such finding is not corroborated by the data collected from other older participants, as shown in Table 16: 


\begin{tabular}{|l|c|c|}
\hline Older Participants & P-stranding & Pied-piping \\
\hline \hline P3 - 13 years old & 9 & 2 \\
\hline P11 - 12 years old & 6 & 1 \\
\hline P19 - 14 years old & 6 & 0 \\
\hline P30 - 13 years old & 7 & 1 \\
\hline P32 - 13 years old & 5 & 1 \\
\hline
\end{tabular}

Table 16. 'QU- game': Summary of Older HS

The data in Table 16 would leave open two possibilities: either the acquisition of PP movement in heritage speakers is protracted, and subject to internal individual differences in linguistic ability, or there is an external variable playing a role in the acquisition of PP movement in the case of participants P16, P18, and P28. By cross-analyzing the data collected from the answers given by the three participants during the pre-interview, with the data gathered from their language history questionnaires, one factor became salient: all three participants in question spend from 2 to 4 months in Brazil yearly. Moreover, P16 and P18 attended school in Brazil, although for short periods (3 to 6 months) only.

\subsubsection{Verbs that Select Prepositional Complements in BP but not in English}

Sentences QU-24 and QU-29 of the instrument have "gostar" (to like) as the main verb. In Brazilian Portuguese (but not in American English), "gostar" selects a prepositional complement. The questions produced by the heritage speakers born in the US in response to these two sentences followed the overall pattern of the other sentences containing the target structure: 10 instances of P-stranding and 8 instances of P-ellipsis (in a total of 22 tokens) were produced for QU-24, and 8 instances of P-stranding and 11 instances of P-ellipsis (in 22 tokens), were produced for QU-29.

In a qualitative observation, many of the instances of in situ QU- structures produced by all four groups appeared to be more closely associated with either test anxiety, or with a lack of understanding of the rules of the "games", than with the reasons described in the literature for the use of in situ interrogatives in BP, such as echo questions and pragmatic nuances, as described in chapter 3.2, Hypothesis 2. The observation is interesting when paired 
with findings by Grolla (Grolla, 2005), who reports that speakers of BP (children), acquire in situ interrogatives much later than interrogatives with QU- movement. In the present experiment, P2 (4.3 years old), for example, used in situ interrogatives in 94\% (15 out of 16 tokens), of the instances in which pied-piping was expected in Portuguese, although she showed the ability of producing instances of movement in English, during the games, and in Portuguese, during the pre-interview. The results from P2 were not included in the final count.

\subsubsection{P-ellipsis}

The percentage of interrogatives produced by heritage speakers using P-ellipsis was greater than anticipated. All the more surprising was the fact that all three groups of young speakers, HS born in the US, HS born in Brazil, and Brazilian monolinguals used ellipsis at a similar rate $-28 \%, 27 \%$, and $21 \%$, respectively - regardless of the fact that these three groups diverge sharply in their preferred solution for QU- interrogatives. Moreover, P-ellipsis was also seen in the group of adult bilinguals, albeit at a smaller rate, $7 \%$.

Interestingly enough, a more detailed analysis of the usage of P-ellipsis by all four groups of participants, shown in Table 17, demonstrates a clear tendency, overall (even if not so pronounced among adult bilinguals, ellipsis was the second more common choice of structure among this group), to use ellipsis in sentences where the prepositional head is a suppletive form of the kind preposition combined with a demonstrative pronoun:

\begin{tabular}{|c|c|c|c|c|}
\hline P-ellipsis in Expected PiP & HS born in the US & $\begin{array}{c}\text { HS born in } \\
\text { Brazil } \\
\end{array}$ & Monolinguals & $\begin{array}{c}\text { Adult } \\
\text { Bilinguals } \\
\end{array}$ \\
\hline $\begin{array}{c}\text { QU10: } \text { em }+ \text { aquela casa } \\
(\text { in }+ \text { that } \text { house })\end{array}$ & 14 & 5 & 8 & 2 \\
\hline $\begin{array}{c}\text { QU12: em }+ \text { aquela árvore } \\
(\text { on }+ \text { that } \text { tree })\end{array}$ & 13 & 4 & 8 & 6 \\
\hline $\begin{aligned} \text { Qu16: } & \text { de }+ \text { aquele filme } \\
& (\text { of }+ \text { that } \text { movie })\end{aligned}$ & 8 & 4 & 5 & 1 \\
\hline $\begin{array}{c}\text { QU27: de + aquele vídeo-gaime } \\
\text { (of }+ \text { that } \text { video-game })\end{array}$ & 11 & 3 & 5 & 2 \\
\hline 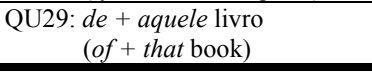 & 11 & 4 & 7 & 1 \\
\hline TOTAL PARTICIPANTS & 22 & 7 & 10 & 12 \\
\hline
\end{tabular}

Table 17. Summary of P-ellipsis Usage 
The data from the 'QU- game' for the group of caregivers provided additional evidence to the discussion brought forth in chapter 1.1, that the use of P-stranding is not present in the linguistic input (in Portuguese), that heritage speakers receive in South Florida: caregivers produced pied-piping in $90 \%$ of the instances where it was the expected solution, and did not produce one single instance of p-stranding: $0 \%$ of total tokens.

\subsubsection{Ungrammatical Sentences}

In regards to the ungrammatical sentences, findings are reported in Table 18, Table 19, Table 20, and in Table 21, also illustrated in Figure 33, Figure 34, Figure 35, and in Figure 36 below. The findings provide evidence of a preference, by all four groups, towards changing the base-structure of the sentence when formulating an interrogative in cases in which PP movement would implicate in an ill-formed (ungrammatical) sentence (as the ones exemplified in chapter 3.2, sentences (41) and (42), illustrated in Figure 13, in Figure 14, Figure 15, and in Figure 16).

It is worthwhile pointing out that the results for all four groups of participants converge in regards to the ungrammatical sentences, which provides evidence to the fact that speakers are aware that there is 'something' in these particular sentences which bars PP movement when forming a QU-interrogative. The awareness of instances in which PP movement in any shape is barred, in turn, is evidence that PP movement is systematic.

\begin{tabular}{|l|c|}
\hline \multicolumn{1}{|c|}{ Ungrammatical Sentences HS born in the US } & Tokens \\
\hline \hline P-stranding & 11 \\
\hline Change in base-structure & 57 \\
\hline Pied-piping & 1 \\
\hline NO ANSWER & 4 \\
\hline In situ & 15 \\
\hline TOTAL TOKENS & 88 \\
\hline
\end{tabular}

Table 18. Ungrammatical Sentences - HS born in the US 


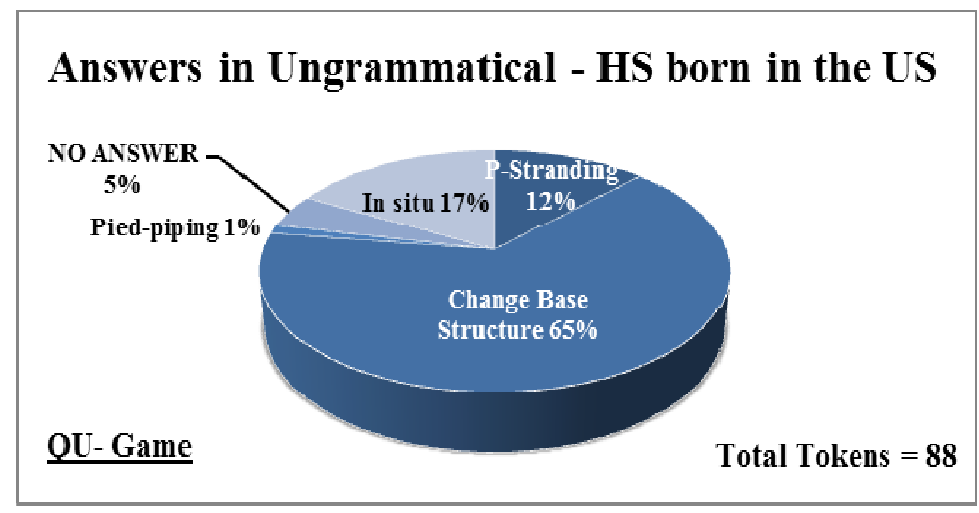

Figure 33. Ungrammatical Sentences - HS born in the US

\begin{tabular}{|l|c|}
\hline \multicolumn{1}{|c|}{ Ungrammatical Sentences - HS born in Brazil } & Tokens \\
\hline \hline P-stranding & 0 \\
\hline Change in base-structure & 22 \\
\hline Pied-piping & 2 \\
\hline NO ANSWER & 1 \\
\hline In situ & 3 \\
\hline \multicolumn{2}{|c|}{ TOTAL TOKENS } \\
\hline
\end{tabular}

Table 19. Ungrammatical Sentences - HS born in Brazil

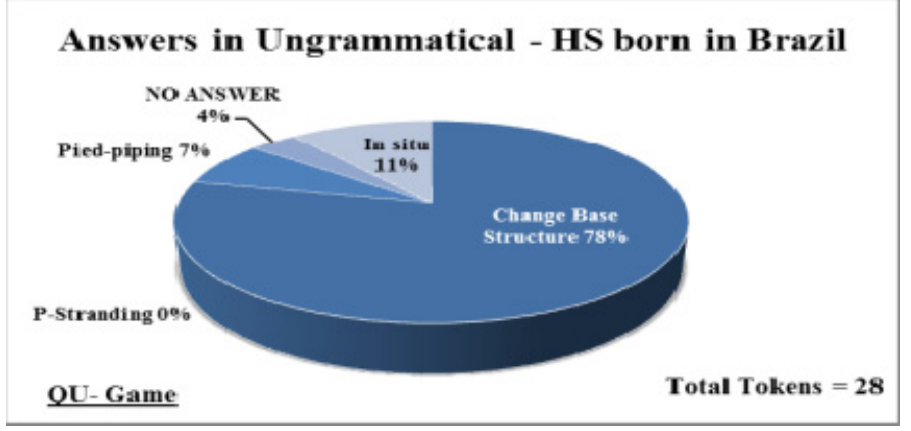

Figure 34. Ungrammatical Sentences - HS born in Brazil

\begin{tabular}{|l|l|}
\hline Ungrammatical Sentences - Monolinguals & Tokens \\
\hline \hline P-stranding & 0 \\
\hline Change in base-structure & 29 \\
\hline Pied-piping & 5 \\
\hline NO ANSWER & 1 \\
\hline In situ & 4 \\
\hline P-Ellipsis TOTAL TOKENS & 1 \\
\hline \multicolumn{2}{r}{$\mathbf{4 0}$} \\
\hline
\end{tabular}

Table 20. Ungrammatical Sentences - Monolinguals 


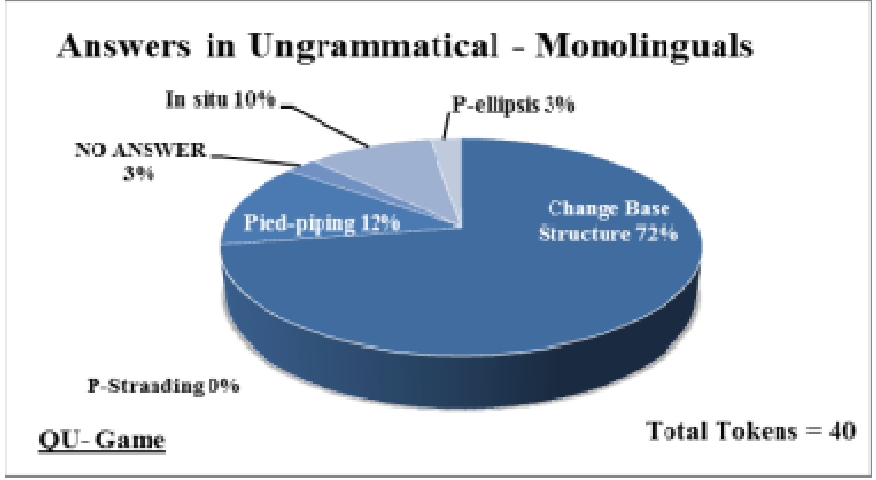

Figure 35. Ungrammatical Sentences - Monolinguals

\begin{tabular}{|l|c|}
\hline \multicolumn{1}{|c|}{ Ungrammatical Sentences - Caregivers } & Tokens \\
\hline \hline P-stranding & 0 \\
\hline Change in base-structure & 37 \\
\hline Pied-piping & 1 \\
\hline NO ANSWER & 0 \\
\hline In situ & 9 \\
\hline P-Ellipsis & 0 \\
\hline \multicolumn{2}{|c|}{ TOTAL TOKENS } \\
\hline
\end{tabular}

Table 21. Ungrammatical Sentences - Caregivers

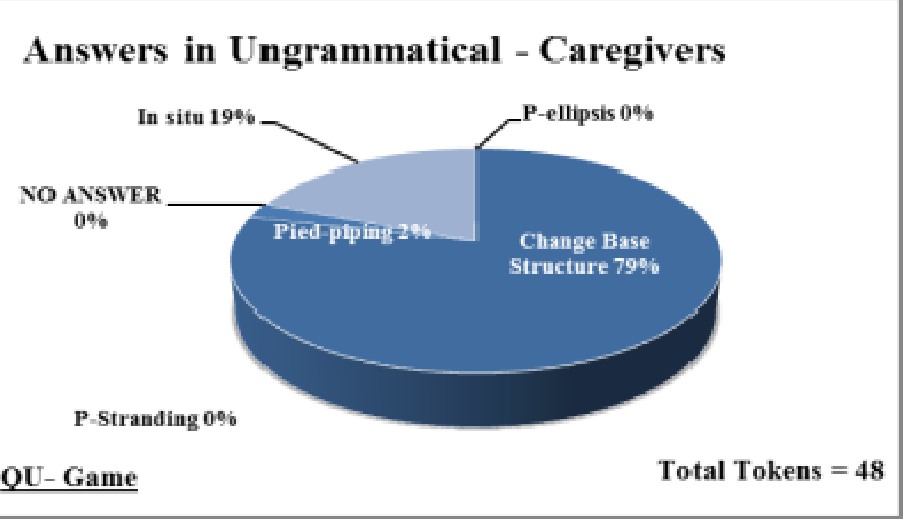

Figure 36. Ungrammatical Sentences - Caregivers

Table 22 below summarizes overall findings for ungrammatical sentences, which provide evidence that speakers' in all four groups process these sentences differently, in other words, their linguistic systems appear to compute that there is a constraint on PP movement in the base sentence under scrutiny. 


\begin{tabular}{|l|c|c|c|c|}
\hline \multicolumn{1}{|c|}{ 'QU- game': Ungrammatical } & HS born in the US & HS born in Brazil & Monolinguals & Caregivers \\
\hline \hline P-stranding & $12 \%$ & $0 \%$ & $0 \%$ & $0 \%$ \\
\hline P-ellipsis & $0 \%$ & $0 \%$ & $3 \%$ & $0 \%$ \\
\hline Change in Base Structure & $65 \%$ & $78 \%$ & $72 \%$ & $79 \%$ \\
\hline In situ & $17 \%$ & $11 \%$ & $10 \%$ & $19 \%$ \\
\hline NO ANSWER & $5 \%$ & $4 \%$ & $3 \%$ & $0 \%$ \\
\hline Pied-piping & $1 \%$ & $7 \%$ & $12 \%$ & $2 \%$ \\
\hline \multicolumn{2}{r|r|r|}{$100 \%$} & & $100 \%$ & $100 \%$ \\
\hline
\end{tabular}

Table 22. Ungrammatical Sentences - Overall

A one-way between groups ANOVA was conducted to assess whether or not the use of Change-in-Base-Structure varied across the four groups in ungrammatical sentences. There was no statistically significant difference at the $p<.05$ level in Change in Base Structure counts for the four groups: $\mathrm{F}(3,47)=.616, \mathrm{p}=.608$. Or, they are statistically similar, changing the base structure to avoid producing ill-formed interrogatives.

\subsection{Results 'Puppet Game’ Brazilian Portuguese}

Results from the 'Puppet Game' in BP do not converge with results from the 'QUgame' for the group of heritage speakers born in the US: while these speakers produced Pstranding at a rate of $42 \%$ and Pied-piping at a rate of $16 \%$ during the 'QU- game', they judged P-stranding as grammatically correct in only $22 \%$ of the tokens, judging Pied-piping as the correct answer $63 \%$ of the time, and judging both puppets right $12 \%$ of the time.

Figure 37, Figure 38, Figure 39, and Figure 40 summarize the 'Puppet Game' in BP:

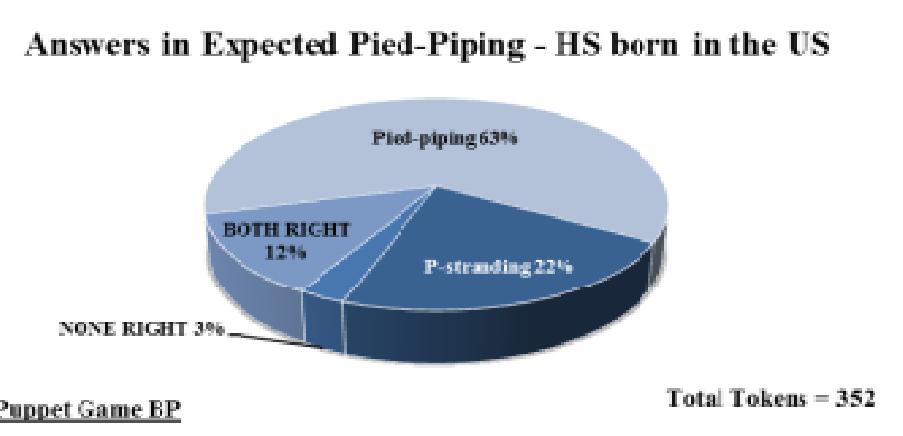

Figure 37. Answers in Expected Pied-Piping - HS born in the US 


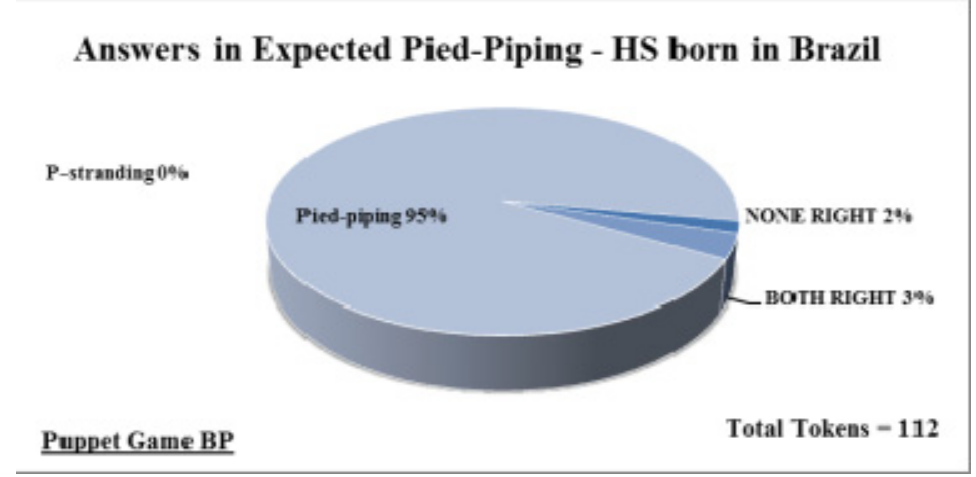

Figure 38. Answers in Expected Pied-Piping - HS born in Brazil

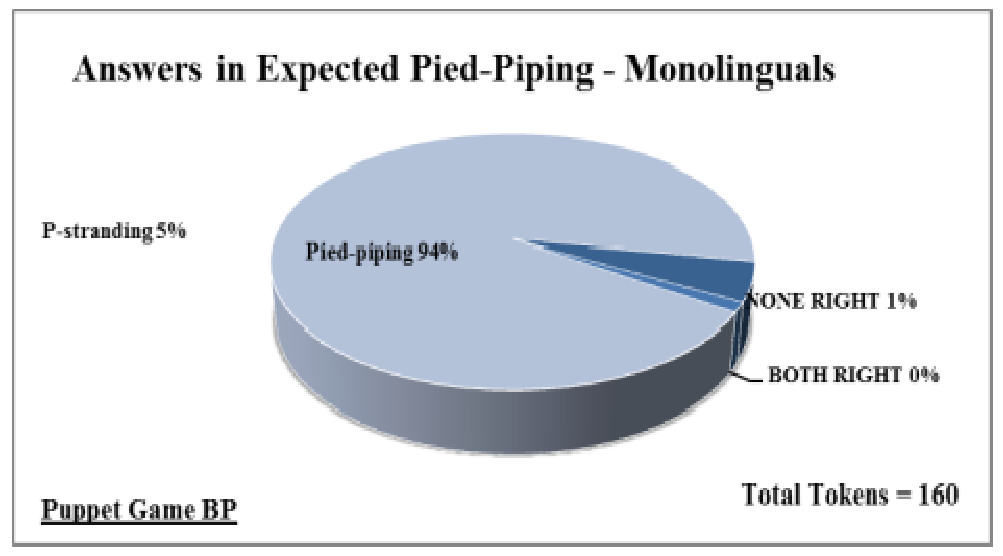

Figure 39. Answers in Expected Pied-Piping - Monolinguals

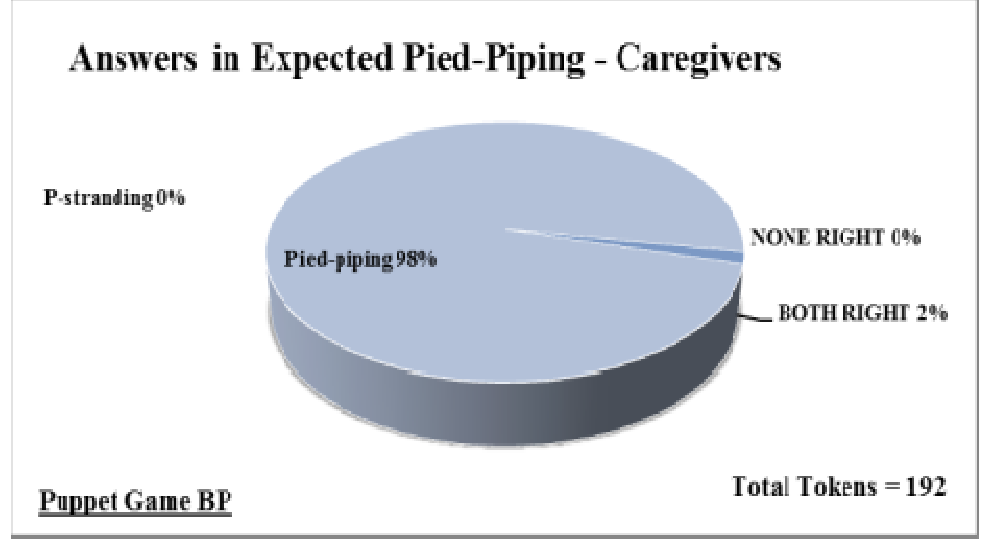

Figure 40. Answers in Expected Pied-Piping - Caregivers

Results from the remaining three groups show a clear preference for pied-piping, matching the results from the 'QU- game' for these groups. The increased percentage in the 
choice for pied-piping, when compared to the results of the 'QU- game', may be associated with the fact that in the 'Puppet Game' sentences containing P-ellipsis were not an available option.

Although results for the grammaticality judgment task differ numerically from the results seen in the 'QU- game', a one-way between groups ANOVA was conducted to assess whether the choice of P-stranding as being the grammatically correct option in the task varied across the four groups in sentences where PiP was the expected structure. There was a statistically significant difference at the $\mathrm{p}<.005$ level in P-stranding counts for the four groups: $\mathrm{F}(3,47)=8.214, \mathrm{p}<.001$. Post hoc comparisons using Tukey HSD test indicated that the mean count for the group of HS born in the US $(\mathrm{M}=3.55, \mathrm{SD}=3.13)$, was significantly different from the mean counts for the group of HS born in Brazil, $(\mathrm{M}=.00, \mathrm{SD}=.00)$, from that for the group of monolinguals, $(\mathrm{M}=.08, \mathrm{SD}=2.53)$, and from that for the group of adult caregivers $(\mathrm{M}=.00, \mathrm{SD}=.00)$. Post hoc comparisons also indicated that the latter three groups did not display statistically significant differences between each other in the choice of Pstranding as being the grammatically correct structure.

A one-way between groups ANOVA was also conducted to assess whether the choice of PiP as being the grammatically correct option in the task varied across the four groups in sentences where PiP was the expected structure. There was a statistically significant difference at the $\mathrm{p}<.005$ level in PiP counts for the four groups: $\mathrm{F}(3,47)=120.271, \mathrm{p}<.000$. Post hoc comparisons using Tukey HSD test indicated that the mean count for the group of HS born in the US $(\mathrm{M}=10, \mathrm{SD}=4.30)$, was significantly different from the mean counts for the group of HS born in Brazil, $(\mathrm{M}=15.14, \mathrm{SD}=1.07)$, from that for the group of monolinguals, $(\mathrm{M}=15, \mathrm{SD}=2.49)$, and from that for the group of adult caregivers $(\mathrm{M}=15.75$, $\mathrm{SD}=.62)$. Post hoc comparisons also indicated that the latter three groups did not display statistically significant differences between each other in the choice of PiP as being the grammatically correct structure. 
Figure 41, Figure 42, Figure 43, and Figure 44 show the results for ungrammatical sentences:

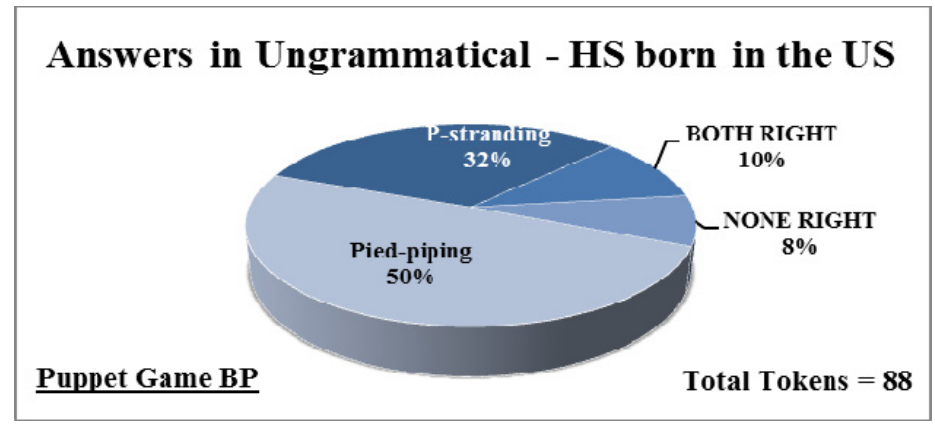

Figure 41. Answers in Ungrammatical - HS born in the US

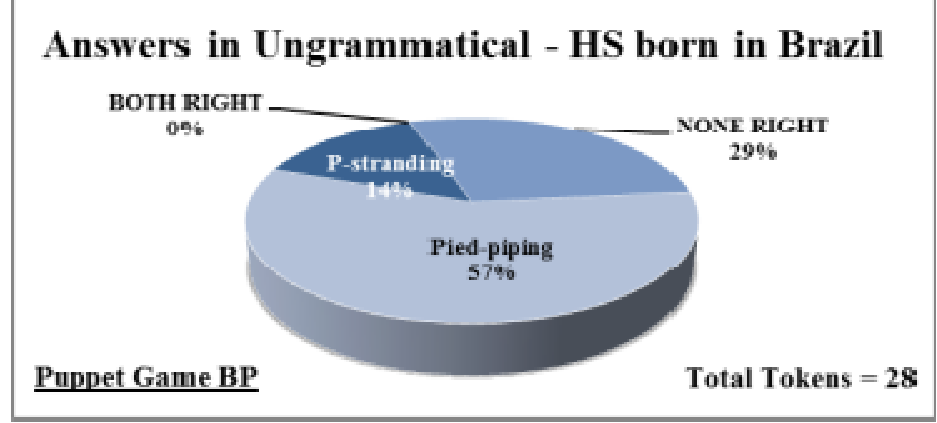

Figure 42. Answers in Ungrammatical - HS born in Brazil

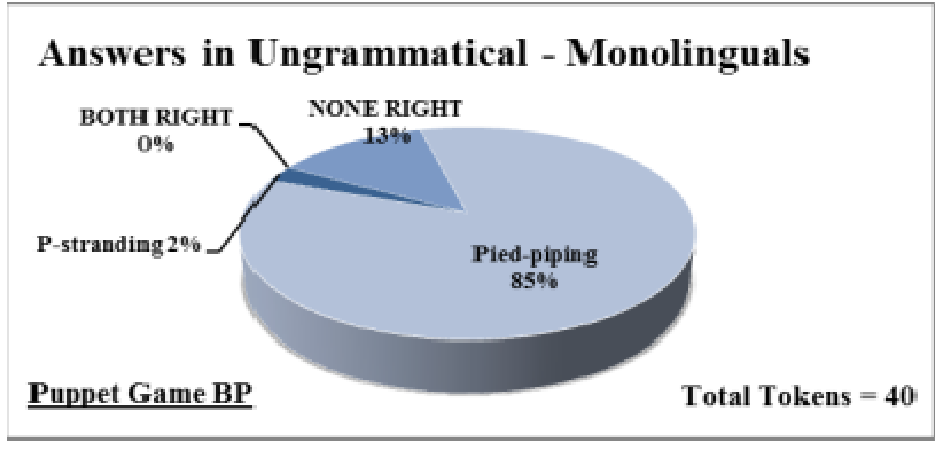

Figure 43. Answers in Ungrammatical - Monolinguals 


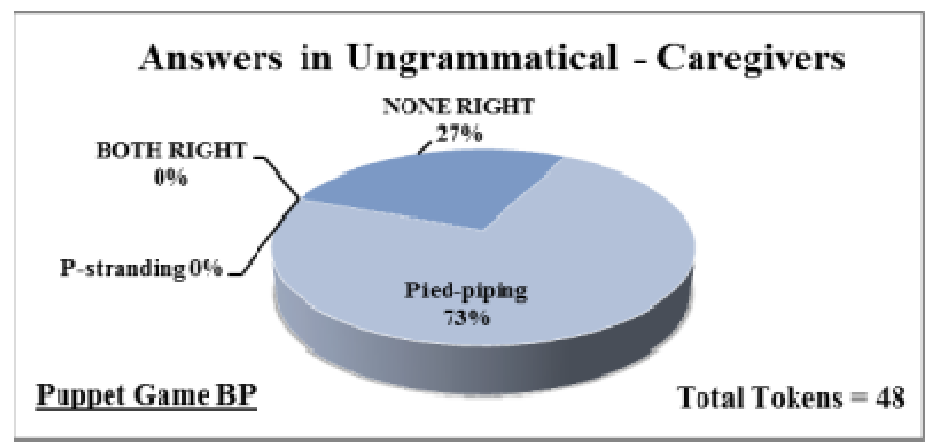

Figure 44. Answers in Ungrammatical - Caregivers

Results for the ungrammatical sentences converged for all four groups of participants, in two different ways: first, there was a preference for the same choice of structure participants had chosen in the grammatical sentences; second, from the perspective of qualitative observations made during the tasks, it appeared to be the case that participants in general would be reluctant to consider the possibility that both puppets could be wrong (nor the possibility that both puppets could be right, in the case of the filler sentences). It may be the case, therefore, that results from the 'Puppet Game' in BP do not accurately portray participants' grammars in regards to the sentences in which PP movement is proscribed in Brazilian Portuguese. It may also be the case that P-stranding in ill-formed (ungrammatical) sentences was more salient to participants than the semantic content (which was the culprit of the sentence malformation) of the sentence, and that therefore, speakers' decisions about grammaticality were influenced by what they deemed most salient in the sentence. The issue of which error is more salient to speakers might explain why even adult bilinguals performed relatively poorly on the game, judging both puppets wrong only in $27 \%$ of the tokens.

\subsection{Results 'WH- Game'}

Results from the 'WH- game' - for sentences in which P-stranding was the expected solution - corroborate overall descriptions for the usage of PP in WH- interrogatives in monolingual American English speakers: 0 occurrences of pied-piping were found in both 
groups of HS and P-stranding was used in $94 \%$ of the tokens for both groups. The remaining tokens were split between P-ellipsis (3\%), In situ (2\%), and change-in-base-structure (1\%) for the heritage speakers born in the US. Heritage speakers born in Brazil produced interrogatives using P-ellipsis in 6\% of the tokens. Results are summarized in Figure 45 and in Figure 46 below:

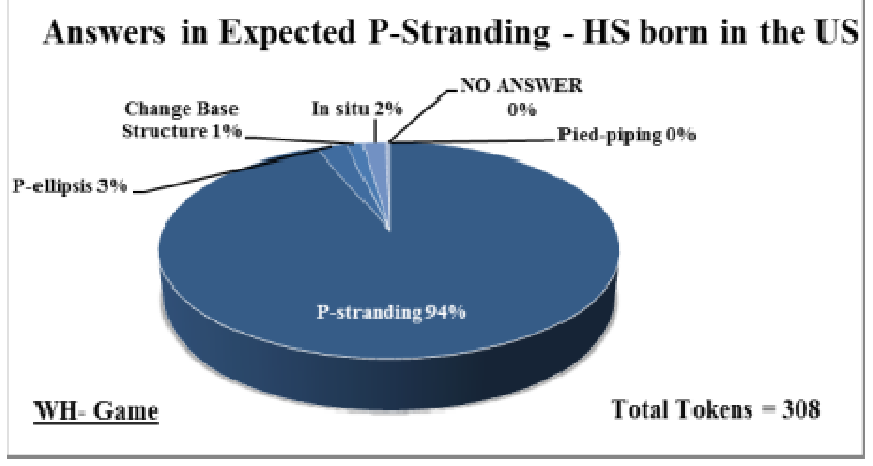

Figure 45. Answers in Expected P-stranding - HS born in the US

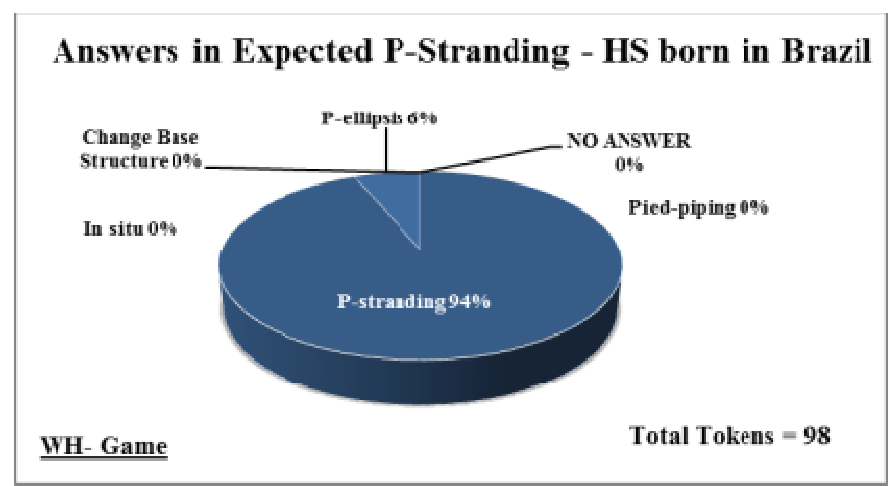

Figure 46. Answers in Expected P-stranding - HS born in Brazil

A one-way between groups ANOVA was conducted to assess whether the use of Pstranding varied across the two groups in sentences where P-stranding was the preferred structure. No statistically significant difference between the two groups was found. In regards to the sentences in which PP movement would create ungrammatical WHinterrogatives, both groups of heritage speakers displayed preference for the change in base structure solution, as shown in Figure 47 and Figure 48. The preference for a different base- 
structure provides evidence of awareness of the fact that the movement of the prepositional phrase in these sentences creates ungrammatical interrogatives as an outcome.

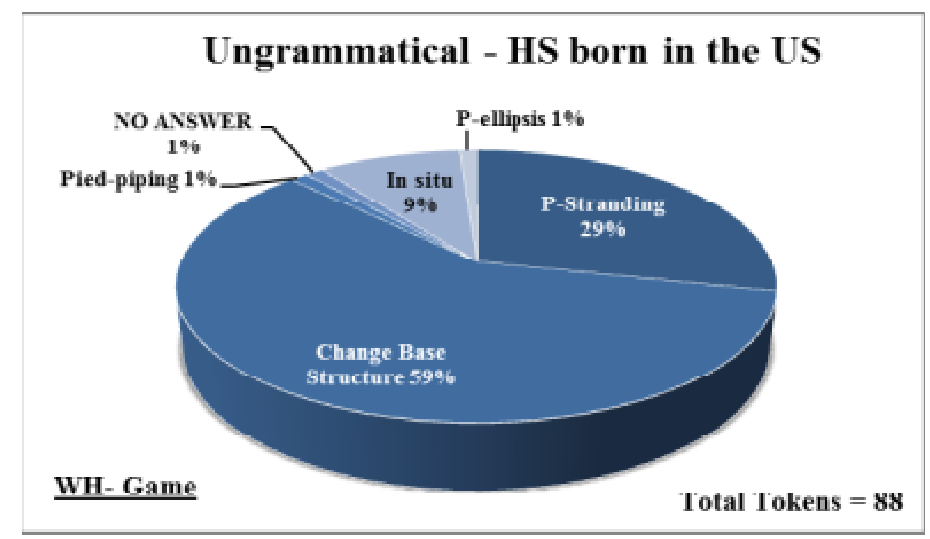

Figure 47. Answers in Ungrammatical - HS born in the US

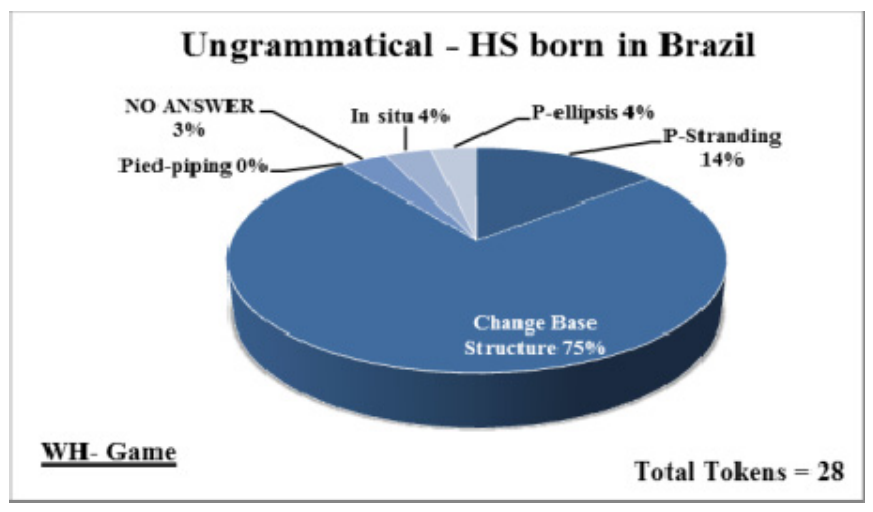

Figure 48. Answers in Ungrammatical - HS born in Brazil

A one-way between groups ANOVA was conducted to assess whether the use of Change-in-Base-Structure varied across the two groups in sentences in which movement would produce ungrammatical outcomes. No statistically significant difference between the two groups was found.

\subsection{Results 'Puppet Game’ American English}

Both groups of heritage speakers, born in the US and born in Brazil, displayed a preference for P-stranding in the 'Puppet Game' in AE, as per in Figure 49 and Figure 50: 


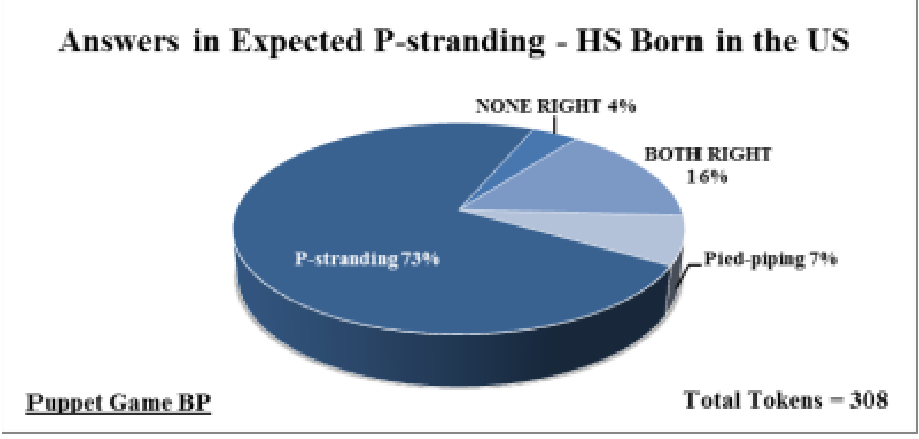

Figure 49. Answers in Expected P-stranding - HS born in the US

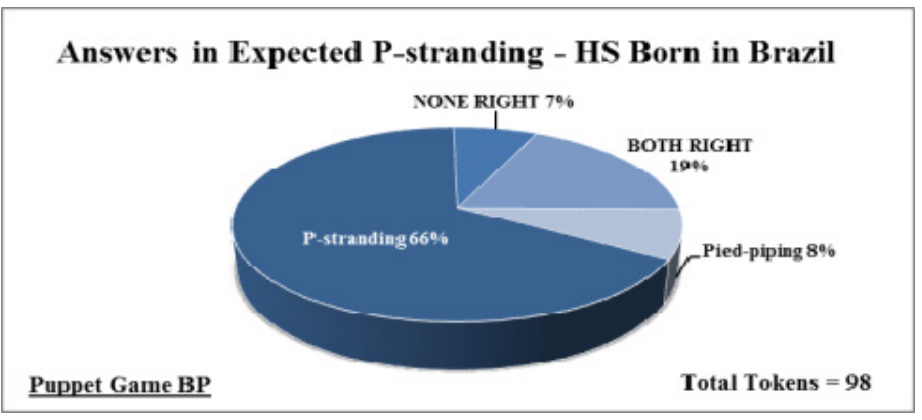

Figure 50. Answers in Expected P-stranding - HS born in Brazil

Most of the tokens in which PiP was judged the grammatical option consisted of sentences containing the prepositions in and on. One hundred percent (100\%, 12 out of 12), of the tokens in which both options were deemed ungrammatical came from P14, a 7 year-old male, who, giving clear signs of fatigue, produced the same answer during most of this grammaticality judgment task in American English.

A one-way between groups ANOVA was conducted to assess whether the choice of P-stranding as being the grammatically correct option varied across the two groups, in sentences where this was the preferred structure. No statistically significant difference between the two groups was found.

The results for the ungrammatical sentences in this game are shown below: 


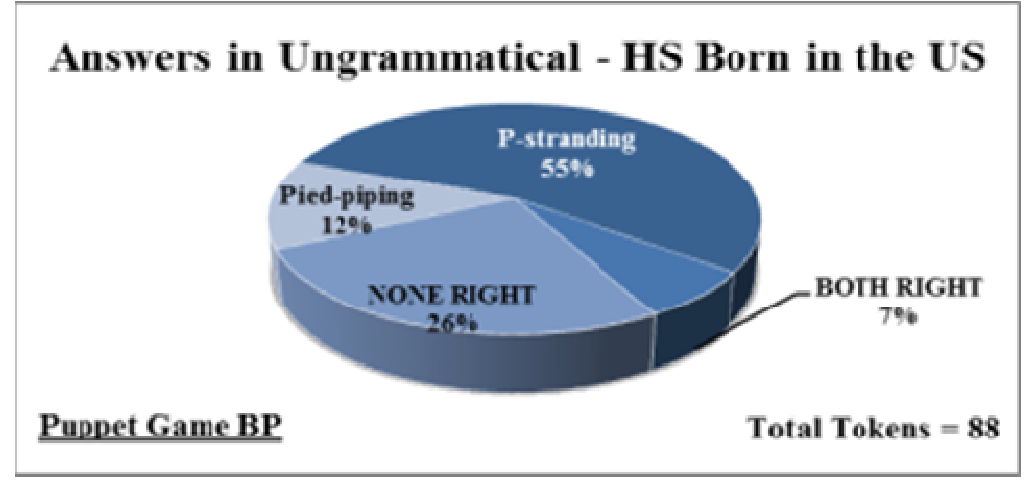

Figure 51. Answers in ungrammatical - HS born in the US

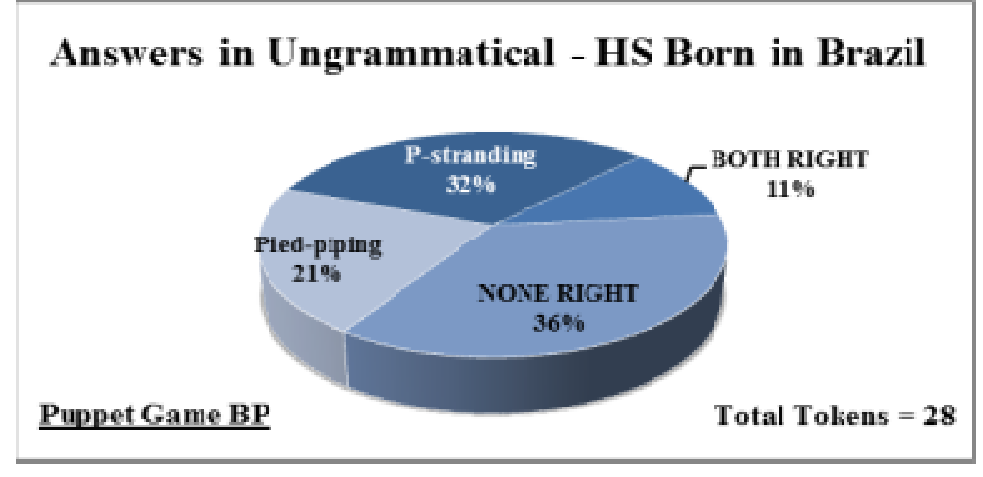

Figure 52. Answers in ungrammatical - HS born in Brazil

Following the trend seen in the grammaticality judgment task in Brazilian Portuguese, heritage speakers in both groups seemed reluctant to opt for both puppets being wrong (or for both being right, for that matter), although there was an increase in the percentage of NONE RIGHT answers in both groups when compared with the same task in Brazilian Portuguese. The increase in the percentage of the NONE RIGHT choice was sharper in the group of heritage speakers of BP born in the US (from $8 \%$ to $26 \%$ for NONE RIGHT) than in the group of heritage speakers born in Brazil (from 29\% to 36\%).

A one-way between groups ANOVA was conducted to assess whether the use of Change-in-Base-Structure varied between the two groups in sentences where movement would produce ungrammatical outcomes. No statistically significant difference between the two groups was found. 


\section{CONCLUSION}

Overall results show that the group of HS born in the US differs statistically from the group of HS born in Brazil in regards to their heritage language, Brazilian Portuguese.

Heritage speakers of BP born in the US also differ statistically from the other two groups, young monolingual speakers of BP and adult caregivers (late bilinguals). Moreover, results from the experiment in English confirm that both groups of HS (born in the US, and in Brazil) are statistically similar in what concerns their L2 (dominant language), displaying roughly the same behavior (vis-à-vis the use of P-stranding) described in the literature for their monolingual American English counterparts.

Results also indicate HS of BP resort to P-stranding productively, countering assumptions of the theory of Markedness, as put forth by Faingold (Faingold, 2003), according to which children would omit or replace the more-marked form with its lessmarked counterpart. Probably the most interesting implication that can be derived from this observation is in respect to how the decision about which elements are marked and which elements are unmarked is made: in the case of PP movement, the more marked value - Pstranding - was chosen on the basis of attested crosslinguistic frequency. However, from the perspective of computational cost, $\mathrm{P}$-stranding moves less components, being a "more economic" solution. The same theory of Markedness (Faingold, 2003), recognizes that language change also happens triggered by external factors, such as borrowing, or level of social prestige of the linguistic feature in question. It is hence a logical possibility that the sparse occurrence of P-stranding in languages may be because of diachronic variations resulting not from internal, but from external factors. Therefore, in order to delineate a theory of Markedness for language acquisition, other factors besides crosslinguistic frequency should be considered when defining which feature values are marked, and which are unmarked. Results present evidence contra the Interface Hypothesis (Tsimpli, Sorace, Heycock and Filiaci, 2004: 258), according to which uninterpretable features of L1 and L2 are acquired unproblematically, and are not subject to either attrition or transfer. 
Results discussed in chapter 5.3 provide evidence which supports hypothesis $1-$ which predicted that heritage speakers of Brazilian Portuguese do use P-stranding in interrogative sentences, when speaking Brazilian Portuguese (discussed in chapter 3). Moreover, results show that P-stranding is not used by participants in the other three groups, which resort to the target structure (expected in BP), of pied-piping the preposition along with its complement - total P-stranding equaling 1 in 112 tokens for the group of heritage speakers born in Brazil, 0 in 160 tokens for the group of monolinguals, and 1 in 192 tokens for the group of adult bilinguals/caregivers.

In light of the discussion in chapters 5.3 and 5.4, no signs of attrition, in regards to PP movement in QU- interrogatives, were detected in the group of heritage speakers born in Brazil or in the group of adult bilinguals. The lack of evidence of attrition does not mean that there are no ongoing changes in the BP spoken in South Florida, and it does not preclude the possibility that P-stranding will get incorporated into the variety of BP spoken in South Florida in generations to come. It is also worth mentioning that signs of attrition have been observed in many other aspects of the Brazilian Portuguese spoken in South Florida, especially in the lexicon and in morphosyntactic structures, for both heritage speakers born in Brazil and bilingual adults. Some changes are detected within the first few months of arrival to the United States.

As for protracted acquisition, the discussion presented in chapter 5.3, along with data in Table 11 and Table 16, suggest that acquisition of target movement process in QUinterrogatives in heritage speakers' BP is linked to meaningful increase in linguistic input for extended periods of time, and will not happen otherwise.

In regards to hypothesis 2 - which predicted that heritage speakers of Brazilian Portuguese use preposition stranding systematically - evidence presented in chapter 5 shows that heritage speakers of BP born in the US use P-stranding systematically, doing so with verbs that select prepositional complements in Portuguese but not in English, and also 
resorting to a change in the base structure of the original sentence in order to form an interrogative when movement of any type is proscribed.

Hypothesis 3 predicted that when heritage speakers do not resort to the use of Pstranding they use P-ellipsis, and that pied-piping would come among the least preferred solutions. Again, evidence discussed in chapter 5 supports this hypothesis, with the restriction that the hypothesis predicted that in situ QU- interrogatives would be more frequent than pied-piping, but the opposite was shown to be true.

In hypothesis 4 , the possibility that findings from the elicitation task would not converge with findings from the grammaticality judgment task was brought forward. Evidence discussed in chapters 5.3 and 5.4 supports hypothesis 4. Additionally, results from the two tasks converged for the remaining three groups of participants.

\subsection{A Word on Experimental Design and Natural Speech}

Although the results already discussed bring forward fairly compelling evidence against the notions of (early) attrition and of protracted acquisition of PiP in Brazilian Portuguese for both heritage speakers' groups - born in the US and born in Brazil - it is my perception that some points evinced in the epistemic reflection made in chapter 3.1 still hold, and that participants such as P8, for example, were subject to early attrition. It is also a vivid memory that P16, whom I have known since age 1, used to produce P-stranding in her Brazilian Portuguese, a fact confirmed by her mother, also a participant in the experiment, Pad51, who, when asked about this, replied "Yes, she used to this, but now she doesn't (do it) anymore."

Furthermore, just as I write these last lines, I received a call from participant PAd52, mother of P12 - who belongs to the group of HS born in Brazil, and whose LOR $=3$ years telling me the following: "Do you know that way of asking questions you told me about? Well, my daughter, P12, just started doing this, and I thought I should let you know." 
It follows that the ideal design for an investigation on heritage language acquisition would be one that combines experimental design with data collected from natural speech.

\subsection{Pedagogical Implications}

In spite of the previous discussion, it remains the fact that the data presented in chapter 5, along with the overall discussion of the findings, show that HS of BP born in Brazil, or, the heritage bilinguals who were exposed to richer linguistic inputs for an extended period of time in both languages, did slightly better in producing target-like structures for all instances in both languages, surpassing even the results of late bilingual adults (caregivers) in their native language, Brazilian Portuguese.

In addition, the analyses point out to increased linguistic input during an extended period of time as being the culprit for the more target-like behavior of participants P16, P18, and P28 in their Brazilian Portuguese.

The findings described above, combined, provide compelling evidence in favor of recommending parents of heritage speakers to increase linguistic input given to heritage speakers in Brazilian Portuguese, and not the opposite, as it is recommend by local school systems.

As a matter of fact, since there is little possibility that most members of the Brazilian immigrant community would be able to provide increased linguistic input (i.e., trips to Brazil), to their children for extended periods of time (for financial reasons), reading activities may prove to be an affordable and readily available alternative, since there is evidence in the literature (i.e., Volpato, Verin \& Cardinaletti, in press, also Jusczyk \& Hohne, 1997, and in Verin 2010, both qtd. in Volpato, Verin \& Cardinaletti, in press) supporting the assumption that early exposure to reading, for extended periods of time, facilitates the acquisition of both lexical items and of syntactic structures usually found in more formal registers of the language or in written language. 


\subsection{Epistemic Reflection 2.0}

On the basis of the first reflection, chapter 3.1, and derived from qualitative observations and from the data collected during this investigation, if a rough sketch of heritage speakers and the acquisition of their heritage language were to be made, rather than referring to an incomplete process of acquisition, the sketch would be as follows: the linguistic input received by heritage speakers of Brazilian Portuguese in South Florida seems to be target-like in regards to PP movement in QU- interrogatives - a fact corroborated by the evidence collected from the control group of caregivers. Therefore, the matter doesn't seem to be one of quality in the linguistic input (i.e., heritage speakers are receiving non-target like input in Brazilian Portuguese), but rather one of quantity: heritage speakers of Brazilian Portuguese, in the absence of sufficient quantity of linguistic input in the heritage language, and exposed to two distinct linguistic systems - and subject to fewer sociolinguistic constraints - resort to internal mechanisms in order to decide about the grammaticality of structures. It is likely that these internal mechanisms are driven by factors such as computational cost (economy) and search for systematicity.

Additional empirical evidence would come from observing how these speakers use object pronouns (when used with indirect objects) in English and in Portuguese: in English (me, you, him/her, us, them), the use is target-like. In Portuguese, though, where most of the object pronouns do not differ overtly from personal pronouns (eu-mim, você-você, ele-ele/elaela, nós-nós,vocês-vocês, eles-eles/elas-elas), except for the first person singular (eu-mim), heritage speakers use 'eu', not ' $\mathrm{mim}$ ' (although in English personal and object pronouns do differ in the first singular: I-me). In other words, it seems that they are not transferring from English, but they are not producing target-like structures in Portuguese either. Moreover, this use extends to the Comitative case in Portuguese: HS of BP use 'com eu', instead of the target "comigo".

\footnotetext{
${ }^{4}$ Literally: "with me"

5 "with me" in the Comitative case in Portuguese
} 


\section{LIMITATIONS AND FUTURE RESEARCH}

Perhaps the main limitation of the present study is that only the production and grammaticality-judgment of WH-/QU- interrogative structures were assessed and analyzed. The executive decision was taken early during the design phase of the experiment, as it was deemed important to the scope of the study that participants undertake both and elicited production task and a grammaticality-judgment task. At that time, creating an experiment to elicit PPs in relative clauses required time that was not available.

Nevertheless, it is our perception that these heritage speakers resort to P-stranding in relative clauses, even more so than in QU-/WH- interrogatives, making these clauses an enticing subject for further investigation.

Another limitation of this study is that, as a result of time constraints, it was not possible to pair the cross-sectional study with a longitudinal investigation. A couple of longitudinal studies would be of great importance to further determine claims of early attrition observed by parents (described in section 1 of this paper): ideal participants would be heritage speakers whose both parents are Brazilian, between ages 5 and 6, a point in time when L1 acquisition - Portuguese - of preposition and prepositional phrases is well underway, but schooling in L2 - English - is still at its inception, minimizing linguistic input in L2. It would be ideal to follow these speakers during kindergarten and first grade.

Still as a consequence of time constraints, there was no opportunity to analyze the data on P-ellipsis more carefully, and attentively. Such analysis is a must for future studies, though, since all four groups of participants, which had diverged in many issues, converged in the production of P-ellipsis.

A second longitudinal study would include the older heritage speakers who took part in the present investigation to control for protracted acquisition in the absence of increased linguistic input. 
Further research is needed in order to determine whether P-ellipsis is linked to suppletive forms of prepositions plus demonstrative pronouns, or to the QU- words "que" (what) and "qual" (which).

Although great effort was put in trying to mimic, as much as possible, a naturalistic speech environment during the interviews by turning tasks into games, observations of heritage speakers made in-class and in naturalistic environments still point to the direction that natural speech will somewhat differ from any speech recorded in laboratory environments. It follows that an important addition to the present investigation would be recordings of natural speech in which instances of QU- interrogatives and of relative clauses could be singled-out.

As evinced in chapter 6, although the margin is slim, it appears to be the case that HS of BP born in Brazil, who were exposed to richer linguistic inputs for an extended period of time in both languages, did slightly better in producing target-like structures for all instances of both tasks in both languages. More studies aimed at further determining the effects of increased linguistic input in heritage speakers' L1 would constitute an enticing task.

Future studies should investigate whether the discrepancies found between the results from the elicitation task and the results from the grammaticality judgment task can be attributed to optionality. If optionality is at play, more detailed analyses should look into possible triggers for the phenomenon, and should look for a mathematical model for optionality.

Lastly, in the interest of producing empirical evidence with the potential of having pedagogical implications, and which may have the potential to improve the lives of people in communities of immigrants, it would highly desirable to conduct studies in the likes of the one conducted by Volpato, Verin \& Cardinaletti (in press), in which reading strategies were used to facilitate the acquisition of passive forms (no longer highly productive in Italian), during a 8-month period of time. 


\section{BIBLIOGRAPHY}

Baetens Beardsmore, Hugo. Bilingualism : Basic Principles. eBook Collection (EBSCOhost): College-Hill Press, 1986. Web. 2 February 2012.

$<$ http://web.ebscohost.com.ezproxy.fiu.edu/ehost/ebookviewer/ebook/nlebk_23392_ AN?sid=d28a97c5-8ac3-446b-9cb1-d69e1152cbb8@sessionmgr110\&vid=1>.

Baltin, Mark and Paul M. Postal. "More on reanalysis hypothesis." Linguistic Inquiry 27 (1996): 127-145.

Boskovic, Zelijko and Howard Lasnik, Minimalist Syntax: the Essential Readings. Blackwell Publiching, 2007. print.

Bourdieu, Pierre. Language and Symbolic Power. Ed. John B. Thompson. Harvard University Press, 1991.

Cabana, Laís T. H. and Paula F. E. Cardoso. "CONSTRUÇÕES COM SE APASSIVADOR E SE INDETERMINADOR: GRAMÁTICA TRADICIONAL X LINGUAGEM FALADA." Universidade Federal de Pelotas UFPel, n.d. online. 20 April 2012. $<$ http://www.ufpel.edu.br/cic/2009/cd/pdf/LA/LA_00508.pdf $>$.

Carranza, Luz Marina Vásquez. "Cross-linguistic influence in the syntactic domain in simultaneous language acquisition: evidence from extraction constructions involving the object of a preposition in the speech of an English-Spanish bilingual child." Káñina 33.1 (January-June 2009): p85. Word Count: 9301. WEB. $<$ http://go.galegroup.com.ezproxy.fiu.edu/ps/i.do?id=GALE\%7CA210441496\&v=2.1 $\& u=$ flstuniv $\& i t=r \& p=I F M E \& s w=w>$.

Cegalla, Domingos Paschoal. Novíssima Gramática da Língua Portuguesa. 48th . São Paulo: Companhia Editora Nacional, 2008. Print.

Chomsky, Noam. The minimalist program. Cambridge, Mass.: The MIT Press, c1995. print.

Chosmky, Noam. Lectures on Government and Binding. Cinnaminson, NJ: Dordrecht, Holland, 1981. print.

—. Lectures on Government and Binding: the Pisa Lectures. 7th. Berlin; New York: Mouton de Gruyter, 1993.

de Oliveira, Mariana Fagundes. "A voz passiva no português do século XX." INVENTÁRIO Revista dos Estudantes da Pós-Graduação em Letras da Universidade Federal da Bahia 2005, 3 ed.

de Souza, Cláudia R. Relativa Cortadora: Movimento ou Apagamento? Thesis. Porto Alegre, BR: UFRGS, 2007. online.

Depiante, Marcela and Thompson, Ellen. "Preposition Stranding and Ellipsis in Heritage Speakers of Spanish." Bilingual Workshop in Theoretical Linguistics 14. Toronto: University of Toronto, 9 December 2010.

Edwards, John V. "Foundations of Bilingualism." Bhatia, Tej K. and William C. Ritchie. Handbook Of Bilingualism. eBook Collection (EBSCOhost): Blackwell, 2004. 7-31. Web. 2 February 21012. 
$<$ http://web.ebscohost.com.ezproxy.fiu.edu/ehost/detail?sid=80c80a8c-fdb1-4670b28b-39aed8c3bbe3@sessionmgr111\&vid=1\#db=nlebk\&AN=108765>.

Everaert, Martin, and Henk C. Riemsdijk. The Blackwell Companion to Syntax. Malden, MA, USA: Blackwell Pub, 2006. Print.

Faingold, Eduardo D. The Development of Grammar in Spanish and the Romance Languages. Basingstoke: Palgrave Macmillan, 2003. Internet resource.

Feigenbaum, Susanne and Dennis Kurzon. Prepositions in Their Syntactic, Semantic, and Pragmatic Context. Amsterdam: J. Benjamins Pub, 2002. Print.

Ferreira-Sell, Fabíola S. "A Aquisição das Interrogativas WH in situ em Português Brasileiro." Working Papers in Linguística UFSC 6 (2002): 55-76. online.

Gass, Susan M and Alison Mackey. Data Elicitation for Second and Foreign Language Research. Mahwah, N.J: Lawrence Erlbaum Associates, 2007. Print.

Girju, Roxana. "The Syntax and Semantics of Prepositions in the Task of Automatic Interpretation of Nominal Phrases and Compounds: A Cross-Linguistic Study." Computational Linguistics 35.2 (2009): 185-228. electronic.

Grégis, Rosi Ana. Aquisição de Preposições Desacompanhadas, por aprendizes de inglês, falantes de Português Brasileiro. scientific. Universidade Feevale. VITÓRIA-ES: , 18 A 21 DE OUTUBRO DE 2011.

Grolla, Elaine. "Sobre a aquisição tardia de QU in situ em Português Brasileiro." DELTA: Documentação de Estudos em Linguística Teórica e Aplicada 21.1 (2005): 57-73. online. 27 March 2012.

$<$ http://www.scielo.br/scielo.php?script=sci_arttext\&pid=S010244502005000100003>.

—. "Sobre a Aquisição Tardia de QU in situ em Português Brasileiro." D.E.L.T.A. 21.1 (2005): 57-73. online.

Grosjean, François. "Studying Bilinguals: Methodological and Conceptual Issues." Bhatia, Tej K. and William C. Ritchie. Handbook Of Bilingualism. eBook Collection (EBSCOhost): Blackwell Pub, 2004. Web.

Han, Zhaohong, and Terence Odlin. Studies Of Fossilization In Second Language Acquisition. Ipswitch: Multilingual Matters, 2006. eBook Collection (EBSCOhost). 18 April 2012. $<$ http://web.ebscohost.com/ehost/detail?sid=c04d238c-dc33-495d-b57a104518941e63\%40sessionmgr14\&vid=1\&hid=13\&bdata=JnNpdGU9ZWhvc3QtbGl 2ZQ\%3d\%3d\#db=nlebk\&AN=141139>.

Hoff, Erika. Language Development. Fourth Edition. Belmont: WADSWORTH CENGAGE Learning, 2009. Print.

Hornstein, Norbert and Weinberg, Amy. "Case Theory and Prepostion Stranding." Linguistic Inquiry 12.1 (Winter, 1981): 55-91. Web. <http://www.jstor.org/stable/4178205>.

Hume, Elizabeth. "Markedness." Oostendorp, M. Van, et al. Companion to Phonology. Blackwell, 2011. 79-106. electronic. $<$ http://www.ling.ohiostate.edu// ehume/papers/Companion_markedness(proofs)2011.pdf>. 
Inoue, Kyoko. "Japanese: a Story of Language and People." Shopen, Timothy. Languages and their Speakers. Philadelphia: University of Pensylvannia Press, 1987. 241-299. Reprint.

Iverson, M. "Knowledge of Noun-Drop across Various Lexical and Functional Categories in Heritage Spanish Bilinguals." MS. 2010.

Klein, Elaine C. "(Mis)construing null prepositions in L2 intergrammars: a commentary and proposal." Second Language Research 17.1 (2001): 37-70. online.

Law, Paul. "Preposition stranding." The Blackwell Companion to Syntax. Ed. Martin Everaert and Henk van Riemsdijk. Oxford: Blackwell, 2006. 631-684.

Lech, Dana McDaniel and Dorota. "The Production System's Formulation of Relative Clause Structures: Evidence from Polish." Language Acquisition Vol. 11 .No. 2 (2003): pp. 63-97. Web. <http://www.jstor.org/stable/20011549>.

Li, Ping, Sara Sepanski and Xiaowei Zhao. "Language History Questionnaire: a Web-based Interface for Bilingual Research." Behavior Research Methods 38.2 (2006): 202-210. January 2012.

Lippi-Green, Rosina. English with an accent: Language, ideology, and discrimination in the United States. London \& New York: Routledge, 1997.

McDaniel, Dana, Cecile McKee, and Helen S. Cairns. Methods for Assessing Children's Syntax. Cambridge, Mass: MIT Press, 1996. Print.

Montrul, S. and M. Polinsky. "Why not Heritage Speakers?" Linguistic Approaches to Bilingualism 1.1 (2011): 58-62. print.

Müller, Natascha and Aafke Hulk. "Bilingual first language acquisition at the interface between syntax and pragmatics." Bilingualism: Language and Cognition 3 (2000): 227-244. electronic.

Oliveira, Marcia Santos Duarte de. Análise Sintática do Português Falado no Brasil. Vol. 2. Rio de Janeiro: Multifoco, 2010. 2 vols. print.

—. Análise Sintática do Português Falado no Brasil. Vol. 1. Rio de Janeiro: Multifoco, 2010. 2 vols. print.

Radford, A. Syntactic Theory and the Structure of English: A Minimalist Approach. Cambridge: Cambridge University Press, 1997. Print.

Radford, Andrew. Minimalist syntax: exploring the structure of English. Cambridge: Cambridge University Press, 2004.

Riemsdijk, Henk C. van. A Case Study in Syntactic Markedness: The Binding Nature of Prepositional Phrases. Lisse: Peter de Ridder Press, 1978. Print.

Rodriguez-Mondonedo, Miguel, William Snyder and Koji Sugisaki. "Clitic-climbing in Child Spanish and the Theory of Parameters." Online Proceedings Supplement of the 29th BostonUniversity Conference on Language Development. 2005. online.

$<$ http://faculty.human.mie-u.ac.jp/ sugisaki/>. 
Rothman, Jason. "Understanding the Nature and Outcomes of Early Bilingualism: Romance Languages as Heritage Languages." International Journal of Bilingualism June 2009: 155-163. electronic.

Salles, H.M-L. "Preposition pied-piping and preposition stranding: a minimalist approach." Research Papers in Linguistics 6 (1995): 97-123.

Salles, Heloísa M.M. Lima. "Aspectos da Sintaxe de Clíticos e Artigos em Português." Revista Letras 56 (2001): 141-155.

Serratrice, Ludovica, Antonella Sorace and Sadra Paoli. "Crosslinguistic influence at the syntax-pragmatics interface: Subjects and objects in English-Italian bilingual and monolingual acquisition." Bilingualism: Language and Cognition 7 (2004): 183-20. electronic.

Smith, Neil. Chomsky: Ideas and Ideals. Combridge University Press, 2002. electronic.

Sorace, A. "Pinning Down the Concept of Interface in Bilingualism." Linguistic Approaches to Bilingualism 1.1 (2011): 1-33. print.

Sorace, A. "Syntactic Optionality at Interfaces." Cornips, Leonie (ed. and introd.) and Karen P. (ed. and introd.) Corrigan. Syntax and Variation: Reconciling the Biological and the Social. Amsterdam: John Benjamins, 2005. 46-11. print.

Stowell, Timothy. "Conditions on reanalysis." MIT Working Papers in Linguistics 4 (1982): 245-269. online.

Sugisaki, Koji and William Snyder. "Do Parameters Have Default Values? Evidence from the Acquisition of English and Spanish." Proceedings of the Fourth Tokyo Conference on Psycholinguistics. Ed. Yukio Otsu. Tokyo: Hituzi Syobo, 2003. 215-237. online. 15 March 2012. <http://faculty.human.mie-u.ac.jp/ sugisaki/>.

—. "Preposition Stranding and the Compounding Parameter: A Developmental Perspective. ." Proceedings of the 26th annual Boston University Conference on Language Development. Ed. Anna H.-J. Do, Laura Dominguez and Aimee Johansen. Somerville, Massachusetts: Cascadilla Press., .2002. 677-688. online. $<$ http://faculty.human.mie-u.ac.jp/ sugisaki/>.

—. "The parameter of preposition stranding: A view from child English." Language Acquisition 13 (2005/2006): 349-361.

Sugisaki, Koji. "The Acquisition of Preposition Stranding and its Theoretical Implications." 2008. MIE University Japan. 02 March 2012. <faculty.human.mieu.ac.jp/ sugisaki/Sugisaki_08c.pdf>.

Tsimpli, I.M., Sorace, A., Heycock, C. and Filiaci, F. "First Language Attrition and Syntactic Subjects: A Study of Greek and Italian Near-Native Speakers of English." International Journal of Bilingualism 2004: 257-277.

Valdés, G. "Heritage Language Students: profiles and possibilities." Peyton, Joy K, Donald A. Ranard and Scott McGinnis. Heritage Languages in America: Preserving a National Resource. McHenry, IL: Center for Applied Linguistics, 2001. 7-77. Print.

Volpato. "The Acquisition of Passives in Italian:." n.d. 
APPENDICES 
Appendix 1 - The 'QU- game': Target \& Filler Sentences 
The questions below are ordered by target-construction, but the participant was heard sentences which were scrambled by a computer-generated randomization algorithm, from RANDOM.ORG (http://www.random.org/). See http://www.random.org/randomness/ for a detailed discussion of pseudo-random and true random numbers.

(1) A Mônica gosta daquele livro. Monica likes (3rd. S. Pres.) of + that (M.) book.

TARGET BP: De qual livro a Maria gosta?

EXPECTED TARGET HS of BP:*Qual livro que a Maria gosta de? POSSIBLE ANSWER: Do livro do Harry Potter.

(2) O Cascão

D. A. M. Cascão likes ( $3^{\text {rd }}$. S. Pres. $) \quad$ of....

TARGET BP: $\quad$ De que (que) o João gosta?

OR P-deletion _ _ Que (que) o João gosta?

EXPECTED TARGET HS of BP:*Que que o João gosta de?

OR P-deletion

Que (que) o João gosta?

POSSIBLE ANSWER: De chocolate.

(3) O Cebolinha comeu o bolo de...

D. A. M. Cebolinha ate ( $3^{\text {rd }}$.S. Past Perf.) D. A. M. cake of...

TARGET BP: $\quad$ *De que (que) o Cebolinha comeu o bolo?

O Cebolinha comeu o bolo de que?

EXPECTED TARGET HS of BP:*Que que o Cebolinha comeu o bolo de?

POSSIBLE ANSWER: De morango.

(4) A Magali tomou o copo de...

D. A. M. Magali drank ( $3^{\text {rd }}$.S. Past Perf.) D. A. M. glass of....

TARGET BP: $\quad$ A Magali tomou o copo de quê?

*De que (que) a Magali tomou o copo?

EXPECTED TARGET HS of BP: *Que (que) a Magali tomou um copo de?

POSSIBLE ANSWER: De suco de laranja.

(5) O Chico Bento tomou a xícara de...

D. A. M. Chico Bento $\quad \operatorname{drank}\left(3^{r d}{ }^{\text {.S. Past Perf. })} \quad\right.$ D. A. F. cup of...

TARGET BP: $\quad$ O Chico Bento tomou a xícara de quê?

*De que (que) o Chico Bento tomou a xícara?

EXPECTED TARGET HS of BP:*Que (que) o Chico Bento tomou a xícara de?

POSSIBLE ANSWER: De café.

(6) A Mônica comeu o prato de...

D. A. F. Mônica ate ( $3^{\text {rd }}$.S. Past Perf. $) \quad$ D. A. M. plate of....

TARGET BP: $\quad$ A Mônica comeu o prato de quê?

*De que (que) a Mônica comeu o prato?

EXPECTED TARGET HS of BP: *Que (que) a Mônica comeu o prato de?

POSSIBLE ANSWER: De feijão com arroz. 
(7) A Magali falou

D. A. F. Magali talked ( $3^{\text {rd }}$.S. Pats Perf) of that (M.) video game.

TARGET BP: De qual/de que video-game (que) a Magali falou?

EXPECTED TARGET HS of BP:*Qual/que video-game (que) a Magali falou de?

POSSIBLE ANSWER: Do Let's Dance.

(8) O Cebolinha falou com a...

D. A. M. Cebolinha talked ( $3^{\text {rd }}$.S. Past Perf.) with D. A. F...

TARGET BP: Com quem (que) o Cebolinha falou?

EXPECTED TARGET HS of BP:*Quem (que) o Cebolinha falou com?

POSSIBLE ANSWER: Com a Magali.

(9) A Magali brincou com o...

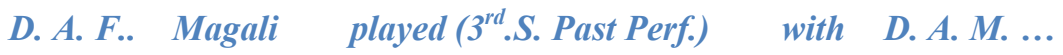

TARGET BP: $\quad$ Com quem (que) a Magali brincou?

EXPECTED TARGET HS of BP:*Quem que a Magali brincou com?

POSSIBLE ANSWER: Com o Cascão.

(10) A Mônica (es)tá falando faquele filme.

D. A. F. Mônica is ( ${ }^{\text {rd }}{ }^{\text {.S. }}$. Pres.) talking (Gerund) of that(M.) movie.

TARGET BP: De qual/de que filme a Mônica (es)tá falando?

EXPECTED TARGET HS of BP:*Qual/que filme (que) a Mônica (es)tá falando de?

POSSIBLE ANSWER: Do Transformers.

(11) A Magali foi ao cinema com o...

D. A. F. Magali went ( $3^{\text {rd }}{ }_{0}$ S. Past Perfo) to $+D . A_{0}$. M. movie(s) with the...

TARGET BP: $\quad$ Com quem (que) a Magali foi ao cinema?

EXPECTED TARGET HS of BP:*Quem (que) a Magali foi no cinema com?

POSSIBLE ANSWER: Com o Cascão.

(12) O Cascão vendou a bicicleta pro...

D. A. M. José sold (3 ${ }^{\text {rd }}$.S. Past. Perf.) D. A. F. bicicleta to + D. A. M.

TARGET BP: $\quad$ Para quem (que) o Cascão vendeu o bicicleta?

EXPECTED TARGET HS of BP:*Quem (que) o Cascão vendeu o bicicleta pra?

POSSIBLE ANSWER: Pro Cebolinha.

(13) A Mônica (es)tá correndo atrás do...

D. A. F. Mônica is ( $3^{\text {rd }}$.S. Pres. $)$ running after of + D. A. M. ...

TARGET BP: ?De quem (que) a Mônica tá correndo atrás?

EXPECTED TARGET HS of BP:*Quem (que) a Mônica tá correndo atrás de?

POSSIBLE ANSWER: Do Cebolinha.

(14) O Chico Bento mora naquela casa.

D. A. M. Chico Bento lives $\left(3^{\text {rd }}\right.$.S. Pres.) in that (F.) house.

TARGET BP: $\quad$ Em qual casa (que) o Chico Bento mora?

EXPECTED TARGET HS of BP:*Qual casa que o Chico Bento mora em?

OR P-deletion * * Qual casa (que) o Chico Bento mora?

POSSIBLE ANSWER: Na casa amarela. 
(15)
$\mathrm{O}$

$$
\text { Cascão (es)tá }
$$
namorando
com
a...
D. A. M.
Cascão
is $\left(3^{r d} \cdot\right.$ S. Pres. $)$
dating (Gerund)
with
D. A. F...

TARGET BP: Com quem (que) o Cscão tá namorando?

EXPECTED TARGET HS of BP:*Quem (que) o Cascão tá namorando com?

OR P-deletion

POSSIBLE ANSWER:

(16)

D. A. M. Chico Bento

TARGET BP:

EXPECTED TARGET HS of BP:*Qual/que árvore (que) o Chico Bento subiu em?

OR P-deletion

POSSIBLE ANSWER:

Quem (que) o Cascão tá namorando?

Com a Magali.

$$
\begin{array}{lcc}
\text { subiu naquela } & \text { árvore.. } \\
\text { climbed }\left(3^{\text {rd }} . \text { S. Past Perf. }\right) & \text { on }+ \text { that }\left(F_{0}\right) \quad \text { tree ... }
\end{array}
$$

Em qual árvore (que) o Chico Bento subiu?

* __ Qual/que árvore (que) o Chico Bento subiu?

Na mangueira.

(17) A Mônica

D. A. F. Mônica

TARGET BP:
viajou $\quad$ pra... travelled $\left(3^{\text {rd }} \cdot\right.$.S. Past Perf.) to ...

Para onde (que) a Mônica viajou?

EXPECTED TARGET HS of BP:*Onde (que) a Mônica viajou para/pra?

POSSIBLE ANSWER: Pro Brasil.

(18) Este

$$
\text { bolo é pra... }
$$

Def. Dem. Pron. M. cake is to/for ...

TARGET BP: $\quad$ Para quem/para que (que) é este bolo?

EXPECTED TARGET HS of BP:*Quem/que (que) é este bolo pra?

POSSIBLE ANSWER: Pra Ana/Pra sobremesa.

(19) A Magali (es)tá rindo do...

D. A. F. Magali is ( $3^{r d}$.S. Pres.) laughing (Gerund) at + D. A. M. ...

TARGET BP: De quem (que) a Maria tá rindo?

EXPECTED TARGET HS of BP:*Quem (que) a Maria tá rindo de?

POSSIBLE ANSWER: Do Cascão.

(20) O Chico Bento deu um livro pra...

D. A. M. Chico Bento gave ( $3^{\text {rd }}$.S. Past Perf. $)$ a (I.D.M.) book to ...

TARGET BP: $\quad$ Para quem (que) o José deu um livro?

EXPECTED TARGET HS of BP:*Quem que o José deu um livro pra?

POSSIBLE ANSWER: Pra Maria. 
The ' $Q U$-game’: Filler Sentences

(1) A Mônica falou que...

D. A. F. Mônica said ( $3^{\text {rd }}{ }^{. S}$. Past Perf.) that ...

TARGET BP and HS of BP: O que/Que (que) a Mônica falou?

POSSIBLE ANSWER: Gosta de chocolate.

(2) $\mathrm{O}$ Cebolinha gosta de jogar...

D. A. M. Cebolinha likes ( $3^{\text {rd }}$. S. Pres.) of play (Infinitive)...

TARGET BP and HS of BP: O que/que (que) o Cebolinha gosta de jogar?

POSSIBLE ANSWER: Futebol

(3) $\mathrm{O}$ gatinho tomou $\quad$ o...

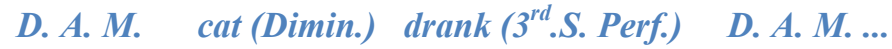

TARGET BP and HS of BP: O que/Que (que) o gatinho tomou? POSSIBLE ANSWER: O leite.

(4) A Magali viu o...

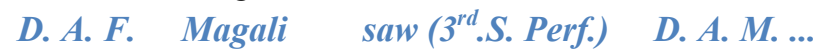

TARGET BP and HS of BP: Quem (que) a Magali viu? POSSIBLE ANSWER: O Mingau.

(5) $\mathrm{O}$ Cascão comeu um...

D. A. M. Cascão ate ( $3^{r d}$.S. Perf.) I. A. M....

TARGET BP and HS of BP: O que (que) o Cascão comeu?

POSSIBLE ANSWER: Pão-de-queijo

(6) A Mônica comprou uma...

D. A. F. Mônica bought ( $3^{\text {rd }}$.S. Perf.) I. A. F...

TARGET BP and HS of BP: O que (que) a Mônica comprou?

POSSIBLE ANSWER: Uma boneca.

(7) A Magali chegou na...

D. A. F. Magali arrived ( $3^{\text {rd }} . S_{0}$ Perf. $)$ at/in + D. A. F. ...

TARGET BP and HS of BP: Aonde/Onde (que) a Magali chegou? POSSIBLE ANSWER: Na praia.

(8) $\mathrm{O}$ Chico Bento chutou a...

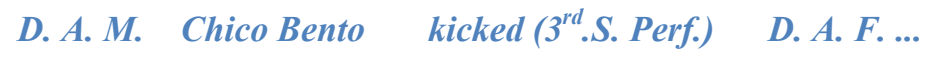

TARGET BP and HS of BP: O que (que) o Chico Bento chutou? POSSIBLE ANSWER: A bola.

(9) A Mônica mora no...

D. A. M. Mônica lives ( ${ }^{\text {rd }}{ }^{\text {.S S. Perf. }) ~} \quad$ in + D. A. M...

TARGET BP and HS of BP: Onde (que) a Mônica mora?

POSSIBLE ANSWER: No Brasil

(10) $\mathrm{O}$ cachorro mordeu a...

D. A. M. Bidu bit ( $3^{r d}$.S. Perf. $) \quad$ D. A. M....

TARGET BP and HS of BP: Quem (que) o Bidu mordeu?

POSSIBLE ANSWER: A Magali. 


\begin{tabular}{l} 
S A M P L E - E X E M P L O \\
A Mônica falou com o ... \\
TARGET: Com quem (que) a Mônica falou? \\
O Cascăo tá brincando com aquela menina. \\
TARGET: Com (que) menina que o Cascăo tá brincandondo? \\
\hline
\end{tabular}
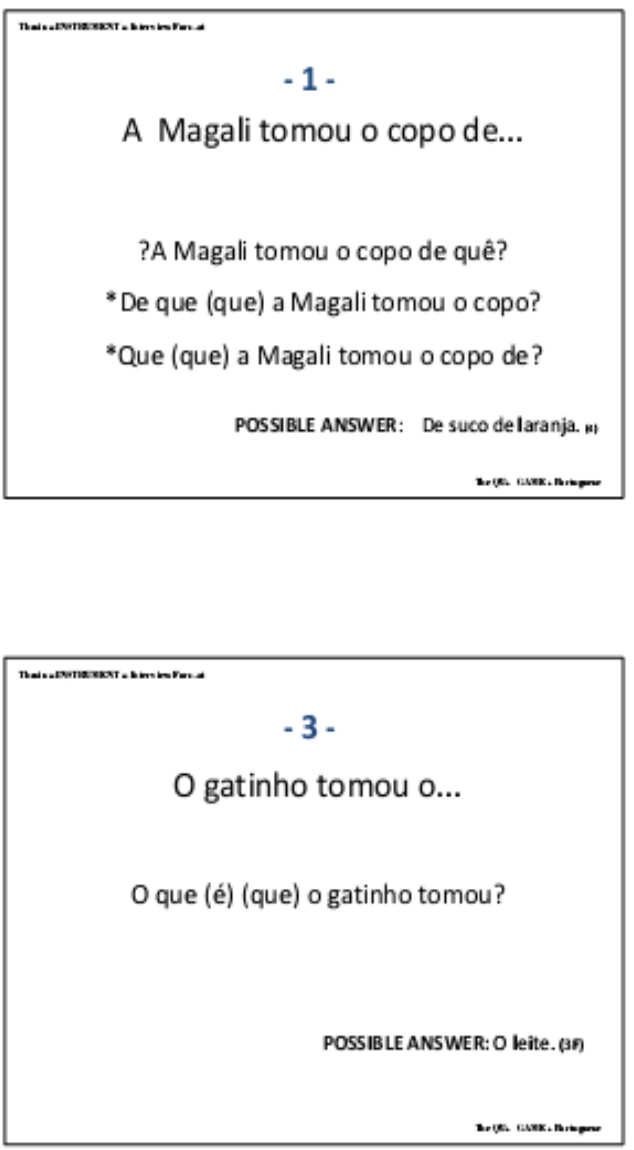

Pra que (que) é este bolo?

*Que (que) é este bolo pra?

POSSIBLE ANSWER: De chocolate.[1

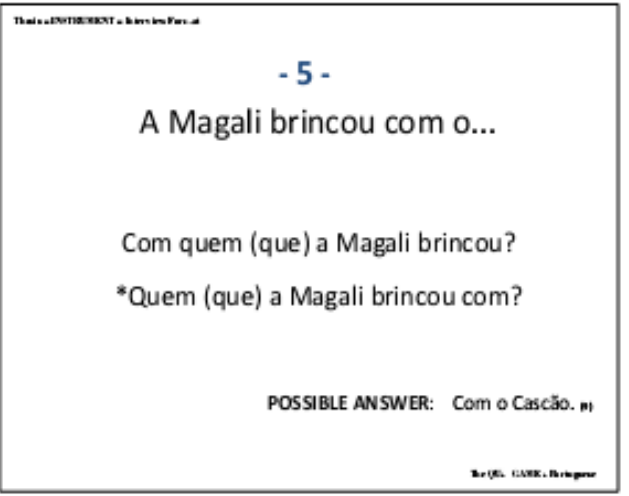




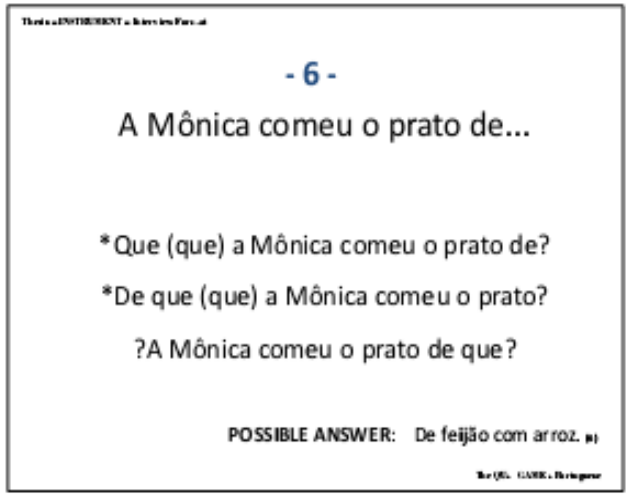

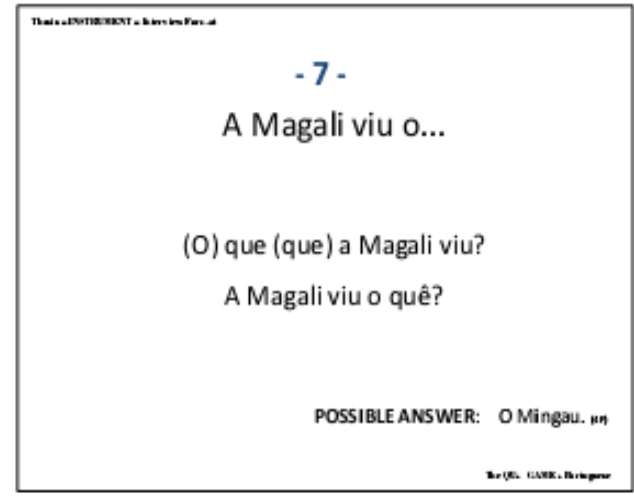

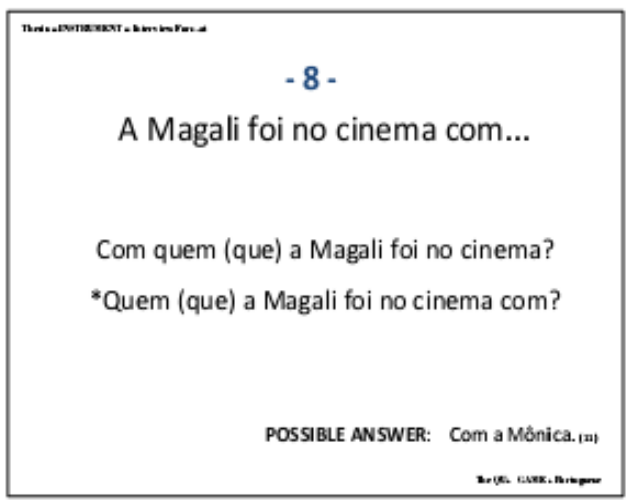

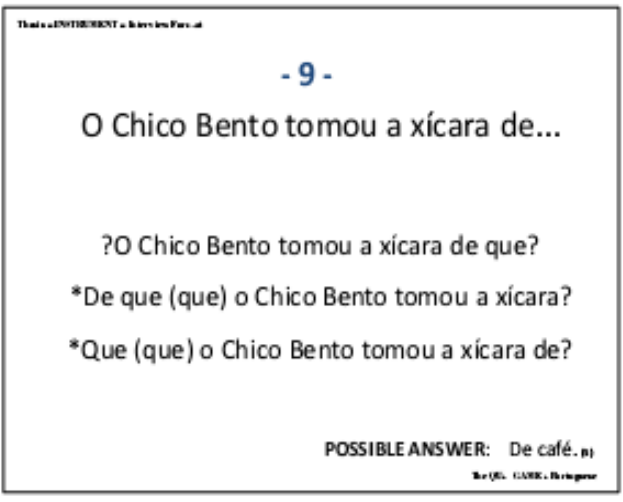

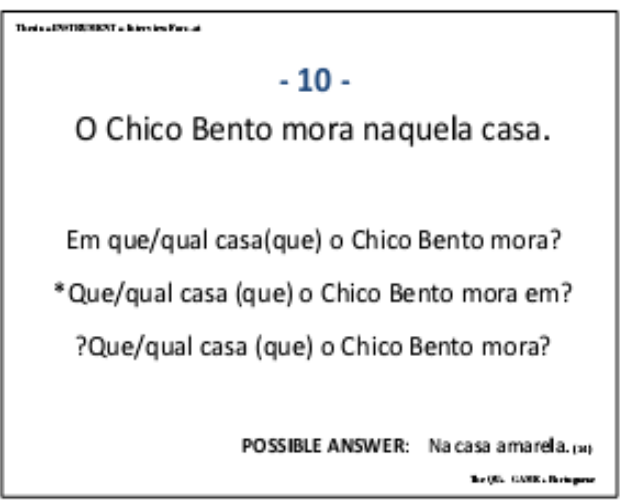

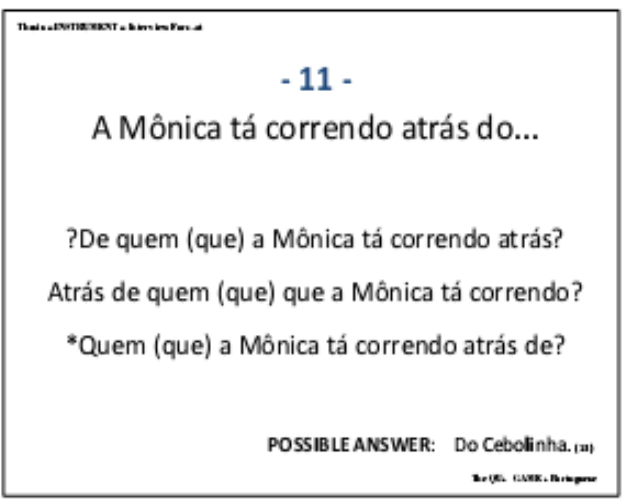




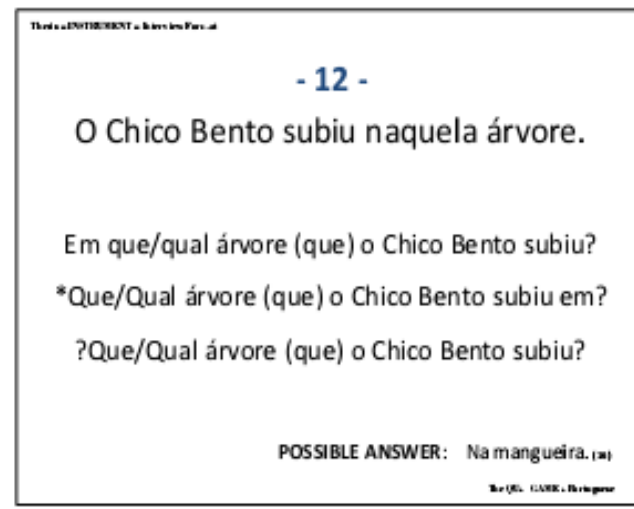

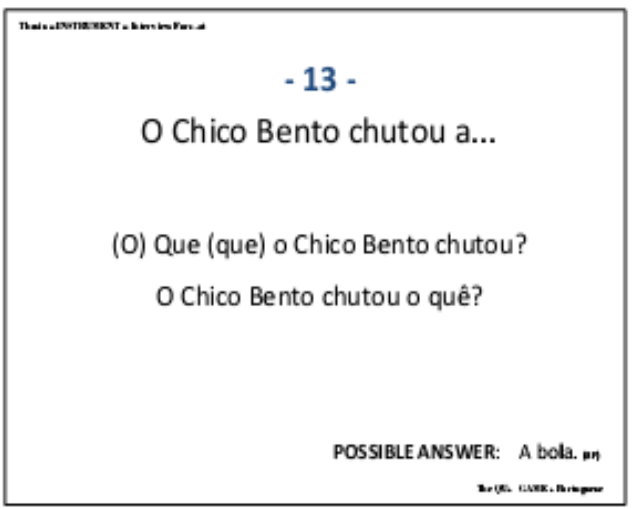

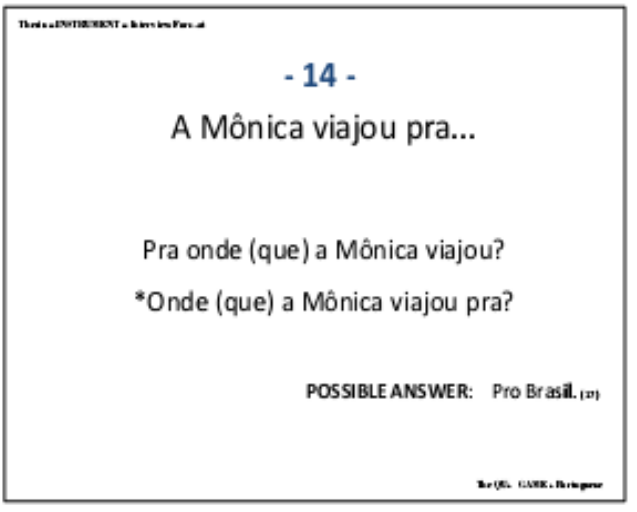
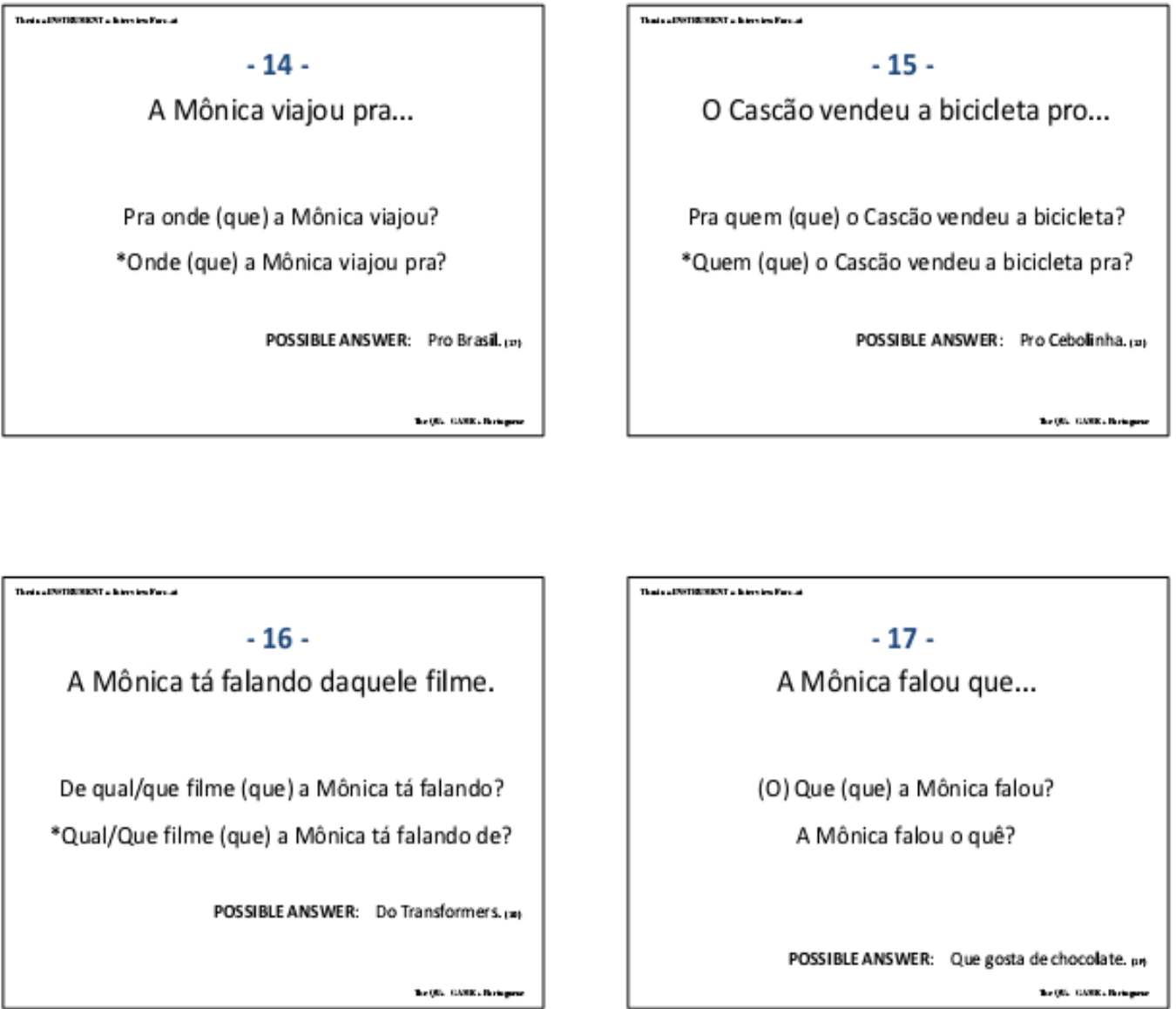

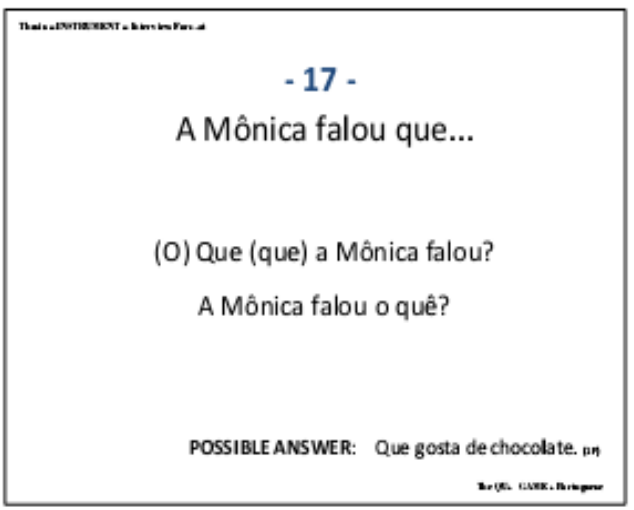



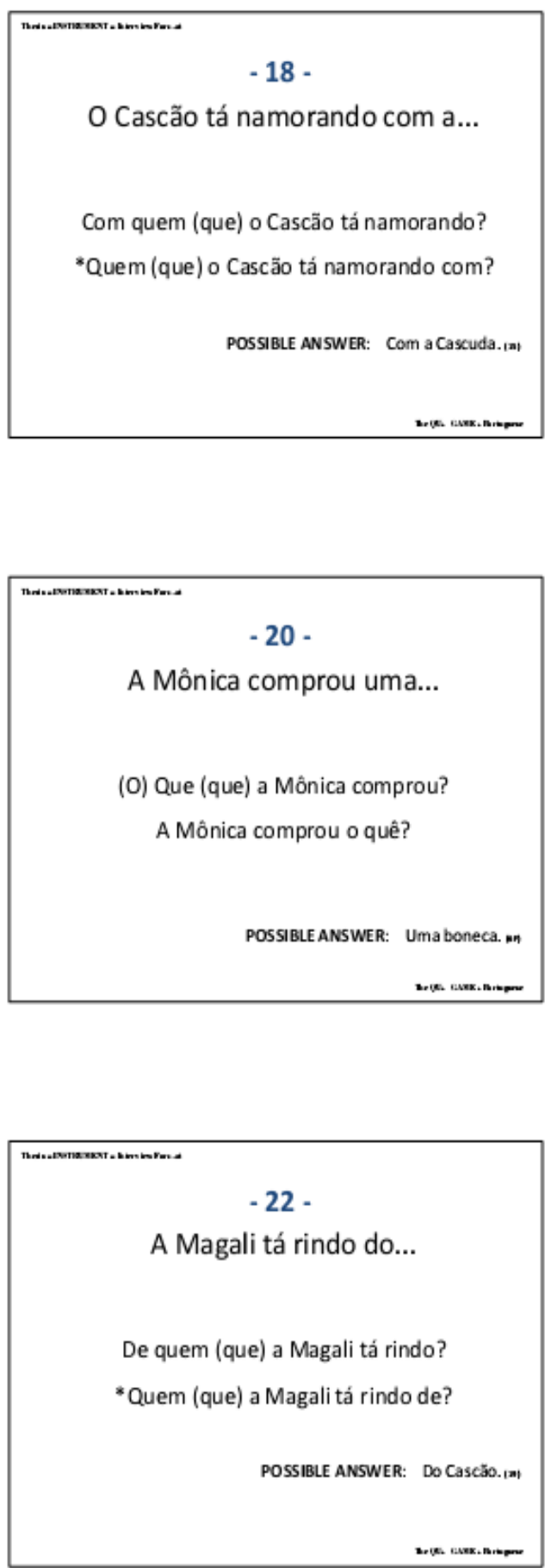
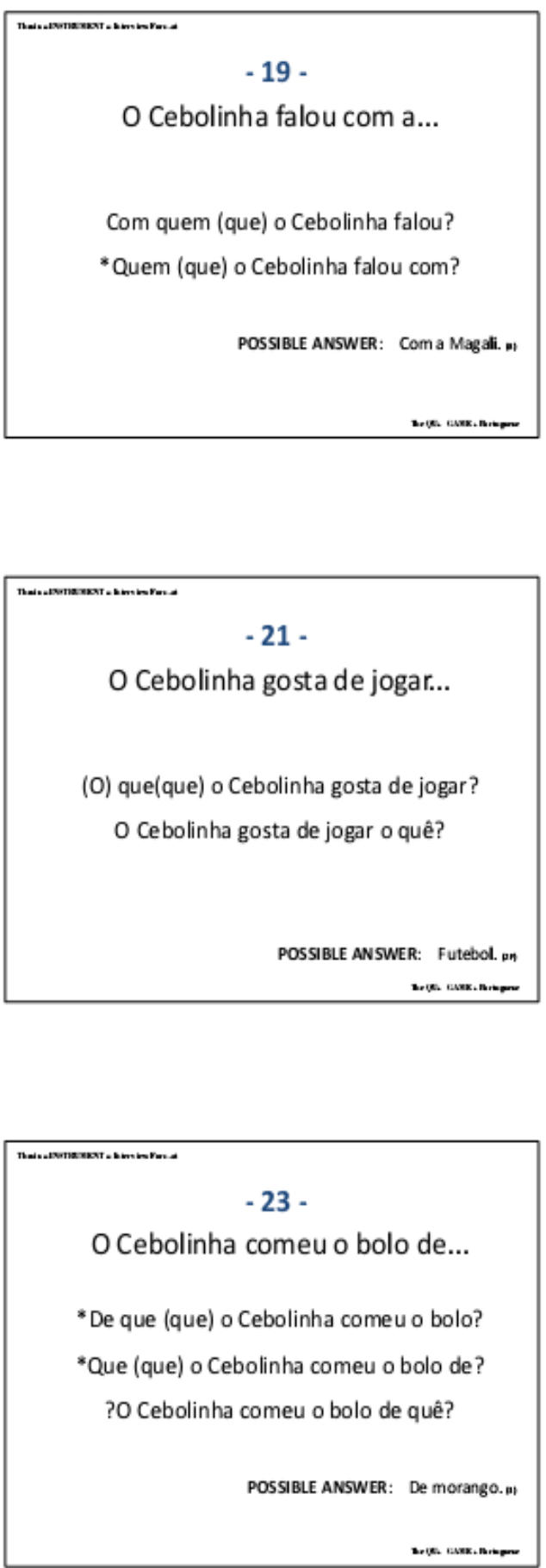

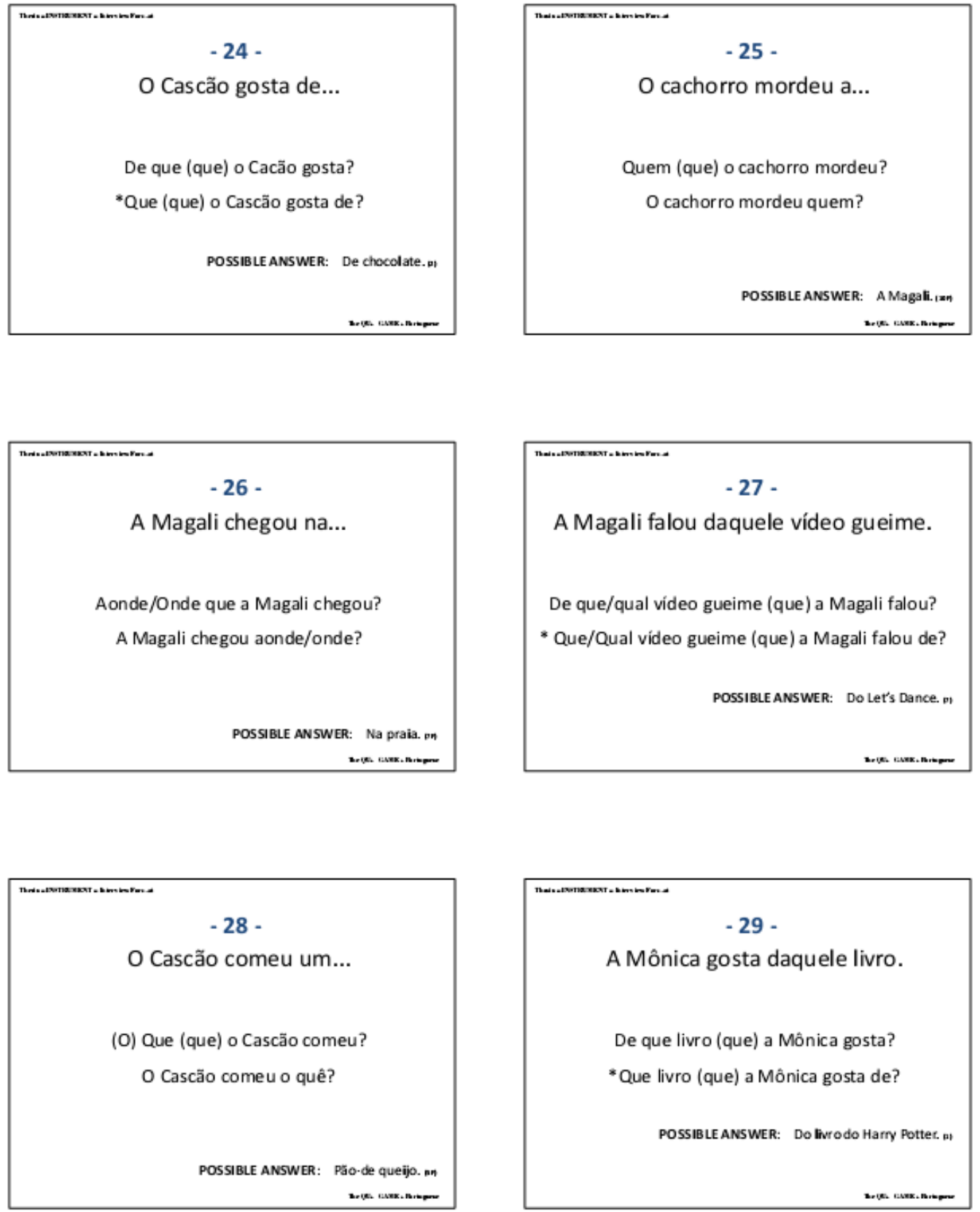

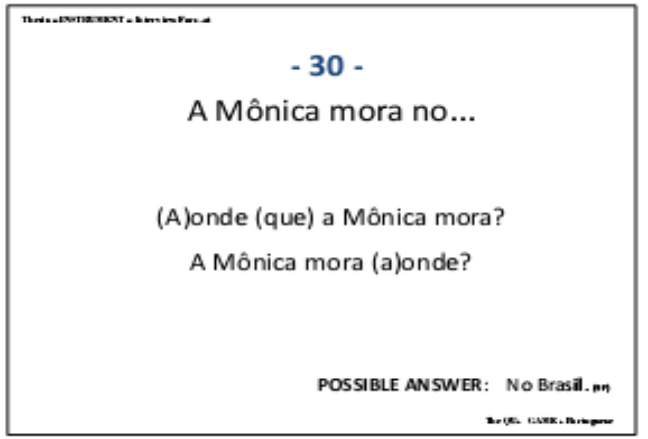


Appendix 2 - The ' $W H$ - Game': Target \& Filler Sentences 
The questions below were also scrambled using the algorithm in random.org. These are the translations of the Portuguese sentences from the ' $Q U$-game', where possible.

(1) Carly likes that book.

TARGET:

Which book does Carly like?

(2) Fred likes .....

TARGET: What does Fred like?

(3) Sam took the picture of...

TARGET: $\quad$ *Who did Sam take the picture of?

(4) Tori drank the glass of...

TARGET: $\quad$ *What did Tori drink the glass of?

(5) Beck drank the cup of...

TARGET: $\quad$ *What did Beck drink the cup of?

(6) Cat ate the plate of...

TARGET: $\quad$ *What did Cat eat the plate of?

(7) Carly talked about that video-game.

TARGET: What video-game did Carly talk about?

(8) Fred talked to...

TARGET: Who did Fred talk to?

(9) Sam played with...

TARGET: Who did Sam play with?

(10) Tory is talking about that toy.

TARGET: Which toy is Tory talking about?

(11) Andre went to the movies with.....

TARGET: Who did Andre go to the movies with?

(12) Jade sold the video-game to...

TARGET: Who did Jade sell the video-game to?

(13) Beck is running after...

TARGET: Who is Beck running after?

(14) Cat sleeps in that room.

TARGET: Which room does Cat sleep in? 
(15) Carly is going out with...

TARGET: Who is Carly going out with?

(16) Spencer climbed on that tree.

TARGET : Which tree did Spencer climb on?

(17) Sam travelled to...

TARGET: Where did Sam travel to?

(18) This cake is for...

TARGET: Who/what is this cake for?

(19) Andre is laughing at...

TARGET: Who is Andre laughing at?

(20) Spencer gave the book to...

TARGET: Who did Spencer give the book to? 


\section{The 'WH- Game’: Filler Sentences}

(1) Fred said that...

TARGET:

POSSIBLE ANSWER:

(2) Beck likes to play...

TARGET:

POSSIBLE ANSWER:

(3) The cat drank the...

TARGET:

POSSIBLE ANSWER:

(4) Tory saw the...

TARGET:

POSSIBLE ANSWER:

(5) Jade ate a...

TARGET:

What did Jade eat?

POSSIBLE ANSWER:
What did Fred say?

She likes chocolate.

What does Beck like to play?

Soccer.

What did the cat drink?

The milk.

What did Tory see?

She saw new video game.

(6) Carly bought a...

TARGET: What did Carly buy?

POSSIBLE ANSWER: A toy

(7) Cat arrived this...

TARGET BP and HS of BP: When did Cat arrive?

POSSIBLE ANSWER: This morning.

(8) Sam kicked the...

TARGET BP and HS of BP: What did Sam kick?

POSSIBLE ANSWER: The ball

(9) Carly lives in...

TARGET BP and HS of BP: Where does Carly live?

POSSIBLE ANSWER: In Brazil

(10) The dog bit the...

TARGET BP and HS of BP: Who did the dog bite?

POSSIBLE ANSWER: Ana 
Appendix 3 - The "Puppet-Game" Portuguese 


S A M P LE - E XE M P L O
TARGET: * Quem que a Maria falou com?
TARGET: Com quem que a Maria falou?
TARGET: * Quem que o Cascão tá brincando com?
TARGET: Com quem que o Cascão tá brincando?

1: Onde (que) a Magali chegou?
2: A Magali chegou onde?
POSSIBLE ANSWER: Na praia. pn

\begin{tabular}{|c|c|}
\hline \multicolumn{2}{|l|}{$-4-$} \\
\hline \multicolumn{2}{|l|}{ 1: Com quem (que) a Magali brincou? } \\
\hline \multicolumn{2}{|l|}{ 2: *Quem (que) a Magali brincou com? } \\
\hline POSSIBLE ANSWER: & Com o Cascăo. m \\
\hline & 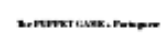 \\
\hline
\end{tabular}
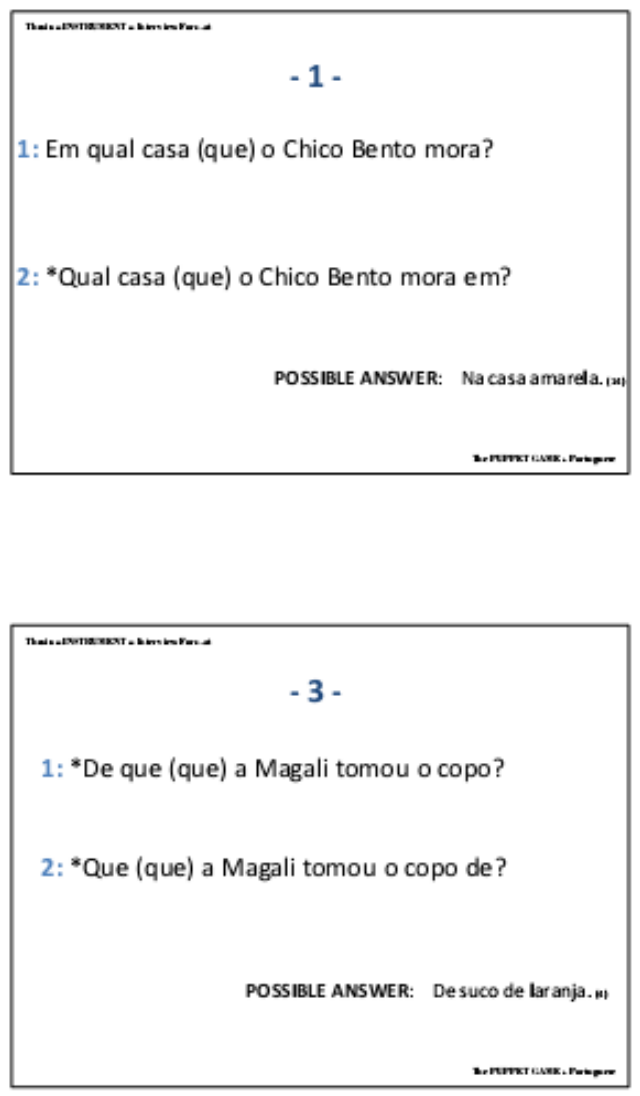

1: Que (que) o Chico Bento chutou?
2: O Chico Bento chutou o quê?
POSSIBLE ANSWER: A bola. nn




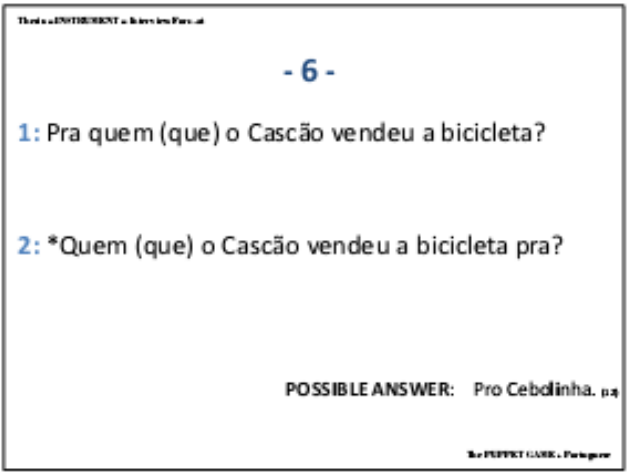

\begin{tabular}{|c|}
\hline 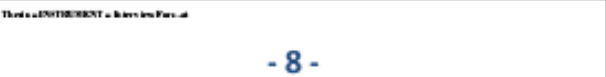 \\
\hline 1: O que (que) o Cebolinha gosta de jogar? \\
\hline 2: O Cebolinha gosta de jogar o quê? \\
\hline POSSIBLE ANSWER: Futebol. pn \\
\hline 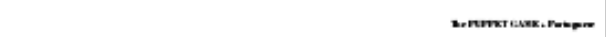 \\
\hline
\end{tabular}

1: Pra que (que) é este bolo?
2: * Que (que) é este bolo pra?
possible Answer: Pro aniversário da Mönica.tio
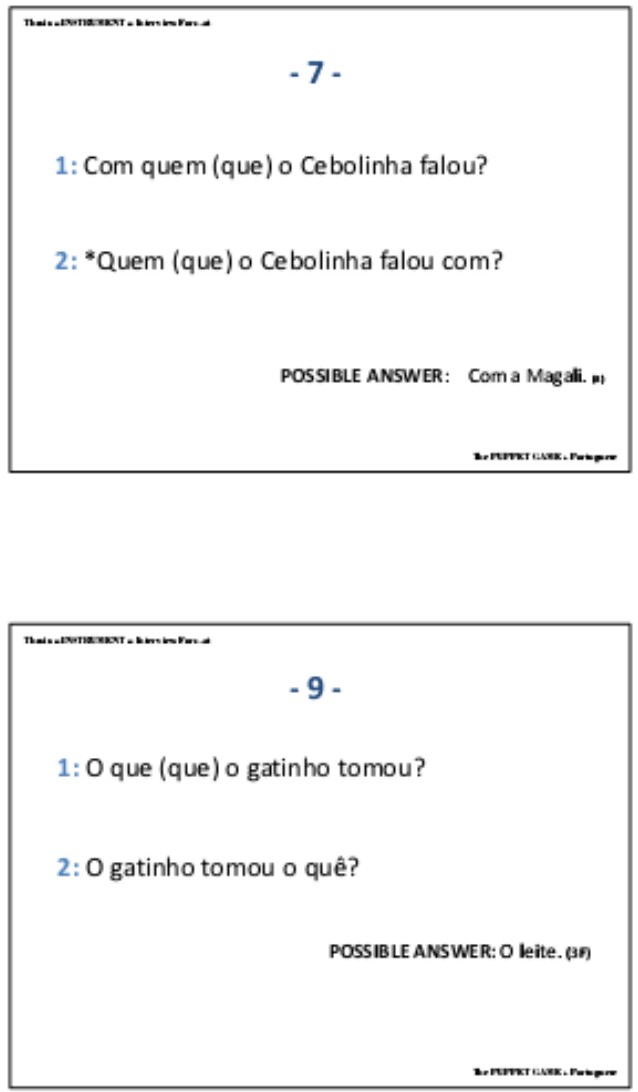

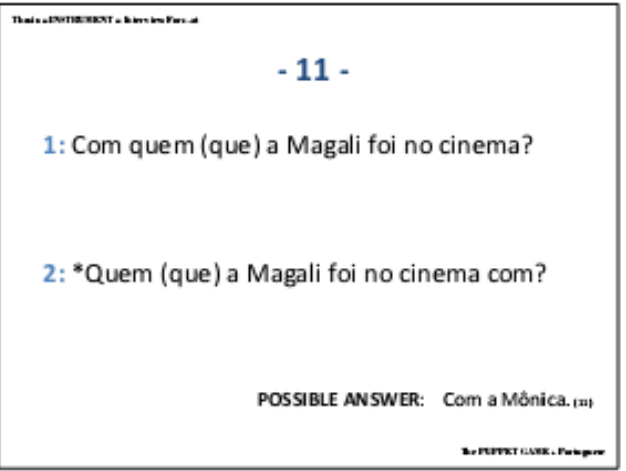




1: (A)onde (que) a Mônica mora?
2: A Mônica mora (a)onde?
POSSIBLE ANSWER: No Brasil.nn

1: De qual filme (que) a Mônica tá falando?
2: *aual filme (que) a Mônica tá falando de?
POSSIBLE ANSWER: Do Transformers. nus

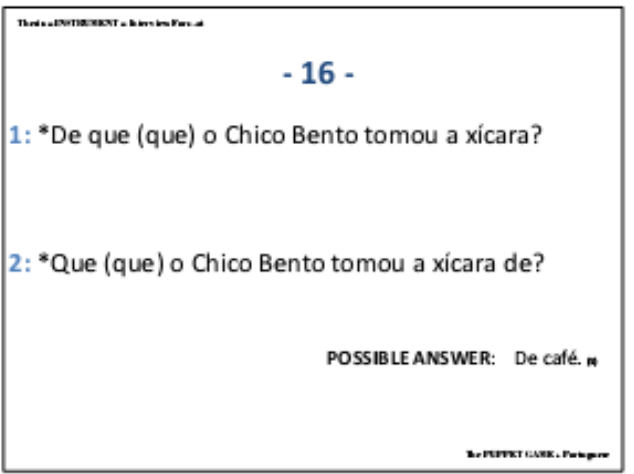

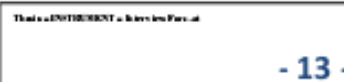

1: Em qual árvore (que) o Chico Bento subiu?

2: *Qual árvore (que) o Chico Bento subiu em?

POSSIBLE ANSWER: Na mangueira. p.

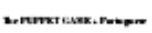

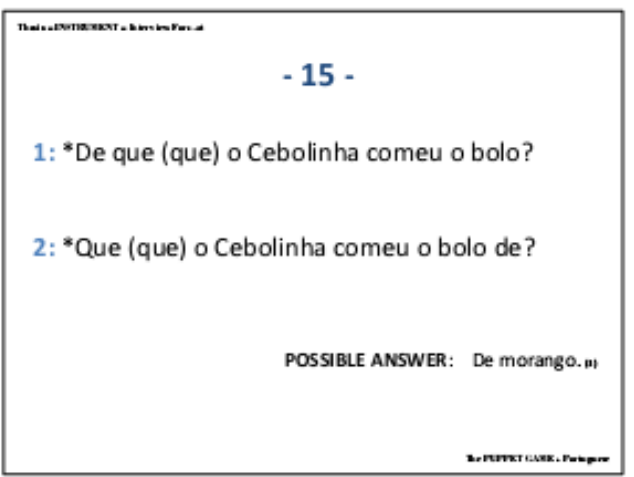

1: Pra onde (que) a Mônica viajou?
2: * Onde (que) a Mônica viajou pra?
POSSIBLE ANSWWER: Pro Brasil.|r|



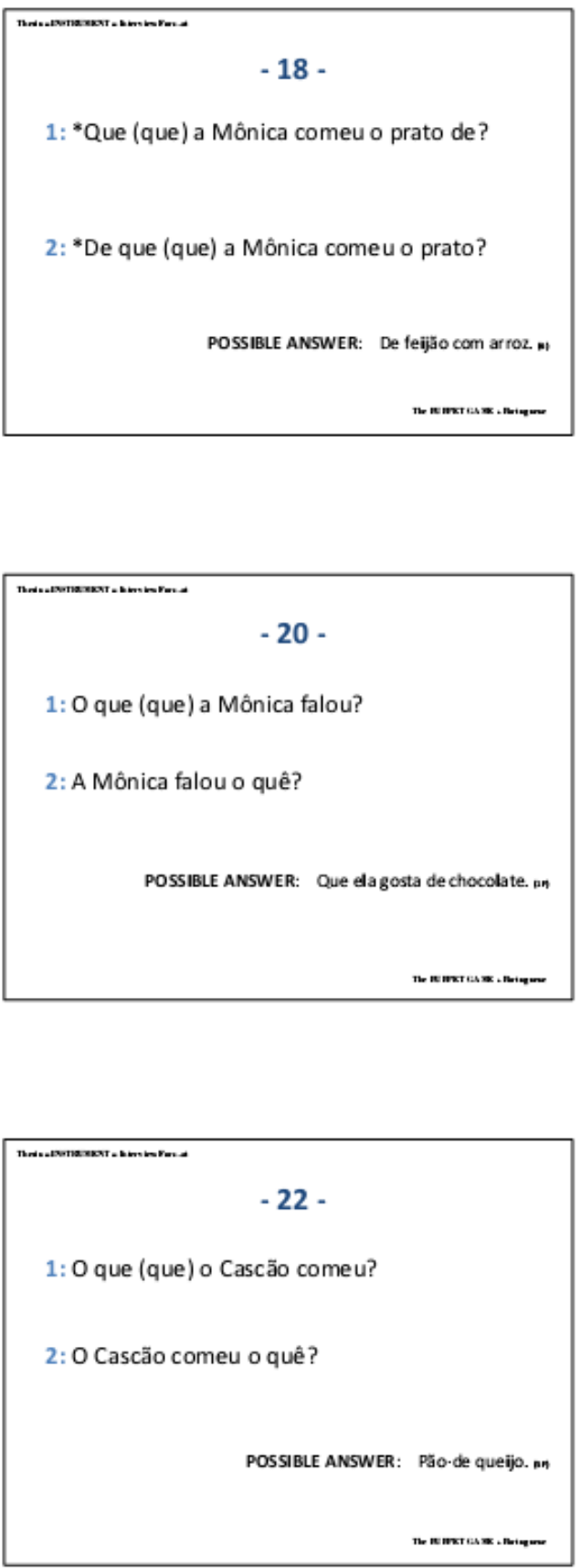
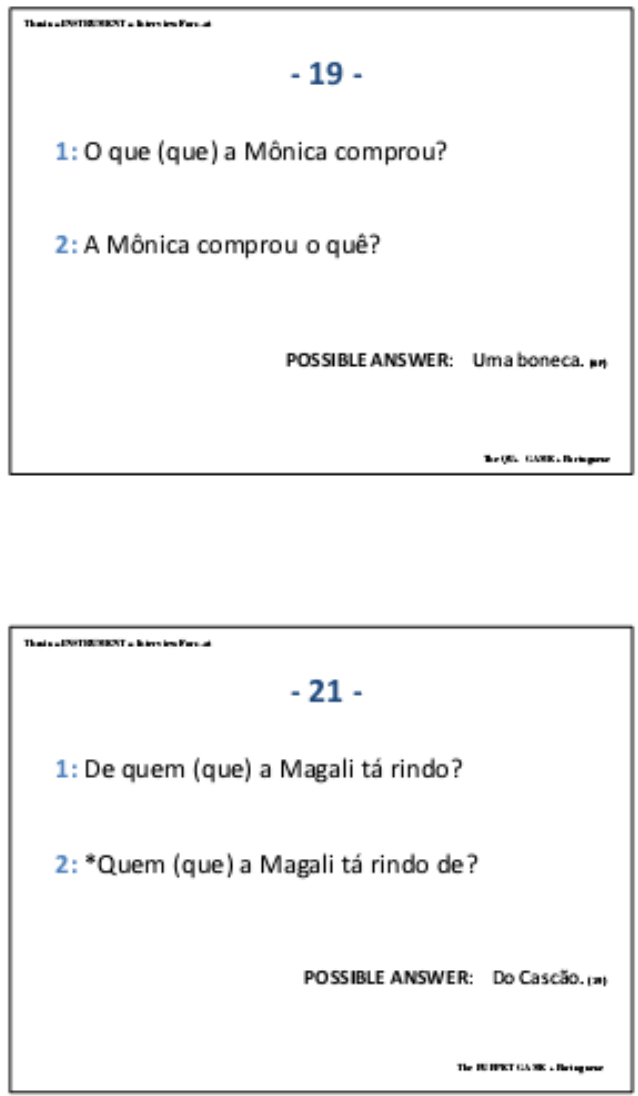

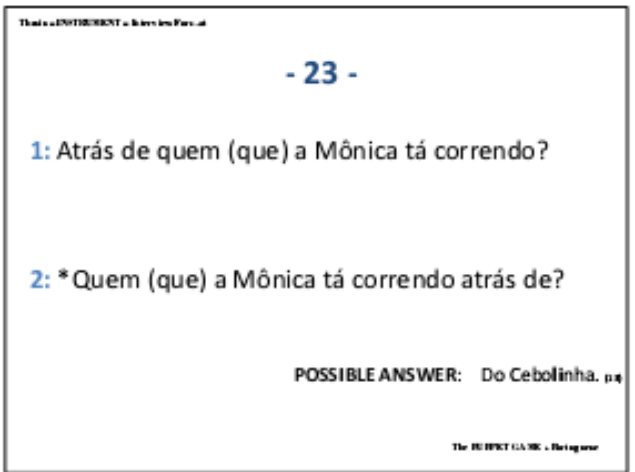




\begin{tabular}{|c|}
\hline 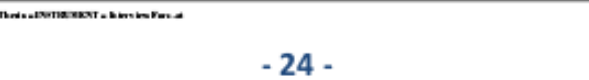 \\
\hline 1: O que (que) a Magali viu? \\
\hline 2: A Magali viu o quê? \\
\hline POSSIBLE ANSWER: O brinquedo nOwo da Mönica, un \\
\hline
\end{tabular}
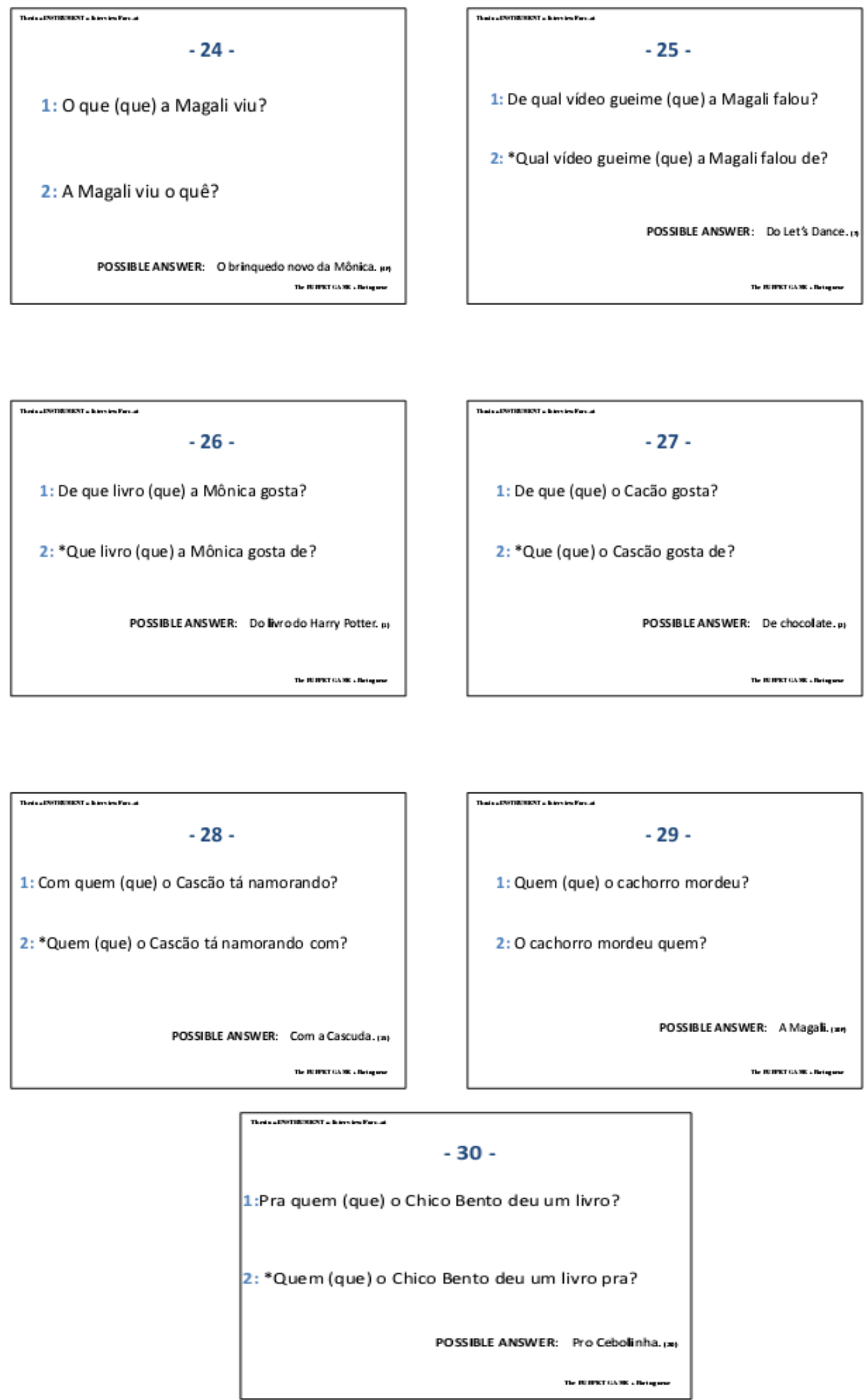
Appendix 4 - The "Puppet-Game" English 

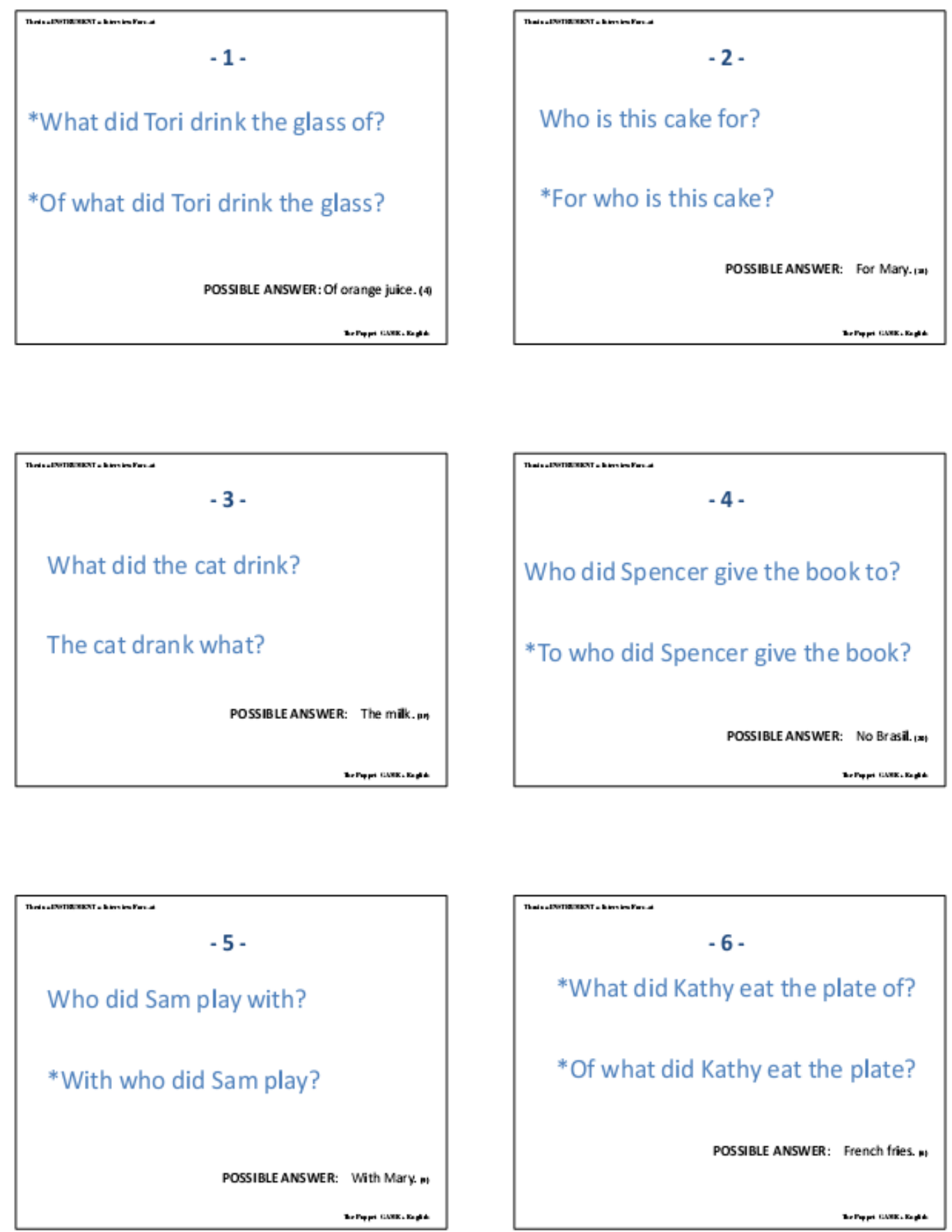

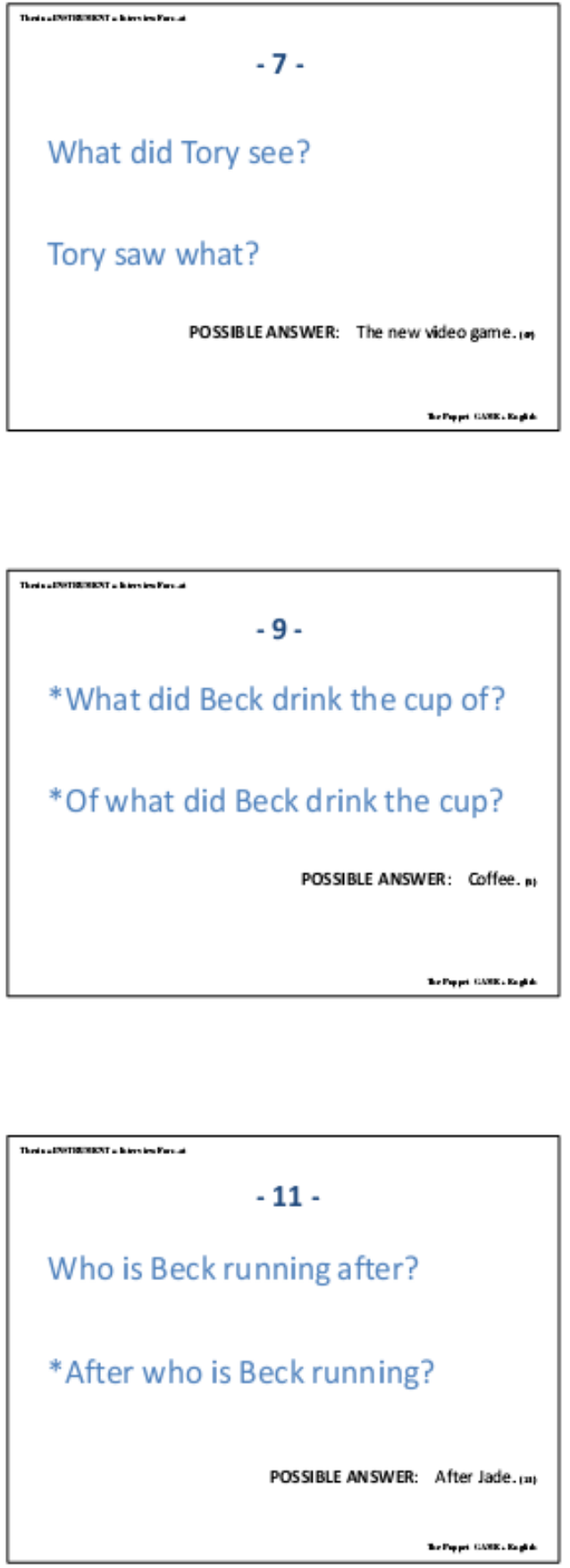
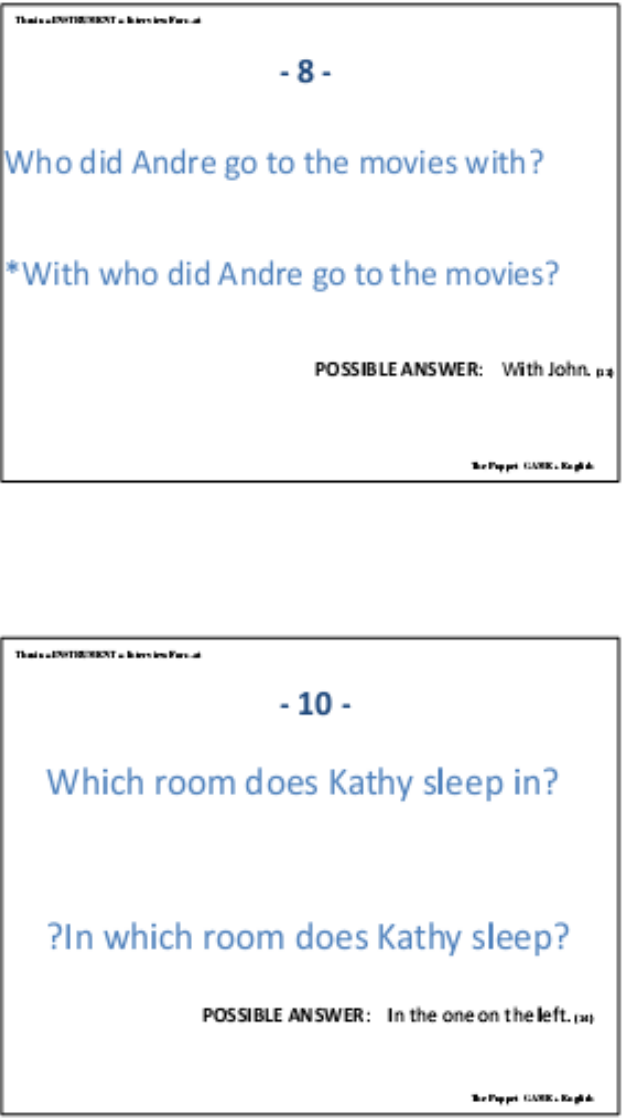

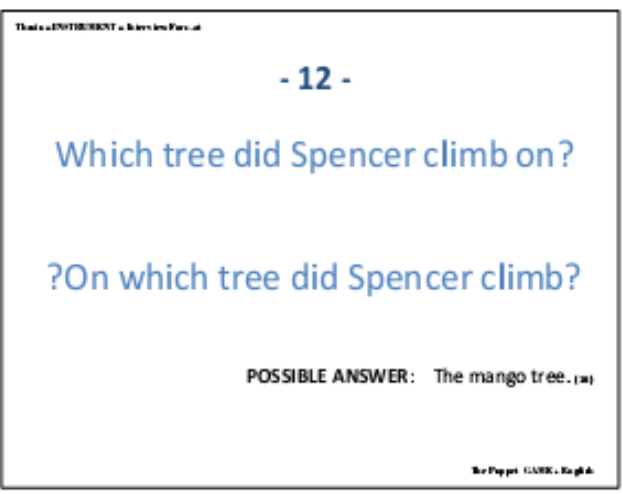



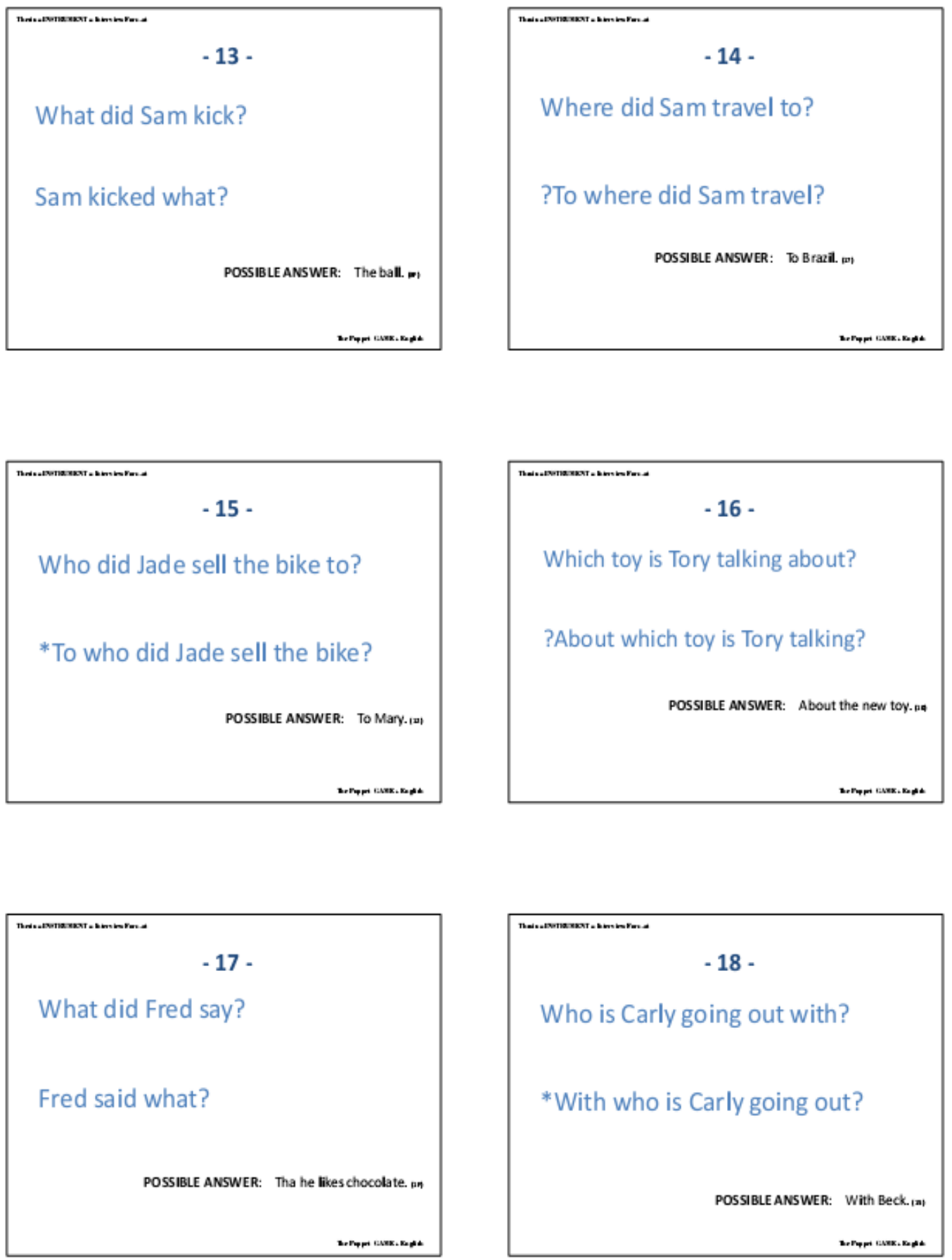

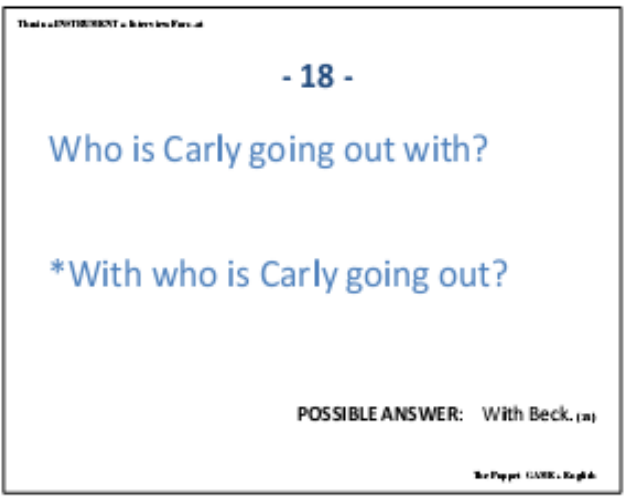



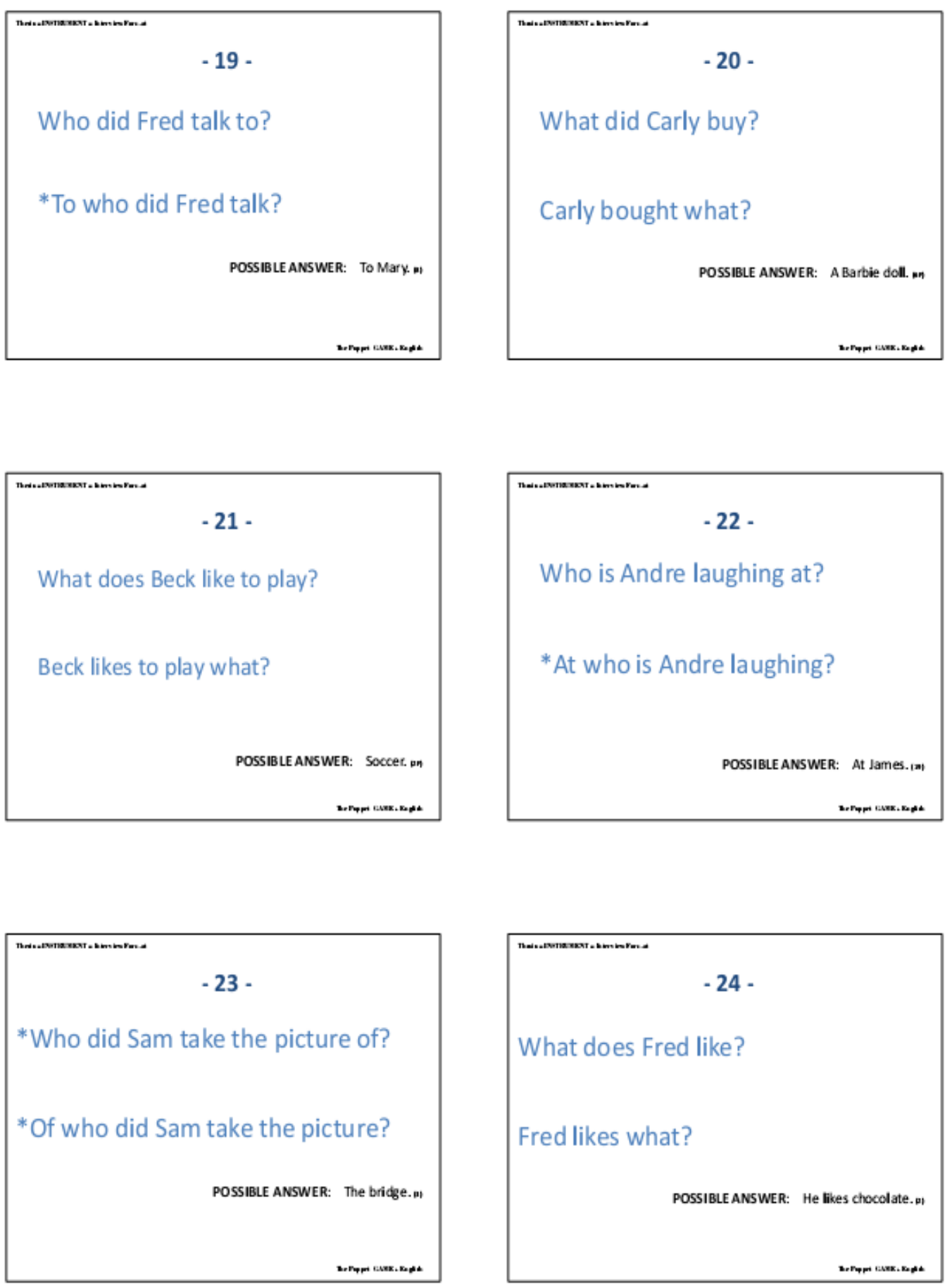

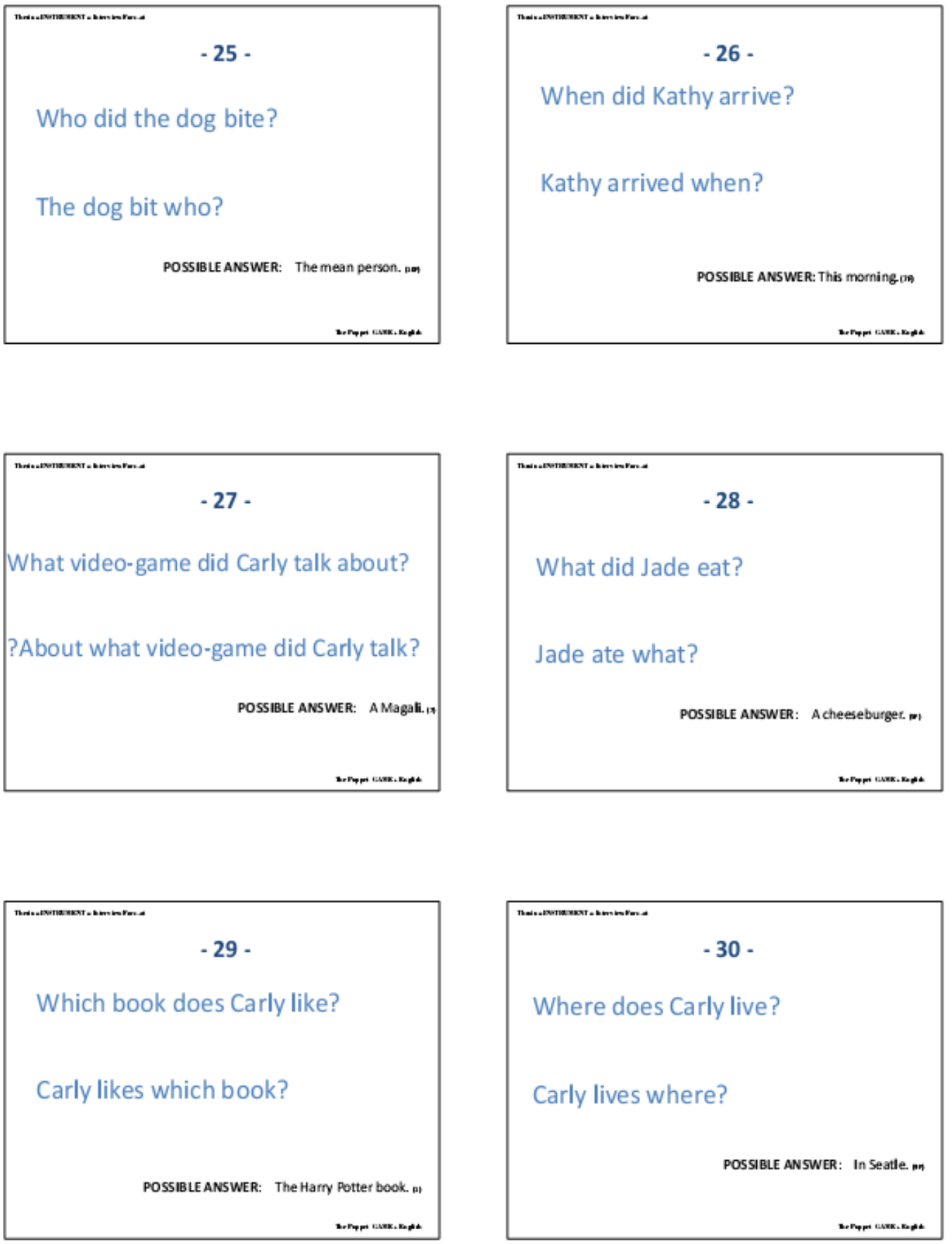
Appendix 5 - Language History Questionnaire 


\section{Language History Questionnaire for Families Questionário de Histórico Linguístico Para Famílias}

Please, fill out ALL questions in this questionnaire to the best of your knowledge. The answers to this questionnaire are part of a large study about Portuguese as a Heritage Language. Por favor, preencha todas as questões do questionário abaixo da melhor forma possível. As respostas do mesmo serão parte de um importante estudo sobre português como língua de herança.

\section{FAMILY INFORMATION - DADOS DA FAMÍLIA}

Contact's name: *Nome do contato:

Relationship with child (children): *Parentesco com a(s) criança(s):

E-mail address: *Endereço de email :

Telephone (000 000-0000):Telefone (000 000-0000):

Family's approximate annual income (whichever currency applies):Renda anual aproximada da família (na moeda que se aplique):

Does child (children) live with:A(s) criança(s) vivem com:
re 1. $\mathbb{C}$ Both parents - Ambos os pais
re 2. $\mathbb{C}$ Mother - Mãe
re 3. $\mathbf{C}$ Father - Pai
re 4. $\square$ Shared Custody - Custódia Compartilhada
re 5. $\square$ Other:

Does child (children) has (have) caregivers other than parents? Outra pessoa, além dos pais, cuida da(s) criança(s)?

C Baby sitter - Babá

C Grandparents - Avós

C Not applicable - Não se aplica

C Other:

If child (children) has (have) caregivers other than parents, what languages do these caregivers speak? Se outra pessoa, além dos pais, cuida da(s) criança(s), que línguas esta pessoa fala?

C Spanish - Espanhol

C Portuguese - Português

C English - Inglês

C Not applicable - Não se aplica

E Other: 
If you hear someone saying each of the Portuguese sentences below, how would grade them? (REMEMBER, WE ARE INTERESTED IN SPOKEN LANGUAGE, NOT IN WRITTEN LANGUAGE)Se você ouvisse alguém dizer as seguintes frases em português, como as classificaria? (LEMBRE-SE DE QUE ESTAMOS INTERESSADOS NA LÍNGUA FALADA, NÃO NA LÍNGUA ESCRITA)

\begin{tabular}{|c|c|c|c|}
\hline & $\begin{array}{l}\text { Unacceptable - } \\
\text { Inaceitável }\end{array}$ & $\begin{array}{c}\text { Odd, but acceptable } \\
\text { Estranha, mais aceitável }\end{array}$ & $\begin{array}{l}\text { Acceptable - } \\
\text { Aceitável }\end{array}$ \\
\hline "Mãe, quem que a gente vai no cinema com?" & C & $\mathrm{C}$ & E \\
\hline "Este tipo de comportamento, eu sou contra!" & $\mathrm{C}$ & C & C \\
\hline "Que que você gosta?" & E & $\boldsymbol{C}$ & C \\
\hline "Vó, que que é isso pra?" & $E$ & $\mathrm{C}$ & E \\
\hline "Pai, o chocolate que eu gosto de é este aí." & E & C & C \\
\hline
\end{tabular}

If you hear someone saying each of the English sentences below, how would grade them? (REMEMBER, WE ARE INTERESTED IN SPOKEN LANGUAGE, NOT IN WRITTEN LANGUAGE)Se você ouvisse alguém dizes as seguintes frases em inglês, como as classificaria? (LEMBRE-SE DE QUE ESTAMOS INTERESSADOS NA LÍNGUA FALADA, NÃO NA LÍNGUA ESCRITA)

\begin{tabular}{lccc}
\hline "Mom, who are we going to the movies with? " & $\begin{array}{c}\text { Unacceptable } \\
\text { - Inaceitável }\end{array}$ & $\begin{array}{c}\text { Odd, but acceptable } \\
\text { Estranha, mas aceitável }\end{array}$ & $\begin{array}{c}\text { Acceptable - } \\
\text { Aceitável }\end{array}$ \\
\hline "This kind of behavior, I am opposed to" & $\mathbf{C}$ & $\mathbf{C}$ & $\mathbf{C}$ \\
\hline "What do you like of?" & $\mathbf{C}$ & $\mathbf{C}$
\end{tabular}

Put the following words in order so that they form an acceptable question in Portuguese: almoçar / nós / com / vamos / quemColoque as seguintes palavras em ordem, de maneira que elas formem uma pergunta correta em português: almoçar / nós / com / vamos / quem

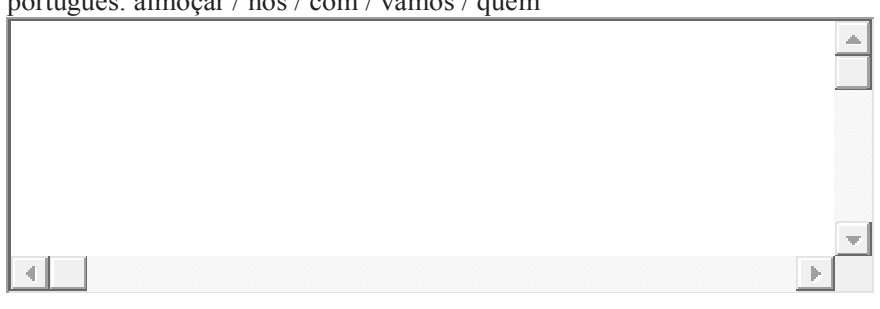

Put the following words in order so that they form an acceptable question in English (all words need to be used, no addtions necessary): movies / with / are / who / going / we / the / toColoque as seguintes palavras em ordem, de maneira que elas formem uma pergunta correta em inglês (todas as palavras têm que ser usadas, nenhuma adição é necessária): movies / with / are / who / going / we / the / to

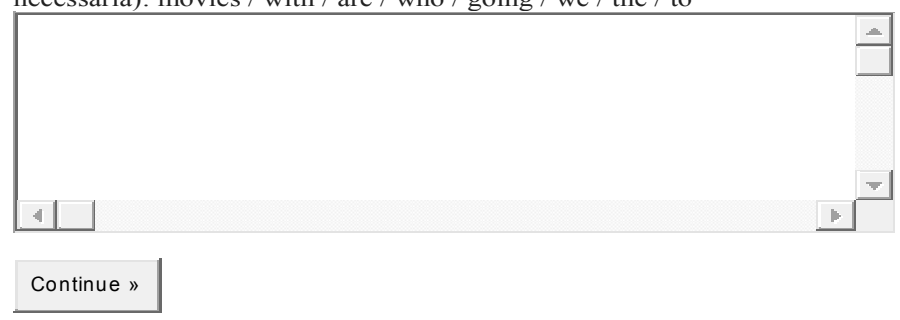




\section{Language History Questionnaire for Families - Questionário de Histórico Linguístico Para Famílias}

\section{PARENTS INFORMATION - DADOS DOS PAIS}

The questions in this section ask for information about you, the parents. Please answer them to the best of your knowledge. As questões desta seção pedem informações sobre vocês, os pais. Por favor responda a todas da melhor forma possível.

\section{MOTHER - MÃE}

The questions in this section ask for information about the child's mother. Please answer them to the best of your knowledge. As questões desta seção pedem informações sobre a mãe da criança. Por favor responda a todas da melhor forma possível.

Mother's age:Idade da mãe:

Mother's place of birth (city):Lugar de nascimento da mãe (cidade):

Mother's country of birth:País de nascimento da mãe:

Mother's education:Grau de escolaridade:

Mother's native language:Língua materna da mãe:

Other Languages mother speaks:Outras línguas que a mãe fala:

$\begin{array}{lll}\text { re 1. } & \text { Portuguese - Português } \\ \text { re 2. } & \square & \text { English - Inglês } \\ \text { re 3. } & \square & \text { French - Francês } \\ \text { re } 4 . & \square & \text { Italian - Italiano } \\ \text { re } 5 . & \square & \text { Spanish - Espanhol } \\ \text { re } 6 . & \square & \text { German - Alemão } \\ \text { re } 7 . & \square & \text { None } \\ \text { re } 8 . & \square & \text { Other: }\end{array}$

How long has mother lived in country of birth for? Por quanto tempo a mãe viveu no país onde nasceu?

Which countries has mother lived in other than the country of birth and the US? Em que países a mãe viveu, além do país no qual nasceu e dos Estados Unidos? 

português:

Since mother's arrival in the US, whenever mother is not using Portuguese, what other language(s) mother uses? Desde a chegada da mãe aos EUA, quando a mãe não está falando português, que outra(s) língua(s) a mãe fala?
re 1. $\square$ English - Inglês
re 2. $\quad$ English and other languages - Inglês e outras línguas
re 3. $\square$ Other - Outras

\section{Language History Questionnaire for Families - Questionário de Histórico Linguístico Para Famílias}

\section{FATHER - PAI}

The questions in this section ask for information about the child's father. Please answer them to the best of your knowledge. As questões desta seção pedem informações sobre o pai da criança. Por favor responda a todas da melhor forma possível.

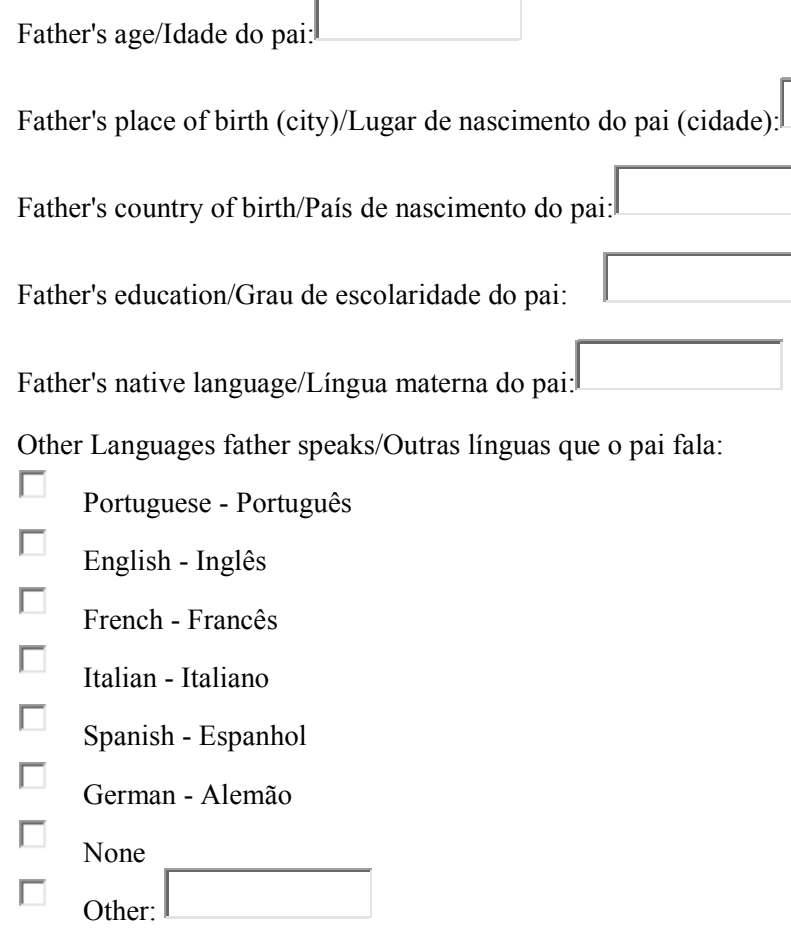

Since father's arrival in the US, whenever father is using Portuguese, what other language(s) father uses? Desde a chegada do pai aos EUA, quando o pai não está falando português, que outra(s) língua(s) o pai fala?
re 1. $\square$ English - Inglês
re 2. English and other languages - Inglês e outras línguas
re 3. $\mathrm{C}$ Other - Outras 


\section{Language History Questionnaire for Families Questionário de Histórico Linguístico Para Famílias}

* Required

\section{CHILD'S INFORMATION - DADOS DA CRIANÇA}

ALL questions in this section ask for information about your child and your child's language history. Please answer them to the best of your knowledge. TODAS as questões desta seção pedem informações sobre seu filho e o histórico linguístico de seu filho. Por favor responda a todas da melhor forma possível.

Child's Age *Idade da Criança

Child's place of birth (city): *Lugar de nascimento da criança(cidade):

Child's country of birth: *País de nascimento da criança:

If child wasn't born in the US, specify how old was the child upon arrival in the US/*Se a criança não nasceu nos Estados Unidos, que idade a mesma tinha quando chegou aos Estados Unidos:

Has the child lived in another country, other than the US?/*A criança já viveu em outros países, além dos Estados Unidos?

re 1. $\square$ Never - Nunca

re 2. $[$ Yes, for lmore than 1 month and less than 6 months - Sim, por mais de 1 mês e menos de 6 meses

re 3. $\square$ Yes, for less than 1 year - Sim, por menos de 1 ano

re 4. $\square$ Yes, for less than 2 years - Sim, por menos de 2 anos

re 5. $\square$ Yes, for less than 5 years - Sim, por menos de 5 anos

re 6. $\mathbb{C}$ Other:

If the answer to last question is YES, how many different times has the child lived in outside the US?/*Se a resposta para a pergunta anterior é AFIRMATIVA, por quantos períodos diferentes a criança já viveu fora dos Estados Unidos?

C Not applicable - Não se aplica

C Once - Uma vez

C Twice - Duas vezes

C Three - Três vezes

C More than five - Mais de cinco vezes

C Other:

What is the first language child learned?/*Qual foi a primeira língua que a criança aprendeu?

Does the child speak other languages, besides the first language?/*A criança fala outras línguas além da primeira língua?

re 1. $\Gamma$ Not applicable

re 2. $\Gamma \quad$ English

re 3. $\Gamma \quad$ Portuguese

re 4 ए $\square$ French

re 5. Г Spanish

re $6 . \Gamma$ Italian

re $7 . \Gamma$ Other: 
At what age was the child first exposed to his/her second language?/*Em que idade a criança foi exposta à sua segunda língua?

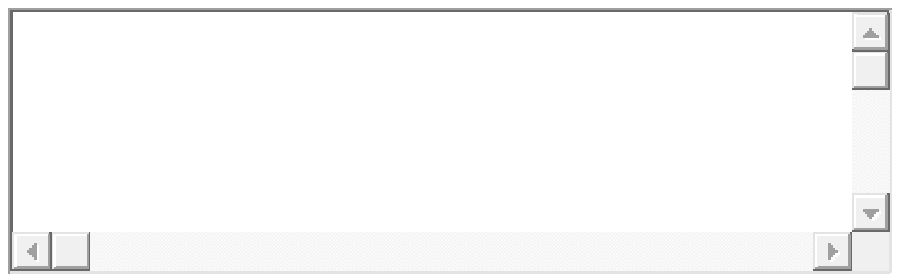

At what age did your child start going to school?/*Em que idade sua criança começou a ir para a escola?

Has your child ever gone to school in another country, other than the United States?/If the answer is YES, in which country? For how long?/*Sua criança já frequentou a escola em algum país além dos Estados unidos? Se a resposta for AFIRMATIVA, em qual país? Por quanto tempo?

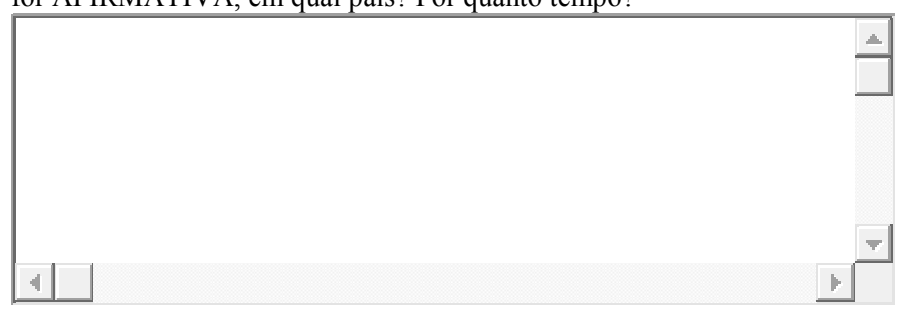

Has your child ever received formal education (i.e. language courses in a school) in any language other than his/her first language? If YES, please list which languages:/ *Sua criança já recebeu instrução formal (ex: cursos de língua) em alguma língua além da primeira língua? Se a resposta for afirmativa, por favor, faça uma lista das línguas

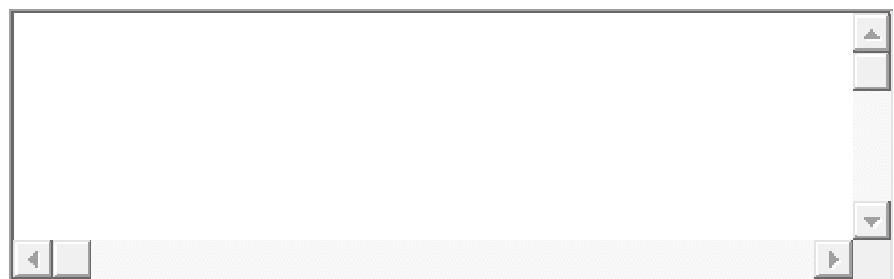

How many children live in the same household as your child? Are they all siblings?/*Quantas crianças vivem na mesma casa em que sua criança vive? Eles são todos irmãos?

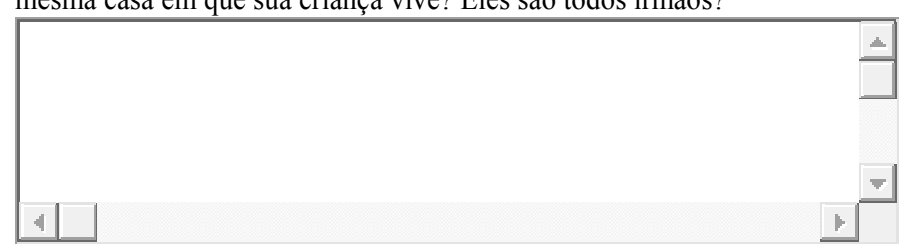

Would you say your child uses English:/*Você diria que seu filho fala inglês

Would you say your child uses Portuguese: *Você diria que seu filho fala português: 
Appendix 6-Randomized Sequences 
The order of sentences for each game follows a randomized sequence generated using RANDOM.ORG (http://www.random.org/). See http://www.random.org/randomness/ for a detailed discussion of pseudo-random and true random numbers. The random list of numbers is generated in http://www.random.org/sequences/, and sentences are organized in that sequence. Each game has its own randomized list, shown below:

\begin{tabular}{|c|c|}
\hline ORIGINAL & RANDOM. \\
\hline 1 & 4 \\
\hline 2 & 18 \\
\hline 3 & 23 \\
\hline 4 & 20 \\
\hline 5 & 9 \\
\hline 6 & 6 \\
\hline 7 & 24 \\
\hline 8 & 11 \\
\hline 9 & 5 \\
\hline 10 & 14 \\
\hline 11 & 13 \\
\hline 12 & 16 \\
\hline 13 & 28 \\
\hline 14 & 17 \\
\hline 15 & 12 \\
\hline 16 & 10 \\
\hline 17 & 21 \\
\hline 18 & 15 \\
\hline 19 & 8 \\
\hline 20 & 26 \\
\hline 21 & 22 \\
\hline 22 & 19 \\
\hline 23 & 3 \\
\hline 24 & 2 \\
\hline 25 & 30 \\
\hline 26 & 27 \\
\hline 27 & 7 \\
\hline 28 & 25 \\
\hline 29 & 1 \\
\hline 30 & 29 \\
\hline
\end{tabular}

Randomized Sequence ' $O U$-game'

Timestamp: 2012-06-04 10:52:41 UTC

\begin{tabular}{|c|c|}
\hline ORIGINAL & $\begin{array}{c}\text { RANDOM } \\
\text {. }\end{array}$ \\
\hline 1 & 14 \\
\hline 2 & 27 \\
\hline 3 & 4 \\
\hline 4 & 9 \\
\hline 5 & 28 \\
\hline 6 & 12 \\
\hline 7 & 8 \\
\hline 8 & 22 \\
\hline 9 & 23 \\
\hline 10 & 18 \\
\hline 11 & 11 \\
\hline 12 & 29 \\
\hline 13 & 16 \\
\hline 14 & 10 \\
\hline 15 & 3 \\
\hline 16 & 5 \\
\hline 17 & 17 \\
\hline 18 & 6 \\
\hline 19 & 26 \\
\hline 20 & 21 \\
\hline 21 & 19 \\
\hline 22 & 25 \\
\hline 23 & 13 \\
\hline 24 & 24 \\
\hline 25 & 7 \\
\hline 26 & 1 \\
\hline 27 & 2 \\
\hline 28 & 15 \\
\hline 29 & 30 \\
\hline 30 & 20 \\
\hline
\end{tabular}

Randomized Sequence "WH-Game" Timestamp: 2012-06-04 10:56:15 UTC 


\begin{tabular}{|c|c|}
\hline ORIGINAL & RANDOM. \\
\hline 1 & 33 \\
\hline 2 & 12 \\
\hline 3 & 13 \\
\hline 4 & 28 \\
\hline 5 & 24 \\
\hline 6 & 26 \\
\hline 7 & 16 \\
\hline 8 & 39 \\
\hline 9 & 10 \\
\hline 10 & 21 \\
\hline 11 & 22 \\
\hline 12 & 14 \\
\hline 13 & 9 \\
\hline 14 & 23 \\
\hline 15 & 11 \\
\hline 16 & 36 \\
\hline 17 & 19 \\
\hline 18 & 37 \\
\hline 19 & 17 \\
\hline 20 & 18 \\
\hline 21 & 38 \\
\hline 22 & 32 \\
\hline 23 & 31 \\
\hline 24 & 8 \\
\hline 25 & 29 \\
\hline 26 & 25 \\
\hline 27 & 1 \\
\hline 28 & 15 \\
\hline 29 & 20 \\
\hline 30 & 6 \\
\hline 31 & 2 \\
\hline 32 & 35 \\
\hline 33 & 5 \\
\hline 34 & 7 \\
\hline 35 & 34 \\
\hline 36 & 3 \\
\hline 37 & 40 \\
\hline 38 & 4 \\
\hline 39 & 27 \\
\hline 40 & 30 \\
\hline
\end{tabular}

Randomized Sequence Portuguese 'Puppet Game': Timestamp: 2012-06-04 11:03:05 UTC

\begin{tabular}{|c|c|}
\hline ORIGINAL & RANDOM. \\
\hline 1 & 17 \\
\hline 2 & 5 \\
\hline 3 & 37 \\
\hline 4 & 36 \\
\hline 5 & 33 \\
\hline 6 & 38 \\
\hline 7 & 22 \\
\hline 8 & 27 \\
\hline 9 & 18 \\
\hline 10 & 24 \\
\hline 11 & 14 \\
\hline 12 & 10 \\
\hline 13 & 30 \\
\hline 14 & 8 \\
\hline 15 & 21 \\
\hline 16 & 11 \\
\hline 17 & 23 \\
\hline 18 & 4 \\
\hline 19 & 1 \\
\hline 20 & 34 \\
\hline 21 & 12 \\
\hline 22 & 31 \\
\hline 23 & 35 \\
\hline 24 & 16 \\
\hline 25 & 20 \\
\hline 26 & 28 \\
\hline 27 & 13 \\
\hline 28 & 3 \\
\hline 29 & 2 \\
\hline 30 & 40 \\
\hline 31 & 19 \\
\hline 32 & 39 \\
\hline 33 & 26 \\
\hline 34 & 9 \\
\hline 35 & 15 \\
\hline 36 & 7 \\
\hline 37 & 32 \\
\hline 38 & 29 \\
\hline 39 & 25 \\
\hline 40 & 6 \\
\hline
\end{tabular}

Randomized Sequence English 'Puppet Game' Timestamp: 2012-06-04 11:07:00 UTC 